Maestría en Trabajo Social - 2013

\title{
Trayectoria Histórica del Instituto de la Vivienda de la Provincia de Buenos Aires en el período 1956-2009
}

\author{
Autora: Roxana Manes \\ Director: Eduardo López
}

Presentación: 4 de Noviembre de 2016 


\section{Dedicatoria}

Dedico esta investigación a todos aquellos que, de alguna forma, contribuyeron para que pueda realizar y llevar a cabo mi tesis. En particular a mi tutor Eduardo López. Y muy especialmente a: mi Padre, por su apoyo incondicional, a mi esposo y a mi hijita Marianela. 


\section{Agradecimientos}

Este trabajo está dedicado especialmente a mi tutor Eduardo López, quien me viene brindando su tiempo y conocimientos para el desarrollo del mismo desde la Carrera de Especialización en Políticas Sociales y ahora en la Maestría de Trabajo Social, también a Gabriela Marichelar quien nos acompañó en aquel momento, a los profesores y compañeros de la Carrera de la Maestría que me enriquecieron con sus enseñanzas y experiencias y a los compañeros del Instituto de la Vivienda que permitieron el acceso a información en especial del área Social, Biblioteca, Política Habitacional y Contable, a todos ellos muchas gracias por posibilitar este camino de aprendizaje. 


\section{Resumen}

El presente trabajo de investigación intenta profundizar el análisis realizado en mi trabajo final de la Especialización en Políticas Sociales, que se centró en la problemática de la efectivización del Derecho a la Vivienda (siempre entendido en su concepción ampliada dentro de la ciudad y las oportunidades y servicios que la ciudad ofrece) en la Provincia de Buenos Aires incorporando la dimensión histórica en términos de recuperar la trayectoria de las Políticas Habitacionales implementadas en los distintos períodos, explicada a través de su inserción en los diferentes modelos de acumulación económica nacionales: los modelos agroexportador, sustitutivo de importaciones y aperturista. El estudio gira en torno al Instituto de la Vivienda de la Provincia de Buenos Aires (IVBA), en tanto órgano responsable de la aplicación y la ejecución de la Política de Vivienda de Interés Social en la provincia y su trayectoria desde el año 1956 hasta 2009.

Palabras Clave: Derecho a la Vivienda - Derecho a la Ciudad - Efectivización del Derecho - Política Habitacional - Modelo de Acumulación

\section{Sommario}

La presente ricerca tenta di approfondire l'analisi che è stata svolta nel mio lavoro finale nell'ambito della Specializzazione in Politica sociale. Essa si concentra nell'individuazione dei problemi relativi all'effettivizzazione del diritto alla casa (inteso sempre nel suo concetto più ampio allinterno della città, delle opportunità e dei servizi che la stessa offre) nella Provincia di Buenos Aires. Per farlo traccia la dimensione storica in termini di recupero della traiettoria delle politiche abitative attuate in diversi periodi, descritta attraverso i modelli di accumulazione economica nazionale come: il modello agro-export, quello definito per sostituzione delle importazioni e quello aperto, per concentrarsi ora nella proposta della politica dell'Housing Institute della Provincia di Buenos Aires (IVBA) nel periodo che va dal1956 al 2009, dal momento che oggi è l'organo responsabile per l'implementazione e l'attuazione della politica abitazionale della Provincia.

Parole chiavi: diritto alla casa - diritto alla città - effettivizzazione della legge Politica Housing - Modello di accumulazione. 


$\begin{array}{ll}\text { Abreviaturas } & \\ \text { ATEPAM } & \text { Asistencia Técnica Esfuerzo Propio y Ayuda Mutua } \\ \text { CEV } & \text { Asociación de Vivienda Económica } \\ \text { IVBA } & \text { Centro Experimental de la Vivienda Económica } \\ & \text { Instituto de la Vivienda de la Provincia de Buenos } \\ \text { FONAVI } & \text { Aires } \\ \text { FOPROVI } & \text { Fondo Nacional de Vivienda } \\ \text { IPV } & \text { Instituto Provincial de la Vivienda } \\ \text { MOSP } & \text { Ministerio de Obras y Servicios Públicos } \\ \text { PEVE } & \text { Programa Erradicación de Villas de Emergencia } \\ \text { PYM } & \text { Provincia y Municipios } \\ \text { SEHAS } & \text { Servicio Habitacional y de Acción Social AVE } \\ \text { SVOA } & \text { Secretaria de Vivienda y Ordenamiento Ambiental }\end{array}$




\section{ÍNDICE}

Contenido

Página

Introducción.

10-13

Antecedentes y Justificación/Objetivos General/ Específicos.

$10-12$

Aspectos Metodológicos.

Capítulo I: Marco Teórico.

14-25

Definición de Conceptos Claves.

14-15

Las Políticas Estatales-Sociales.

Las Políticas Habitacionales.

19-20

El Derecho a la Vivienda y la Ciudad.

20-24

Modelos de Gestión para el Hábitat Social.

24-25

Capítulo II: Antecedentes.

26-35

Antecedentes Nacionales de la Política Habitacional.

Antecedentes Provinciales de la Política Habitacional:

El Instituto de la Vivienda Obrera.

$27-35$

\section{Capítulo III: La Política Habitacional del Desarrollismo y el}

Nacimiento del Instituto de la Vivienda de la Prov. Bs.As. (IVBA) 36-56

III.1- La Política Habitacional del Modelo Sustitutivo de Importaciones

en su etapa Desarrollista (1955-1976).

$36-42$

Contextualización del Período.

Descripción de la Política Habitacional del período:

Crecimiento de la Región Metropolitana de Bs. As.

III.2.-Creación y Gestión del IVBA.

43-56

Creación del IVBA (marco normativo).

43-46

Operatorias de Vivienda del período:

46-56

Barrios Obreros.

46-47

Barrios Arquitectura

47

Acción Cooperativa.

48

Sistema Asistencia Técnica Esfuerzo Propio y Ayuda Mutua-ATEPAM.

48-51

Provincia y Municipios (PYM).

51-53 
Entidades Intermedias Decreto 3201/70. 53

Entidades Intermedias ATEPAM x Coparticipación. 53

Entidades Intermedias Plan Federal Banco Hipotecario Nacional. 53

Plan Erradicación de Viviendas Precarias PEVEP. 54-55

Conclusiones de la Gestión del IVBA del Período. 55-56

\section{Capítulo IV: EI IVBA y la Política Habitacional}

en el Modelo Aperturista Autoritario (1976-1983).

IV.1.-La Política Habitacional de la Etapa Aperturista Autoritaria. 57-63

Contextualización de la etapa. $\quad$ 57-59

Descripción de la Política Habitacional de la etapa. 59-60

Estabilización y Transición de la Región Metropolitana

de Buenos Aires. $\quad 60-63$

IV.2.- Gestión del IVBA en el Modelo Aperturista en la

Etapa Autoritaria. $\quad$ 63-67

Operatorias de Vivienda de la Etapa: $\quad$ 64-67

Alborada. $\quad 65$

FONAVI. $\quad$ 65-66

FOPROVI. $\quad 66$

Conclusiones de la Gestión del IVBA de la Etapa.

\section{Capítulo V: EI IVBA y la Política Habitacional}

en el Modelo Aperturista Democrático (1983-2003). 68-99

V.1. La Política Habitacional de la Etapa Aperturista Democrática. $\quad$ 68-74

$\begin{array}{lr}\text { Contextualización de la etapa. } & 68-70\end{array}$

Descripción de la Política Habitacional de la etapa: $\quad$ 71-72

Inserción Global de la Región Metropolitana de Bs. As. 72-74

V.2.- Gestión del IVBA en el Modelo Aperturista

en la Etapa Democrática. $\quad$ 74-99

Operatorias de Vivienda Sub-Etapa (1983-1992): $\quad$ 82-87

Autogestión Constructiva. $\quad$ 83-84 
ProCasa.

ProCasa-Solidaridad-Vuelta al Pago-ProTecho-Reconstrucción de barrios. 84-85

Rural.

$85-86$

Conclusiones de la gestión del IVBA de la sub-etapa.

$86-87$

Operatorias de Vivienda Sub-Etapa (1992-2003):

$87-99$

Bonaerense I: Abuelos-Novios.

$87-90$

Bonaerense II: Solidaridad y sus subprogramas.

91

Bonaerense III: Financiamiento Compartido.

92

Bonaerense IV: Emergencia Habitacional.

93-94

Conclusiones de la gestión del IVBA de la sub-etapa.

94-99

\section{Capítulo VI: EI IVBA y la Política Habitacional en la Transición al Modelo Productivo (2003-2009).}

100-129

VI.1-Política Habitacional del Período.

$100-104$

Contextualización del período.

$100-101$

Descripción de la Política Habitacional del período.

101-104

VI.2-Gestión del IVBA en el Modelo Aperturista en la Transición

al Modelo Productivo.

$104-129$

Operatorias de Vivienda del Período (Federales):

$104-116$

Federales.

104-107

Federal Construcción con Municipios.

107

Federal Urbanización de Villas y Asentamientos Precarios.

107-108

Federal Mejor Vivir.

109-110

Federal Integración Comunitaria.

111-112

Federal Reactivación.

Evaluación de los Federales

$113-116$

Operatorias de Vivienda (Provinciales).

116-119

Nuestra Casa. / Policía Comunal y Distrital.

116

Solidaridad. /Solidaridad con Municipios.

Solidaridad con Entidades sin fines de Lucro.

Vivienda Rural.

Vivienda con criterios Bioclimáticos.

Lotes con Servicios. 
Buenos Aires Hogar.

$120-121$

Conclusiones de la gestión del IVBA del período.

$122-123$

Conclusiones comparativas de los períodos.

123-129

Conclusiones.

130-135

Anexo 1: Estructura Organizacional del IVBA.

136-157

Anexo 2: Fotos.

158-162

Bibliografía.

163-167 


\section{Introducción}

El propósito del presente trabajo de investigación es profundizar el análisis realizado en mi trabajo final de la Especialización en Políticas Sociales, que se centró en la problemática de la efectivización del Derecho a la Vivienda en la Provincia de Buenos Aires. Parto de entender este derecho desde su concepción ampliada dentro de la ciudad incluyendo las oportunidades y servicios que ésta ofrece. Para abordar la efectivización del derecho en la Provincia de Buenos Aires centro el estudio en la gestión del Instituto de la Vivienda (I.V.B.A.), órgano específico de implementación de la política de vivienda. Para abarcar la complejidad de la gestión incorporo la dimensión histórica en términos de recuperar la trayectoria de las Políticas Habitacionales implementadas en los diferentes períodos, explicada a través de su relación con los diferentes modelos de acumulación económica en Argentina. Mi objetivo es poder comprender los avances - o retrocesos - que estas políticas del Estado implicaron en la efectivización del derecho.

Con el fin de profundizar el análisis de la Política Habitacional en la provincia de Buenos Aires me centraré en el ámbito del I.V.B.A. y su trayectoria desde su creación en 1956 hasta el año 2009. La fecha límite está dada por la necesidad de hacer un recorte y la disponibilidad de los datos.

El particular interés por esta problemática está puesto en la inaccesibilidad a los servicios habitacionales para una gran cantidad de habitantes de nuestra provincia y en la importancia del Instituto de la Vivienda en la posibilidad de resolverla. Según el último Censo Nacional de Población, Hogares y Vivienda de 2010, la cantidad de habitantes de la provincia de Buenos Aires es de 15.594.428 y, cuyo déficit habitacional provincial es de 1.586 .998 viviendas (correspondiendo 1.341 .461 a viviendas recuperables, 65.645 a viviendas irrecuperables y 179.892 a hogares hacinados) dicho déficit representa el $10,18 \%$ de la población provincial. Además, teniendo en cuenta que a nivel país la población de Argentina es de 40.117.096 habitantes y su déficit habitacional total de 3.095.312 hogares, la provincia de Buenos Aires representa el $51,27 \%$ del total nacional siendo así la de mayor déficit habitacional.

- Para desarrollar y analizar la trayectoria histórica del IVBA, la caracterización de la política habitacional, los avances y / o retrocesos en la efectivización del Derecho a la Vivienda, realizaré la siguiente división en períodos/ etapas basada en los modelos de 
acumulación económica argentina; los que están relacionados con mi trabajo de investigación anterior sobre la Política Social Habitacional en la Provincia de Buenos Aires.

- El período 1955-1976 coincidente con el Modelo de Acumulación Económica Sustitutivo de Importaciones en su etapa Desarrollista el cual forma parte de un período mayor iniciado en 1930, y en el que desde 1945 a 1955 se produce la Etapa Justicialista.

- La Etapa Autoritaria 1976-1983 en convergencia con el Modelo de Acumulación Económica Aperturista.

- La Etapa Democrática 1983- 2003 correspondiente también al Modelo de Acumulación Aperturista: a su vez dividido en subetapas: centralizada (1983-1992) y descentralizada (1992-2003).

- El período 2003-2009 coincidente con el Modelo de Acumulación Económica Aperturista en transición al Modelo Productivo.

Este trabajo está organizado en seis capítulos. El primer capítulo describe el marco conceptual. El segundo se refiere a los antecedentes fundacionales del IVBA. Los capítulos tercero, cuarto, quinto y sexto contienen dos apartados cada uno: en el primero se presenta la Política Habitacional de la provincia de Buenos Aires, conforme a los momentos históricos que corresponden a los diferentes modelos de acumulación de la economía argentina. El segundo apartado se refiere, específicamente, a la gestión del IVBA durante los mismos. Así, el capítulo tres habla de la Política Habitacional y la Gestión del IVBA correspondiente al Modelo Sustitutivo de Importaciones en su etapa Desarrollista durante el período comprendido entre 1955-1976. El capítulo cuarto trata sobre la política habitacional y la gestión del IVBA en la Etapa Autoritaria del Modelo Aperturista 1976-1983. El capítulo cinco se refiere a la Etapa Democrática 1983-2003 también del Modelo Aperturista, a su vez dividido en subetapas: centralizada (19831992) y descentralizada (1992-2003). El capítulo seis trata sobre la Política Habitacional y gestión del IVBA en el Modelo Aperturista en la transición al Modelo Productivo durante los años 2003-2009. Por último, se encuentran las conclusiones, anexos y bibliografía.

El objetivo general de este trabajo es analizar la gestión del Instituto de la Vivienda de la provincia de Buenos Aires y su política habitacional, desde una perspectiva histórica a partir de 1956 hasta 2009; en términos de avances y retrocesos en la efectivización del Derecho a la Vivienda. 
Para ello se propone la consecución de los siguientes objetivos específicos:

- Describir y analizar los antecedentes históricos del IVBA.

- Relacionar el desarrollo institucional del IVBA con la política habitacional y con los modelos de acumulación vigentes en la política económica nacional.

- Analizar las funciones, la autarquía, las operatorias / programas que permitan dar cuenta de su vinculación con la política habitacional de cada etapa.

- Establecer los avances y retrocesos en el acceso / efectivización del derecho a la vivienda que permitió el accionar (gestión) del IVBA.

En cuanto a los aspectos metodológicos, este estudio exploratorio se desarrolla especialmente - a partir del análisis de fuentes documentales como publicaciones oficiales (Encuesta Permanente de Hogares y Censo Nacional de Población, Hogares y Vivienda del 2010 del Instituto Nacional de Estadística y Censos - INDEC), textos, periódicos y revistas locales en formato papel (impresas) y digital (consultadas a través de páginas de internet); estas fuentes secundarias proveen de información retrospectiva y permiten abordar el tema con cierta amplitud y estructura aportando datos tanto cualitativos como cuantitativos.

Otros tipos de fuentes utilizadas son las de tipo normativo - que provienen de entes oficiales - como la Constitución Nacional y Provincial, las leyes, los decretos, las resoluciones ministeriales e institucionales, las disposiciones, los planes, los programas, los proyectos, los tratados, los acuerdos internacionales y los textos políticos análogos. Se consultaron las siguientes leyes: Constitución Nacional y Provincial, Declaración Universal de los Derechos Humanos, Pacto Internacional de Derechos Sociales, Económicos y Culturales, Ley 4551/37 de creación del Instituto de la Vivienda Obrera, Ley 5396/48 general de vivienda, Ley 469/56 de creación del IVBA y su modificatoria 9573/80 de creación del Fondo Provincial de Vivienda (FOPROVI), Ley 21581/77 del Fondo Nacional de Vivienda (FONAVI), Ley 8912/77 de Uso del Suelo y actual Ley de Acceso Justo al Hábitat 14449/13, Ley 24130/92 de Federación del FONAVI, Ley 24464/95 de Creación del Sistema Federal de Vivienda, Ley 11663/95 de Adhesión del IVBA y su decreto reglamentario 187/96, entre otras leyes, decretos y resoluciones que dan marco a las operatorias y programas habitacionales, así como también las publicaciones oficiales de datos del INDEC, entre otras. 
Otro tipo de fuente fue la bibliografía especializada en el tema de los referentes actuales tanto académicos como políticos, el recorrido por los textos, las publicaciones, los archivos de páginas web y la asistencia a conferencias.

Debido a que me desempeño laboralmente en el IVBA es posible el acceso a su Centro de Documentación y Biblioteca, para la obtención de material documental público, como la compilación de Memorias desde 1956 a 1999 elaborada por la arquitecta Igarzabal (quien se desempeñó en la Jefatura del Departamento de Control de Gestión de la Dirección de Política Habitacional de dicho Instituto).

La utilización de las fuentes mencionadas se orienta a obtener la información necesaria para alcanzar los objetivos específicos de describir y analizar los antecedentes históricos del IVBA y parte de la descripción y del análisis de la trayectoria histórica institucional del IVBA desde 1956 a 1999, sus funciones, autarquía, y sobre todo las operatorias / programas que permiten dar cuenta de su vinculación con la política habitacional y los avances y retrocesos en el acceso / efectivización del derecho a la vivienda.

El objetivo específico de describir y analizar la trayectoria histórica institucional del IVBA desde 2000 a 2009 se completa con el uso de información publicada por la Dirección de Política Habitacional - en la página de internet del IVBA correspondiente a dichos años - sobre las operatorias de vivienda.

También se incorpora un relevamiento de información de fuentes primarias como entrevistas a personal del I.V.B.A. que permiten analizar la información reunida y le dan voz a lo que no está dicho o escrito en la información oficial. 


\section{Capítulo I}

\section{Marco teórico}

\section{Definición de conceptos claves}

Se parte del supuesto de que existe una tensión en el ejercicio de la ciudadanía - dada por la distancia que hay entre los derechos postulados desde las leyes (Constitución Nacional y Provincial, adhesión a la Declaración Universal de los Derechos Humanos, al Pacto Internacional de Derechos Sociales, Económicos y Culturales) y su efectivización - a la que no todos los habitantes alcanzan, verificándose grandes desigualdades, donde el Estado interviene de distintas maneras acercándose o alejándose del derecho (según se posibilite efectivamente o no el acceso a la igualdad).

Se entiende a la vivienda desde su concepción ampliada dentro de la ciudad y en relación a las oportunidades y servicios que la ciudad ofrece. Pues se utiliza el término vivienda digna y adecuada tomado de la Declaración Universal de Derechos Humanos, el Pacto Internacional de Derechos Sociales Económicos y Culturales, y la Observación General $\mathrm{N}^{\circ} 4$ de su Comité, que la define así cuando cumple los siguientes estándares: seguridad jurídica de la tenencia, disponibilidad de servicios, materiales, facilidades e infraestructura, gastos soportables, habitabilidad, asequibilidad, lugar y adecuación cultural.

El Derecho a la Vivienda digna y adecuada tiene consecuencia directa sobre la vida de las personas, sus condiciones en el proceso de reproducción social, el acceso a las oportunidades educativas, en la salud, en el transporte y laborales, y la centralidad entre otros aspectos; por lo que su falta de efectivización implica dificultades para materializar otros derechos (al trabajo, la alimentación, la salud, la educación, y el transporte). Estas desigualdades se evidencian en el déficit habitacional, se visibilizan en el aumento y extensión de asentamientos informales y en la pobreza; involucrando, también, la desigualdad de género (que excede el alcance del presente trabajo), ya que se verifican gran cantidad de hogares pobres cuya jefa de hogar es la mujer, o se trata de mujeres solas frente al hogar. 
De esta forma, la vulneración del Derecho a la Vivienda pone en debate a la Política Habitacional implementada, ya que es tratada - desde hace tiempo - por autores de distintos ámbitos académicos, como: Oscar Yujnovsky (1994) que entiende a la política habitacional como el producto de una sociedad determinada con cierta organización social y relaciones de poder; y a la vivienda en su concepción ampliada de servicios habitacionales; Raúl Fernández Wagner (2008) que concibe a la política habitacional como una construcción jurídico-institucional en función de derechos (de distinta generación en relación a su ejercicio) y de niveles de descentralización hacia la población involucrada.

Para comenzar, cabe definir a las Políticas Estatales, y dentro de éstas a las Políticas Sociales, a su vez dentro de estas últimas a las Políticas Habitacionales, dada su relación con el tema de investigación ya que la articulación entre las mismas permite enmarcar el presente trabajo:

\section{Las Políticas Estatales-Sociales:}

Las políticas estatales ${ }^{1}$ son definidas por Oszlak y O’Donnell (1976) como las cuestiones socialmente problematizadas que se colocan como agenda de Estado, y cumplen un proceso de masificación con tres requisitos, como señalan Cobb y Elder (1983), ellos son: 1) ser objeto de amplia atención y conocimiento del público; 2) que buena parte de éste considere que se requiere algún tipo de acción; 3) que esa acción sea vista como competencia de alguna entidad gubernamental.

Conforme a la definición anterior, Danani (1995) define a las políticas sociales como un tipo de políticas estatales y considera dentro de éstas, como lo hacen Oszlak y O’Donnell (1976), a las acciones y omisiones del Estado y concibe a dichas políticas sociales como constitutivas del régimen social de acumulación (Nun, 1987; Gordon et Alii, 1986) y encuentra su especificidad en el hecho de orientarse de manera directa a las condiciones de vida (y de reproducción de la vida) de distintos sectores y grupos sociales, operando especialmente en el momento de distribución secundaria del ingreso (es decir, no en la distribución del ingreso directamente derivada del proceso de producción, por la vía de retribución de los factores, sino por mecanismos de

\footnotetext{
${ }^{1}$ En el presente trabajo, el término de Políticas Estatales o Públicas son utilizados indistintamente.
} 
redistribución que se le superponen); cumplen una función reguladora de las condiciones de venta y uso de la fuerza del trabajo (Cortés y Marshall, 1993), contribuyendo así a la construcción de un orden como totalidad, así lo dice Lechner (1981), simultáneamente económico, político y sociocultural, y son producto de procesos en los que está en juego la generalidad del orden.

Danani (1995) sostiene que las políticas sociales no son las únicas intervenciones sociales del Estado, también lo es la política laboral (entre otras) pero ésta opera de manera directa en la relación capital-trabajo (distribución primaria del ingreso), ni tampoco son las únicas intervenciones sociales existentes ya que un conjunto de instituciones y actores no estatales desarrollan intervenciones sociales; y acuerda con Coraggio (1994) en la reconstrucción de un espacio conceptual e históricamente unitario entre política económica y política social.

Para Danani (1995) los conceptos de Esping-Andersen (1993) deben considerarse en el abordaje de los estudios sobre política social, ya que en el marco del estado de bienestar redefine el concepto de derechos sociales según su capacidad para la desmercantilización, es decir, de qué manera el acceso a los derechos se autonomiza o por el contrario se hace más dependiente de las fuerzas del mercado.

Danani (1995) analiza las políticas según la calidad de los derechos sociales, de la estratificación social a que dan lugar y de los diferentes arreglos cualitativos entre el Estado, el mercado y la familia que implementan, centrando el análisis en la lógica que articula a los actores intervinientes y su trayectoria global; entiéndase como procesos que recorren diversos momentos y niveles, y que involucran a distintos sujetos y agentes sociales.

También Danani (1995) considera necesario, para el abordaje de las Políticas Sociales, considerar al Régimen Social de Acumulación (recreado por Nun y Portantiero, 1987) que lo define como el conjunto complejo de instituciones, regulaciones (para normatizar los espacios existentes) y prácticas que en un determinado momento inciden en la acumulación de capital; y entiende que las políticas sociales participan de los procesos de constitución de las clases sociales, ya que se dirigen / intervienen en el proceso de reproducción social por medio del cual las clases sociales mismas llegan a existir. 
Profundizando desde los aportes de la perspectiva de totalidad, las políticas sociales cumplen funciones básicas con una doble lógica de consenso y coerción: una función social (prestación de servicios y transferencia de recursos o distribución), una función económica (reducción de los costos de producción y reproducción de la fuerza de trabajo y su sociabilización para propiciar la acumulación del capital) y una función política (la disminución de la insatisfacción popular, tendiente a la desmovilización y al control social, logrando así la legitimación y aceptación del Estado y del sistema político económico). A ellas cabe agregar la función cultural como propone Corbalán (2002) donde se ejerce una dominación simbólica como estrategia de regulación y control (por la vía pacífica de la persuasión) donde principios provenientes de particulares se constituyen en principios reguladores de las políticas del Estado, como es el caso de los procesos recomendados por los organismos de crédito (Banco Mundial y FMI) a los Estados a través de los métodos de ajuste estructural que promueven a cambio de sus financiamientos y que por medio de sus condicionalidades se constituyen en principios de acción y regulación de la política económica y financiera del Estado; valiéndose de estrategias coactivas y también de otras vinculadas al plano de la violencia simbólica (persuasión) para su adopción.

Para Corbalán (2002) tales mecanismos persuasivos están asociados a: principios hegemónicos de visión, procesos de enseñanza del aprendizaje (asentados en la asimetría entre el que brinda y el que recibe la información, y la incorporación de reglas prácticas como procedimientos y normas por parte del Estado para recibir el crédito), el saber de expertos y especialistas (a través de la racionalización y el recambio de agentes estatales por agentes con perfil más acorde a los lineamientos propuestos para la reforma de las políticas), consultores y asesoramiento técnico, como así también el cumplimiento de los ciclos de un proyecto donde se deja abierta la posibilidad de punición al Estado que los incumpla; y por último la prensa escrita y otros recursos mediáticos como el cine.

Para ampliar, Therborn (1987) habla de cómo la ideología modela la forma en que los seres humanos viven sus vidas en un contexto específico e identifica seis principales tipos de mecanismos ideológicos de dominación (según los efectos que producen):

- la adaptación: vista como conformidad que permite que los dominadores sean obedecidos, donde las personas aun con actitudes desobedientes con los dominadores no están dispuestas a combatirlos efectivamente (consumo), 
- el sentido de la inevitabilidad: refiere a la obediencia por ignorancia de cualquier tipo de alternativa,

- el sentido de la representación: se da cuando se considera que los dominadores dominan a favor de los dominados (sensación de semejanza o pertenencia),

- la deferencia: apunta a concebir a quienes dominan como una casta superior pero puede implicar también el miedo (clientelismo),

- el miedo: donde la fuerza domina con el miedo y coloca en situaciones extremas como elegir entre la resistencia y la muerte o la obediencia y la vida,

- la resignación: una visión pesimista arraigada sobre la imposibilidad práctica de una alternativa mejor.

Analizar las políticas sociales desde una perspectiva de totalidad aporta a aprehender conjuntamente los momentos de reproducción y de distribución como elementos constitutivos de una totalidad y a considerar las inseparables conexiones existentes entre economía y política, pues de esta forma se puede captar la complejidad del fenómeno social si se comprenden sus vínculos con la economía y con la política, sin descuidar ni una ni otra dimensión de la totalidad social.

Autores como Iamamoto (2008) y Netto (2009) aportan a la reflexión sobre la tensión por los derechos, señalando -desde la constitución del estado capitalista contemporáneola contradicción dada por el liberalismo económico y político donde la igualdad es en términos abstractos y no concretos, a la cual el Estado, mediante sus políticas le da respuestas de forma fragmentada: por un lado a través de las políticas sociales y por el otro a través de las políticas económicas. Según la correlación de fuerzas de las clases sociales, siempre dentro del Estado Capitalista, dicha tensión se acerca más al derecho o más a la desigualdad y cuando se aproxima más al derecho es a través de la intervención de la política social universal y no fragmentada; además de otras posibles cuestiones y estrategias.

Las políticas sociales varían dependiendo de las concepciones que se tengan sobre las principales significaciones y valoraciones que deben orientarlas, su forma, el rol del Estado y el de la sociedad, es así como las situaciones que afectan a la población se problematizan con procesos que tienen que ver con las relaciones de poder e influencia de los grupos y sectores y sus posibilidades de colocar temas en la agenda pública, mediante las mediaciones propias de la institucionalidad política, y de los medios de 
comunicación, entre otros. De ahí la fuerza de la violencia simbólica que plantea Corbalán con los mecanismos persuasivos.

\section{Las Políticas Habitacionales:}

Por lo expuesto la Política Habitacional es parte de la Política Social y esta última de la estatal. De este modo posee las características propias de la política social que, según enuncia Zambrini (2010), responde al entramado social, a relaciones de fuerza y poder de distintos agentes individuales y colectivos en cada momento histórico; en donde el Estado y el derecho (no el derecho en sí mismo sino por estar encarnado en sujetos o agentes que representan intereses diferentes) mantienen relaciones de conflicto. Así, los cambios en la estructura social se dan en el marco de una disputa por el poder entre bloques sociales, clases o fracciones de clase en pugna como resultados de una determinada correlación de fuerzas, entendida como el equilibrio provisorio de poder entre dichos bloques sociales enfrentados.

En el mismo sentido, para Zambrini (2010), el abordaje de las políticas sociales no puede soslayar la dimensión histórica y concibe - como Golbert (2004)- que las mismas no se formulan ni ejecutan en el vacío, sino que responden a un entramado social, político e institucional determinado. Por lo tanto, la política social y la estructura social tienen una historicidad y una cultura. Se podría decir que la estructura social entendida como los elementos más permanentes que hacen a una organización social genera formas de hacer y pensar, lo cual varía las formas del Estado (democrático o autoritario) a lo largo de la historia, y por lo tanto cambia la estrategia e intervención del mismo (modelo de acumulación).

De lo dicho se desprende que las luchas entre bloques, clases o fracciones de clase sociales, configuran un determinado modelo de acumulación y una particular estructura social; ya que cuando un bloque social tiene la fuerza suficiente, impone un modelo de acumulación acorde a sus intereses.

El Modelo de Acumulación para Torrado (1991) es una estrategia de acción (objetivos, proyectos y prácticas políticas) relativa a los actores fundamentales que asegura la acumulación capitalista: cómo se genera, cuáles son los elementos que condicionan su dinamismo, cómo se distribuye el excedente y que son dominantes en 
una sociedad concreta, en un momento histórico determinado. Cada modelo de acumulación da cuenta de una determinada estrategia de los bloques sociales que lo impulsan, entendiendo a ésta - según Giménez (1986) - como el arte de elaborar decisiones conformes a la promoción o defensa de un interés, tomando en cuenta el sistema de intereses confrontados y las posibilidades de decisiones y defensa de los demás intereses.

Así, Giménez (1986) distingue entre el tipo de Estado que responde a la lógica de un determinado modo de producción (Estado capitalista) y las formas que puede adoptar un mismo tipo de Estado sin que se modifique su naturaleza, de manera que dichas formas plantean un modo de articulación y relación específica entre distintas instituciones y prácticas de un Estado.

Por su parte, Fernández Wagner (2008) concibe la Política Habitacional o de Vivienda, incluida en la dimensión de las Políticas Sociales de provisión pública de infraestructura social; constituyendo a la vivienda social en el dispositivo político y económico, que permite dar respuestas de política pública a partir del reconocimiento del Derecho a la Vivienda.

\section{EI Derecho a la Vivienda y a la Ciudad:}

El Derecho a la vivienda se amplía con el Derecho a la Ciudad que según Harvey (2008) es mucho más que la libertad individual de acceder a los recursos urbanos, sino que se trata del derecho a cambiarnos a nosotros mismos modificando la ciudad; siendo un derecho común antes que individual, ya que esta transformación depende, inevitablemente, del ejercicio de un poder colectivo para remodelar los procesos de urbanización.

Mathivet (2009) reconoce la aparición del término Derecho a la Ciudad en 1968, cuando el francés Henri Lefebvre escribió sobre el impacto negativo sufrido por las ciudades en los países de economía capitalista (con la privatización de los espacios urbanos, el predominio de industrias y espacios mercantiles) y propuso una nueva perspectiva política denominada Derecho a la Ciudad para restaurar el sentido de ciudad, instaurar la posibilidad del buen vivir para todos, y hacer de la ciudad el escenario de encuentro para la construcción de la vida colectiva. 
La autora toma a Jordi Borja, para quien la ciudad es un espacio político, en donde es posible la expresión de las voluntades colectivas (tanto de solidaridad como de conflicto). El derecho a la ciudad es la posibilidad de construir una ciudad en la que se pueda vivir dignamente, reconocerse como parte de ella, y en la que se posibilite la distribución equitativa de los diferentes tipos de recursos como: trabajo, salud, educación, vivienda, y recursos simbólicos como la participación y el acceso a la información, entre otros; a través de un triple proceso: cultural, social (de movilización ciudadana) y político institucional para formalizarlos en políticas que los hagan efectivos.

Dice que la reivindicación de la posibilidad necesaria de crear otra ciudad se basa en los derechos humanos, y más precisamente en los Derechos Económicos, Sociales y Culturales (DESC); donde el fenómeno de la ciudad está analizado y pensado por medio de los conceptos de ciudadanía y espacio público con una visión integral e interdependiente de los derechos humanos para lograr la meta de recuperar la ciudad para todos sus habitantes. Sin embargo, es importante aclarar que el derecho a la ciudad no es un derecho más, es el derecho a hacer cumplir los derechos que ya existen formalmente. Por eso el derecho a la ciudad se basa en una dinámica de proceso y de conquista, en el cual los movimientos sociales son el motor para lograr su cumplimiento.

Un paso fundamental ha sido la elaboración de la Carta Mundial por el Derecho a la Ciudad articulada por Hábitat International Coalition (HIC) de la que participaron un conjunto de movimientos populares, organizaciones no gubernamentales, asociaciones profesionales, foros y redes nacionales e internacionales de la sociedad civil, comprometidas con las luchas sociales por ciudades justas, democráticas, humanas y sustentables.

Mathivet (2009) resume dicha Carta en tres ejes fundamentales:

- el ejercicio pleno de la ciudadanía, es decir el ejercicio de todos los derechos humanos que aseguran el bienestar colectivo de los habitantes y la producción y gestión social del hábitat;

- la gestión democrática de la ciudad, a través de la participación de la sociedad de forma directa y participativa, en el planeamiento y gobierno de las ciudades, 
fortaleciendo las administraciones públicas a escala local, así como a las organizaciones sociales;

- la función social de la propiedad y de la ciudad, siendo predominante el bien común sobre el derecho individual de propiedad, lo que implica el uso socialmente justo y ambientalmente sustentable del espacio urbano.

La ciudadanía, en la visión clásica de Marshall (1992) es un estatus asignado a todos aquellos que son miembros plenos de una comunidad, y todos los que posean dicho estatus son iguales con respecto a derechos y deberes, libertades y restricciones, poderes y responsabilidades. Según Sojo (2002), la ciudadanía - más que una práctica consolidada - es una aspiración social en una región donde los déficit de ejercicio pleno de ella son severos, más agudos para mujeres y etnias, pero generales.

Para Fernández Wagner (2008) toda política pública implica una construcción institucional, que regula y organiza la distribución de recursos en la población, directa o indirectamente, y en el caso de la política habitacional, dicha construcción institucional se divide en dos dimensiones:

- su construcción jurídico-institucional en función de derechos: mediante el desarrollo de un conjunto de instrumentos jurídicos asociados a los derechos de ciudadanía (los límites a la propiedad y la renta), y otro conjunto de instrumentos de gestión (disposiciones, normas) vinculados con la distribución de los recursos para consolidar un sistema de protección social, de redistribución de los bienes y servicios esenciales para la vida, ya no sólo por principios básicos de igualdad social (teniendo en cuenta los factores estructurales de desigualdad: propiedad privada y ganancias sin límites) sino al menos con fines de equilibrio funcional del sistema económico y político nacional.

- la construcción institucional de los niveles de descentralización (transferencia de poder y recursos) de la misma hacia la población involucrada; destacándose el diseño del modo en que los diferentes niveles del Estado y la sociedad organizada tienen injerencias, responsabilidades y competencias en la ejecución de la política en el territorio.

En términos generales en el problema habitacional intervienen varios aspectos:

- demográficos: crecimiento vegetativo de la población y migraciones, 
- componentes físicos de la vivienda y su entorno: diseño de la vivienda, habitabilidad de la construcción, situación sanitaria, condiciones del lugar de emplazamiento, y medios físicos de integración social (caminos, equipamiento educativo y sanitario),

- componentes sociales: densidad habitacional (relación entre el número de habitantes y el espacio disponible),

- componentes económicos (inaccesibilidad al suelo urbano por la especulación),

- legales y normativos,

- políticos y programáticos.

Para Yujnovsky (1984) al analizar la política habitacional hay que tener en cuenta que ésta se produce en una sociedad determinada con cierta organización social y relaciones de poder, y que el concepto de vivienda debe ampliarse y referirse a los servicios habitacionales (que tienen que dar satisfacción a necesidades primarias: albergue, refugio, protección ambiental, espacio, vida de relación, privacidad, seguridad, identidad, accesibilidad física, etc.) proporcionados en cierto período en una configuración espacial urbana, en un medio ambiente de una sociedad determinada; que es parte de un sistema social cuya característica en la sociedad argentina es un medio económico donde predominan las relaciones de producción capitalistas, y donde el sector de la vivienda es parte de un proceso de acumulación que toma a la vivienda como mercancía e intervienen los mercados de tierra, construcción, materiales, y servicios financieros, entre otros; los que funcionan de modo imperfecto priorizando el derecho individual, donde la accesibilidad a dichos mercados no es igualitaria para toda la población y depende del poder de compra (según nivel de ingreso y factores culturales) que le permite a determinados sectores sociales sostener la demanda económica de servicios habitacionales, lo cual tiene una evidencia empírica en la distribución territorial.

Así, Yujnovsky concluye que ante esta situación el Estado debe intervenir para una reforma social y mejorar la realidad de los sectores populares. Por lo tanto, es necesario considerar la dimensión socio-económica, las ideas y la política; y reconocer el modelo hegemónico existente -o las fuerzas sociales que se intentan imponer - cuyos objetivos son la reproducción del sistema de dominación o lograr una transformación democrática en una coyuntura determinada; por lo cual toda intervención del Estado en el sistema económico, directa o indirectamente, sus políticas y profundidad en las reformas 
dependen de en qué medida los sectores populares han acumulado fuerza en la época que se considera y están representados en el Estado.

El Servicio Habitacional y de Acción Social (SEHAS) de la Asociación de Vivienda Económica (AVE) plantea tres modelos de gestión para el Hábitat Social:

- Modelo Tradicional: el ente del Estado que se ocupa de la vivienda concentra las actividades y la toma de decisiones en relación a las programaciones: realiza la programación, contrata a las empresas constructoras que ejecutan las viviendas, controla a dichas empresas y finalmente aparece el destinatario al que está destinada la vivienda y que queda vinculado al Estado, ya que debe abonar las cuotas estipuladas, haciendo la devolución y retorno a dicha entidad. Se observa una ubicación pasiva, desarticulada e individual de las personas a quienes va destinada la política social. El circuito se inicia y termina en el Estado con una distancia y separación de aquella población a la que dirige su acción y constituye su razón de existir.

- Modelo de Autogestión: se prioriza la organización social de los sectores populares que proponen el proyecto, los destinatarios acuerdan con la entidad del Estado, ejecutan y administran la obra, ya sea de manera de autoconstrucción o por contrataciones de pequeñas o medianas empresas, y según los acuerdos, reintegra al Estado lo financiado. A su vez, la organización contrata la empresa y la asistencia técnica, guardando para sí las decisiones que deben responder al acuerdo primero con el Estado. La organización de las familias se constituye en actor dinámico, activo, conduce el proyecto y tiene la dirección del mismo, mostrando un nivel de participación significativo y presupone respuestas más apropiadas a la realidad de los sujetos a los que va destinada la política en cuestión; además de colaborar en su desarrollo, lo que implica alcanzar objetivos que trascienden la necesidad habitacional.

- Modelo de Mesa de Concertación: se movilizan varios actores que se interrelacionan y participan del programa según los acuerdos establecidos entre ellos, donde cada uno discute y actúa en función de sus propia identidad en defensa de sus intereses. Está basado en los mismos principios que el modelo anterior pero tiene que ver con el plano político más allá de un programa 
específico. En la concertación son varios los actores que intervienen (actores locales, regionales, nacionales, organizaciones barriales, federaciones) según los niveles de aplicación de las políticas, y crean la base de acuerdos y compromisos sobre los cuales luego se pueden asentar diferentes tipos de programas, y se establecen los marcos generales que darán origen a las diferentes operatorias.

Si bien los modelos de autogestión y de concertación son importantes por la participación activa, propositiva y responsable de las familias a su vez requieren de políticas sociales de hábitat flexibles que $\operatorname{sean}^{2}$ :

- Contenedoras de variadas propuestas para responder a las múltiples situaciones de la demanda.

- Participativas en relación a la población más desprotegida y en situación de vulnerabilidad.

- Reconocedoras de las capacidades y potencialidades de los sectores populares quienes con asistencia técnica adecuada, son capaces de administrar y ejecutar programas de hábitat.

- Integrales o con enfoque sinérgico, y que vinculen la respuesta habitacional y la generación temporaria de trabajo.

Así, el Derecho a la Vivienda, las Políticas Habitacionales, los Modelos de Acumulación Económica y los Modelos de gestión de dichas políticas (participación) son las dimensiones del problema seleccionadas para analizar las operatorias y las entrevistas.

${ }^{2}$ Servicio Habitacional de la Asociación de Vivienda Económica SEHAS-AVE (2003) 


\section{Capítulo II}

\section{Antecedentes del Instituto de la Vivienda}

\section{Antecedentes Nacionales de la Política Habitacional:}

Recién en 1915, el Estado interviene en la construcción de viviendas obreras con fondos que provenían de las carreras hípicas, que fueron escasos, ya que en veintiocho años sólo se construyeron 977 viviendas. Según López (2002) debido al crecimiento de la población de Buenos Aires - a raíz de la inmigración- se hubiera necesitado construir, aproximadamente, doscientas mil viviendas; pero el Estado liberal en el marco del Modelo de Acumulación Económica Agroexportador iniciado en 1880 (a través de sus instituciones vigentes, el Banco Hipotecario Nacional y la Comisión Nacional de Casas Baratas) dio respuestas tan solo al 1\% de la población necesitada.

En 1921, la acción del Estado está dada por la sanción de leyes de congelamiento de alquileres debido a que la mayoría de la población obrera ocupa viviendas en alquiler.

En lo político, a partir de la crisis de 1930, con el primer golpe militar se inicia - hasta 1946 - la denominada década infame que estuvo marcada por la corrupción y el fraude electoral.

En lo económico, comienza a cambiar el Modelo de Acumulación Económica Agroexportador por el Modelo Sustitutivo de Importaciones.

Desde 1946 hasta 1955 con el gobierno democrático del presidente Perón empieza una época de desarrollo económico con justicia social denominada justicialista, la cual estuvo caracterizada por la construcción de un Estado benefactor en términos sociopolíticos y una lógica keynesiana en lo económico.

En esta etapa aparecen un conjunto de políticas de vivienda para cumplir con objetivos de justicia social en el marco del Primer y Segundo Plan Quinquenal, a través del fuerte estímulo a la construcción que generaba desarrollo en las industrias nacionales de insumos asociadas con la consiguiente generación de empleo.

Dentro del Primer Plan Quinquenal, el objetivo en materia de vivienda era asegurar a todos los habitantes del país la posesión de una vivienda adecuada, higiénica, 
confortable y económica. También el Estado mediante el Banco Hipotecario posibilitaba el acceso al crédito barato provocando una redistribución de ingresos, junto a la sanción de leyes para promover la inversión en la construcción orientada al consumo de los sectores medios, la protección a los compradores de terrenos en cuotas, las expropiaciones de tierras con fines sociales; y la reforma de la Constitución Nacional que incorpora el Derecho a la Vivienda para los trabajadores, entre otros derechos sociales. En este período se realizan importantes conjuntos habitacionales como Ciudad Evita en el partido de La Matanza.

Así, según López (2000), las políticas de la época pueden ser ordenadas en tres grupos de acuerdo al sector social al que están orientadas:

- Sectores medios: el acceso al lote, al crédito y la legislación de protección al inquilino (prórroga de contratos, estabilización del precio e impedimento de desalojos),

- Sector de los trabajadores: la construcción de viviendas por parte de los gremios y las provincias;

- Sectores pobres (impedidos de pagar su vivienda): la construcción de viviendas por medio de la Fundación Eva Perón.

\section{Antecedentes Provinciales de la Política Habitacional: EI Instituto de la Vivienda Obrera}

Tomando a la autora Igarzabal (1999) se puede mencionar como antecedente provincial del IVBA al Instituto de la Vivienda Obrera, creado por el Decreto/Ley 4551 en el año 1937, con destino al estudio y la construcción de viviendas económicas, individuales o colectivas, que fueron financiados con recursos provenientes de un adicional aplicado al impuesto inmobiliario sobre la valuación fiscal de propiedades urbanas y rurales de la provincia.

Su diligenciamiento fue realizado por la Comisión Provincial de La Vivienda Obrera, instituido por el decreto 14 del año 1937, para recopilar antecedentes nacionales y extranjeros, señalar las tierras fiscales, proyectar los barrios obreros (plazas, clubes, jardines de infantes y estaciones de sanidad), el financiamiento, aconsejar al gobierno sobre las medidas convenientes para la construcción de 50.000 casas (para los obreros del campo y de las ciudades); y elaborar el anteproyecto de ley creando, a su vez, la entidad autárquica de la vivienda obrera con las reglamentaciones pertinentes y las personas que compondrán la Comisión en el plazo de tres meses, todas designadas por el ministro de gobierno provincial Roberto Noble (quien fundara el Diario Clarín). 
El gobierno provincial de Manuel A. Fresco transcurrió en una época cuya economía se basaba en el Modelo de Acumulación Económica Sustitutiva de Importaciones, y en un modelo político autoritario y conservador donde el poder ejecutivo nacional estaba a cargo de Agustín P. Justo. El ejecutivo provincial, desde su discurso (visualizado a través del decreto 13,1937$)$ plantea un sistema de intervención social para benefício de la comunidad obrera agraria e industrial cuyas condiciones de existencia y retribución escasas hacían urgente el apoyo de los sectores públicos. Estaban amparados en un discurso que enunciaba los siguientes propósitos:

- justicia social: relacionado a la crisis económica y moral mundial, se pretende evitar mediante soluciones constructivas el desarrollo en nuestro país de tendencias y sentimientos contrarios a la nacionalidad y a las instituciones tradicionales como la patria, la familia y la religión.

- asegurar desde el Estado que participen, equitativamente, en los beneficios de la educación, de la higiene, del bienestar y del esparcimiento, de acuerdo a los recursos de la técnica moderna y en proporción a las aptitudes de cada ciudadano.

En definitiva, el discurso utiliza las legítimas demandas de los trabajadores: como la justicia social y la vivienda, pero la acción que despliega está orientada a evitar el cambio social y la pérdida de los privilegios de la oligarquía que está amenazada por los inmigrantes imbuidos por las ideologías del socialismo revolucionario (como solución de la crisis del capitalismo) y prevenir así la movilización obrera.

En dicho (decreto/ley 13,1937) se afirma que los funcionarios provinciales comprobaron las condiciones precarias y peligrosas para la salud pública de la vivienda obrera, lo que fomenta la promiscuidad, la falta de higiene, el desarraigo y la incomodidad en la habitación, que preparan los gérmenes de inquietud, de descontento y perturbación social que los poderes del Estado deben evitar mediante los arbitrios basados en la justicia y en la dignidad humana.

Por lo tanto se promueve para solucionar el problema a la vivienda decorosa, cómoda e higiénica, que en el:

- orden material: previene contra los peligros de la higiene insuficiente, proporcionando a sus habitantes los elementos técnicos de comodidad y 
bienestar propios de la construcción moderna, y estabiliza la economía del jefe de familia mediante la propiedad de la casa,

- orden moral: evita los males de la promiscuidad, asegurando a los niños un refugio contra las acechanzas y seducciones de la vida callejera (abandono, mendicidad y delincuencia infantil), y fomenta a la población obrera sentimientos de decoro, de propia seguridad y de buenos hábitos.

Desde el discurso imperante en este decreto (13/37) se acude a las ideas de asistencialismo moralizador: donde el Estado intenta fortalecer los vínculos familiares para ayudar a las clases trabajadoras a "moralizar" sus comportamientos y facilitar su educación, por ser la forma más económica de asistencia mutua, pues de esta manera también evita el conflicto social. Apela a la intervención Médico Higienista que explica los males sanitarios en el hacinamiento. López (2000) plantea como el discurso higienista es utilizado como estigma para obtener la excusa de intervención del conventillo habitado por los inmigrantes (debido a que es el sector sospechado de revolucionario), ubicándolos en los barrios obreros y utilizando un sistema de vigilancia en el cual el gobierno se entrometía dentro de las familias.

El decreto 13 continúa diciendo que está demostrado que el alquiler de una vivienda insume el cuarenta por ciento del presupuesto familiar obrero y por lo tanto el Estado debe arbitrar, en las condiciones menos onerosas posibles, la forma de proporcionar la vivienda y su título de propiedad correspondiente para lo cual en el breve plazo se arbitrarían los recursos necesarios para construir cincuenta mil casas individuales en los campos y las ciudades para la población obrera.

Las casas constarían de dos piezas amplias, cocina y baño, con facilidades para adquirirlas en propiedad a través de reducidas cuotas mensuales. Determinándose como los lugares considerados más imperiosos en la provincia de Buenos Aires a: Avellaneda, Mar del Plata, Campana, Tres Arroyos, La Matanza, San Martín, y General Sarmiento, entre otros.

La Ley 4551 del año 1937, sancionada por el Senado y la Cámara de Diputados de la Provincia de Buenos Aires crea al Instituto de la Vivienda Obrera de la provincia de Buenos Aires, que será administrado por un directorio compuesto por un presidente y dos vocales que durarán cuatro años en sus funciones y serán designados por el Poder 
Ejecutivo con acuerdo del Senado (ciudadano, mayor de 30 años de edad, con tres años de domicilio en la provincia e inscripción en su registro electoral). La relación entre el Poder Ejecutivo y el Instituto se da por intermedio del Ministerio de Gobierno.

Dicha ley hace referencia a las funciones del directorio, del presidente, al fondo permanente (constituido por un adicional al impuesto inmobiliario, recursos del Estado y donaciones), y a los beneficiarios, entre otras disposiciones.

Si bien el Instituto de la Vivienda Obrera se crea en una etapa cuya economía está signada por el emergente Modelo Sustitutivo de Importaciones, su modalidad de intervención aún continúa con la lógica liberal positivista propia del período anterior, cuya base económica era la agroexportación. Esta lógica está signada por la estrategia de moralización, la ausencia del derecho y el control social. La ley, siguiendo este paradigma, define a las personas a quienes iban destinadas las viviendas (como beneficiarios), a quienes se les otorga un beneficio sin reconocérseles un derecho. Éstos deberán acreditar buena conducta, un ingreso menor a 200 pesos mensuales, con familia constituida de acuerdo a las leyes, que siendo soltera tenga parientes a cargo y si no los tuviera que hiciese vida normal, siendo prioritarios quienes tienen mayores cargas de familia y luego menor entrada mensual; para lo cual deberían inscribirse en un registro de solicitantes.

Según Torrado (1999) con instituciones que se ocupan principalmente de las mujeres (en el aprendizaje de habilidades domésticas y prevención de enfermedades contagiosas) y los niños, para prevenir lo que pudiese amenazarlos y sancionar lo que pudiese volverlos amenazadores (a través de las madres, las instituciones hospitalarias, la escuela y los asilos), se intenta encuadrar a los miembros de los sectores populares urbanos en las pautas de conducta compatibles con la necesidad de crear individuos aptos para el trabajo subordinado y aceptación del modelo de sociedad argentina del momento, asimismo para contener el avance de ideas socialistas o anarquistas entre los trabajadores.

Posteriormente, éste también será el criterio del Banco Mundial acerca del rol de las mujeres y/o jefas de hogar en sus recetas para aplicar sobre países como la Argentina cuyo paradigma de costo-beneficio implica intervenir sobre el rol de la mujer y/o jefas de hogar para lograr la eficiencia de un proyecto, ya que se interviene a la vez sobre sus hijos) y con una inversión menor se obtiene un beneficio mayor. 
Éste y otros dispositivos de integración social, como la escuela pública, la regulación de la patria potestad, la instalación de registros obligatorios (sanitario, policial, municipal, impositivo y laboral) y el asociativismo, unidos a una prédica ideológica que asocia la obtención de la casa propia con la respetabilidad y el ascenso social, impulsando el esfuerzo y el ahorro de los trabajadores al logro de ese objetivo moralizador, contribuyen a: arraigar, uniformar e integrar a los extranjeros al ideal de familia cristiana enraizados en la clase media.

Torrado (1999) dice que este tipo de medidas les aseguran funciones de beneficencia a los pobres y con poca intervención del Estado, porque la idea de la élite liberal dominante es evitar que el socorro social se constituya en una cuestión de derecho, ya que admitir el derecho a la asistencia (más tarde el derecho al trabajo) supone entre benefactor y beneficiario una relación entre iguales cuando la propiedad privada requiere mecanismos de intercambio desigual: el indigente recibe sin dar contrapartida y su relación con el dador no llega a la esfera del derecho.

Para Carballeda (2006) desde el surgimiento del Estado nación argentino, las prácticas de profesionales o técnicas que actúan en lo social, a través de distintos procedimientos de intervención, están signadas por los parámetros del positivismo con preceptos socio biológicos que se inicia con el paradigma indiciario que surge para la identificación de delincuentes y pacientes psiquiátricos y que se extiende a toda la sociedad; por ello se relaciona con las políticas de individuación y disciplinamiento para enderezar conductas mediante técnicas correctivas orientadas a la vigilancia jerárquica (interior), la sanción normalizadora (señalar lo anormal y castigarlo) y el examen (observación, entrevista y diagnostico).

De este modo, el proyecto de Estado nación se asocia a la calidad económica de sus individuos y a la predominancia de determinados rasgos, donde la medicina - y también su articulación con la justicia (persiguiendo a los inmigrantes por sus ideas) - comenzó a explicar y a actuar sobre la pobreza, siendo el espacio de ejercicio la vida cotidiana como lugar de integración o de fractura de la sociedad a partir de las ideas que la oligarquía dominante tiene acerca de las características socio-culturales de los inmigrantes (sus ideas políticas comunistas y anarquistas) y sus espacios habitacionales (inquilinatos, conventillos) asociados a las epidemias, que estaban ubicados en la periferia de las ciudades y sobre los cuales se intenta prevenir enfermedades, se vigila la 
higiene de la habitación y se analiza si las familias cumplen con los preceptos básicos de higiene.

Por lo tanto, el Estado es organizador de la sociedad en base a las ideas de un partido político de notables en una democracia restringida, donde las nuevas instituciones educativas, jurídicas, sanitarias y militares se consideran como programa de gobierno liberal positivista; confiriendo de una connotación moral a la condición de pobreza, y sirviendo como explicación de la exclusión social a través de características individuales como el medio social y las pautas culturales (la Sociedad de Beneficencia y las Ligas premian a quienes cumplen con los preceptos higiénicos y se amoldan pasivamente). Así, la anomia, el conflicto social y el disciplinamiento atraviesan las instituciones de la época donde el medio social genera problemas sociales no desde la falta de derechos sino ligado a pautas culturales.

Y se puede decir que el origen de las instituciones impregna sus prácticas aún en épocas posteriores, tal como se ve en el Instituto de la Vivienda Obrera que si bien surge en el Modelo Sustitutivo de Importaciones está impregnado por la lógica liberal positivista propia del Modelo Agroexportador anterior.

Retomando, el decreto reglamentario de la Ley 4551/37 determina la adopción de un reglamento que fije orgánicamente las funciones del Instituto de la Vivienda Obrera y las formas de acción de sus dependencias, de los contratos con los beneficiarios, y de las construcciones (casas individuales o colectivas).

Con respecto a las casas individuales debían reunir como mínimo las siguientes características: orientar las habitaciones principales hacia cualquier punto cardinal menos hacia el sur, las superficies mínimas -por persona- para los dormitorios de seis metros cuadrados por personas adultas o menores (y en ningún caso la superficie de cada habitación será inferior a los nueve metros cuadrados), la altura de las habitaciones principales de tres metros y de las secundarias de dos metros y medio, todas ventiladas al exterior y si ventilan a patios, éstos tendrán como mínimo catorce metros cuadrados. Los materiales de construcción serán siempre de primera calidad estableciéndose en los contratos de construcción sus respectivas características, dándose preferencia a los de procedencia nacional, y debiendo tener cada casa su baño y cocina con todos sus artefactos instalados siguiendo la reglamentación de Obras Sanitarias de la Nación. 
Por su parte, las casas colectivas debían reunir como mínimo las mismas características que las casas individuales, y además, permitir la existencia de patios de un mínimo de doce metros entre cuerpos edificados, y cuatro metros de distancia entre el eje de la medianera del terreno a cualquier construcción.

Las casas colectivas no podrián tener más que planta baja y tres pisos altos como máximo, las entradas y sus correspondientes escaleras colectivas no podrán tener servidumbre para más de doce casas o departamentos, y cada casa deberá tener una instalación especial para lavadero, recolección de basuras y desperdicios, así como horno incinerador de los mismos que serán comunes a todos los departamentos.

En cada grupo de casas colectivas (de hasta tres cuerpos) habrá por lo menos un local destinado a juegos de niños o "nursery" con todos los locales propios de este servicio social, y se irán agregando a razón de un local cada tres cuerpos.

Como se menciona al inicio del presente capítulo, dentro del período caracterizado por la economía de sustitución de importaciones -a partir de 1943 y hasta 1955- con la etapa justicialista se abre un proceso político diferenciado donde se cuestiona fuertemente el modelo de intervención liberal positivista y el Estado interviene desde un enfoque caracterizado por el derecho. En esta etapa se profundiza el debate entre los profesionales sobre la conveniencia de las casas individuales o colectivas para hacer efectivos los ideales de justicia social. En este punto cabe hacer referencia a Aboy (2003) quien estudia en profundidad este período, donde coexisten dos modelos sociales y urbanos diferentes en relación con la vivienda, relacionados por un lado con la aspiración de ascenso social cuyo emblema es: "el sueño de la casa propia" y por otro: los idearios de igualación social y conciliación de clase, asociados con diferentes tipologías de viviendas. Así:

- El modelo de barrio vecinal: con la vivienda individual en lote propio es apta para encarar el ascenso social y la respetabilidad burguesa, como los barrios Primero de Marzo y Juan Perón, en Saavedra, o Ciudad Evita, que corresponden a este modelo donde cada casa individual es habitada por una familia, logrando una relativa independencia de sus vecinos.

- El modelo del barrio obrero: con la vivienda colectiva moderna cristaliza la aspiración igualadora, construido en base a pabellones, materializando una ciudad de iguales. Cada bloque es habitado por distintas familias y cada familia se aloja 
en una unidad de vivienda, allí comparten los accesos, circulaciones y espacios exteriores de la planta baja, circunstancias que favorecen el intercambio social (y político) entre vecinos. Dentro de este modelo existen dos tipos de construcciones:

- De pabellones bajos como el barrio Los Perales y El 17 de Octubre construidos en 1948-1949 correspondientes al Primer Plan Quinquenal.

- De pabellones altos como los Barrios Curapaligüe y Marcelo T. de Alvear construidos en 1954 correspondientes al Segundo Plan Quinquenal.

Para Aboy, las formas espaciales adoptadas para la realización de los barrios, según los modelos urbanos y sociales detrás de ellos, asume al espacio material de las viviendas como marco productor de identidades, a la vez que es el producto de las prácticas sociales de quienes lo habitan. El modelo de vivienda individual, responde a las orientaciones impulsadas desde los sectores vinculados al catolicismo, quienes ven en la vivienda individual el hogar de la familia cristianamente constituida, que está fundada en el matrimonio indisoluble. Mientras que el segundo modelo de vivienda colectiva enlaza con aspiraciones comunitarias y de igualación social.

De este modo, la forma material de la arquitectura de las viviendas se asocia con ideas como la nacionalidad, la identidad y la búsqueda de un estilo propio, y manifiesta una preferencia excluyente por el modelo de la casa individual para dar habitación sana, y cómoda a los argentinos, identificando como propio al estilo español y por extranjero a lo moderno.

Ampliando lo expuesto, para Ballent (2005) la producción de viviendas en este período con distintas estéticas de arquitectura pintoresca o arquitectura modernista tienen que ver con la pugna entre diferentes sectores del Estado por imponer distintas formas de representación de dicho Estado y de política. El peronismo busca acercar ésas formas de habitar de los sectores altos y medios al habitar popular masivo a través del chalet californiano (chalecito peronista) que es el símbolo de la adquisición de nuevos derechos y de la extensión del bienestar, con la redistribución de espacios públicos anteriormente ajenos. Sin embargo, este imaginario presenta contradicciones en términos de identidad con las clases altas y pertenencia a las mismas (ya que se construye una idea de ascenso social e identidad de clase que atenta contra el mismo peronismo). En las obras de la Fundación de Eva Perón se evidencia el derecho a la belleza, ya que son obras que ofrecen un valor estético a un público anteriormente 
excluido de su goce; y también se estimula el uso popular del espacio público (que antes no lo tenía).

\section{Algunas conclusiones:}

De la suma originalmente destinada para la construcción de viviendas por el Instituto de la Vivienda Obrera, en los distintos partidos de la provincia, se desconocen datos sobre su realización, puesto que solo se conoce la concretización de viviendas para uso de encargados viales.

La distancia entre el discurso y la práctica se evidencia - según Molteni y Galcerán en Gutiérrez (2011) - en que las cincuenta mil viviendas se redujeron a 2000 y cuando se produce la intervención en la provincia en 1940, dicho Instituto solo tenía en carpeta tres proyectos y un anteproyecto.

De lo expuesto, se demuestra que el Instituto de la Vivienda Obrera no ha tenido influencia de la etapa justicialista.

Más tarde, el sucesor de este Instituto de la Vivienda Obrera fue la Dirección de la Vivienda Económica del Ministerio de Obras Públicas, que luego se transforma en la Dirección de la Vivienda, para luego desaparecer con la creación del actual Instituto de la Vivienda de la Provincia de Buenos Aires (IVBA). 


\section{Capítulo III}

La Política Habitacional del Desarrollismo y el Nacimiento del Instituto de la Vivienda de la Provincia de Buenos Aires

\section{III.1- La Política Habitacional del Modelo Sustitutivo de Importaciones en su etapa Desarrollista (1955-1976)}

\section{Contextualización del período:}

La Política Habitacional en este período es coincidente con el Modelo de Acumulación Económica Sustitutivo de Importaciones en su etapa Desarrollista (el modelo ya había comenzado en 1930, con una etapa Justicialista tomando desde 1946 hasta 1955). Y en lo político se caracteriza por constantes interrupciones a la vida constitucional y democrática del país por gobiernos de factos (desde 1955 a 1958; 1962 a 1963 y de 1966 a 1973), hasta que de 1973 a 1976 vuelve al poder el peronismo.

Este período es descripto por Torrado (1999) en el contexto de la proscripción del peronismo de la política nacional, donde accede al poder un bloque aliado entre la burguesía industrial nacional y el capital extranjero (corporizado por empresas transnacionales norteamericanas), por medio de una nueva estrategia concentradora centrada en una industrialización sustitutiva de bienes intermedios y durables para consumo del reducido estrato social de altos ingresos, con el incremento de la demanda dado por la inversión, el gasto público y el consumo suntuario del estrato social urbano con altas entradas económicas. Este modelo implica un proceso regresivo de concentración de la renta donde el Estado ayuda a la capitalización y concentración económica que se despliega mediante sus funciones como productor de bienes y servicios, y como agente distribuidor de los recursos sociales. Se reduce el gasto e inversión social y se registra un deterioro generalizado de niveles de bienestar social. En términos de salud, disminuye la esperanza de vida, en vivienda se deteriora la situación habitacional y en educación se retrasa a nivel primario y se lentifican los ritmos del nivel secundario y superior.

El límite a este modelo está dado por la crisis recurrente de la balanza de pagos, agravada por la remisión de utilidades y pagos por tecnología al capital extranjero, y la agudización del conflicto social con las protestas por parte de los sectores populares, 
que termina con una crisis institucional que se resuelve con el llamado a elecciones en 1973 y la asunción del tercer gobierno justicialista.

\section{Descripción de la Política Habitacional del Período (1955-1976):}

El Crecimiento de la Región Metropolitana de Buenos Aires; se inicia en 1930 hasta 1970 y, según Calello (2000), está dado por la espacialización del Modelo Sustitutivo de Importaciones, ya que teniendo como eje central al puerto de Buenos Aires y a la urbe circundante, dicha región trasciende sus límites originales y adquiere un desarrollo específico y autónomo; promovido por el desarrollo de bienes de consumo duradero y bienes de capital simple como textiles, alimenticios, químicos y mecánicos que asientan un gran número de pequeñas y medianas empresas (pyme) en la Capital Federal y los partidos colindantes que concentran la ubicación de la clase obrera. El desarrollo y consolidación del primer cordón industrial que constituye el conurbano bonaerense (incluye las municipalidades de Avellaneda, Lanús, Lomas de Zamora, norte de La Matanza, Morón, Tres de Febrero, General San Martín, Vicente López, San Isidro y San Fernando) atrae una población migrante del interior del país que es la base de los movimientos sociales y políticos de la época. Esta configuración urbana predomina hasta la década del 70.

$1^{\text {a }}$ Fase del Modelo Sustitutivo (Justicialista): la nacionalización de los ferrocarriles, transportes, teléfonos, gas, electricidad, banco central, puertos, empresas de seguros, servicios públicos y recursos naturales consolida en la década del 40 un régimen de acumulación de capital (que se había iniciado en 1930) que se basa en la expansión de la burguesía industrial nacional y del consumo interno que cimienta la alianza entre el capital y el trabajo, los sindicatos y las reivindicaciones sociales que favorecen las condiciones laborales de los asalariados. Con la creación del Instituto Argentino de Promoción Industrial se transfieren las rentas agrícolas al sector industrial.

En los primeros años de la década del 50 comienza el agotamiento de este modelo por los cuellos de botella producidos en la balanza comercial debido a la restricción de la exportación argentina a los mercados europeos y la necesidad de importar los insumos no producidos en el país. 
$2^{\text {a }}$ Fase del Modelo Sustitutivo (Desarrollista): además de la crisis de las políticas distributivas de ingresos al afectar las tasas de ganancias, las industrias de bienes para el consumo masivo se estancan y se reconsidera la política de inversiones extranjeras directas atendiendo a las industrias pesadas y semi-pesadas que se instalan durante la presidencia de Frondizi (1958-1962), iniciándose de esta manera la a segunda fase del proceso sustitutivo de importaciones, conducida por los sectores: metal mecánico y petroquímico. A su vez, mediante la devaluación de la moneda nacional se favorece a las empresas exportadoras y fortalece los aspectos autoritarios del Estado en relación a los partidos políticos y los sindicatos.

Según Torres (1993) la expansión urbana entre 1940 y 1960 adopta dos formas. En la periferia se produce un tipo de suburbanización protagonizada por los sectores de menores ingresos, los loteos económicos y la autoconstrucción; y en la zona urbana consolidada central y subcentral (Capital Federal) se desarrolla una densificación urbana protagonizada por los sectores medios (departamentos en propiedad horizontal).

Según Lombardo (1999), las ideas que guían el desarrollo urbano de 1946 a 1955 se basan en la propiedad privada inmobiliaria y la forma privada de producir la ciudad, bajo el control, la coordinación, la financiación y el apoyo del Estado. Es una concepción racionalista, fundamentada en la consideración funcional del espacio y la ciudad, y la necesidad de su planificación, la vivienda individual en propiedad para el grupo familiar, agrupada en forma vertical y horizontal, como la base del orden espacial, son las ideas que se formulan en los planes quinquenales.

Para Calello (2000), el proceso histórico de urbanización da como resultado una estructura urbana orientada, geográficamente, a lo largo de los ejes principales de transporte: por las vías férreas, las vías de transporte automotor y la vinculación vial intersticial, entre los ejes que tienen una dirección desde el centro de Buenos Aires hacia la periferia. Esta configuración tentacular presenta áreas con diversa densidad de población, de infraestructura urbana y dotación de servicios, decreciendo desde los ejes centrales hacia los grandes espacios entre estos ejes. Dicho proceso se funda en el apoyo que brinda el Estado al desarrollo del transporte y la vivienda, subsidiando las tarifas de transporte lo que facilita el desplazamiento masivo de trabajadores en un proceso de urbanización creciente que complementa las facilidades para lotes en zonas cada vez más alejadas de la ciudad capital y con escasas dotaciones de servicios e infraestructura, 
a través de los loteos económicos. Desde 1955 se acentúa el predominio del mercado y su influencia en la urbanización de la región facilita el desarrollo del Segundo Anillo o corona en el Gran Buenos Aires, (incluye las municipalidades de Tigre, General Sarmiento, Moreno, Merlo, centro y sur de La Matanza, Esteban Echeverría, Almirante Brown, Florencio Varela, Berazategui y Quilmes).

Según Torres (1993), desde 1960 se producen modificaciones importantes en los usos legales del suelo $\mathrm{y}$ en el proceso de suburbanización, que terminan con las permisividades de las reglamentaciones anteriores; también se disminuye el subsidio al transporte, finaliza el proceso de loteos económicos, cae la tasa de crecimiento del Gran Buenos Aires, aumenta el deterioro de las condiciones socio-habitacionales y se incrementa la cantidad de habitantes en las villas miseria.

Profundizando con Pírez (1994) el Modelo de Industrialización Sustitutiva de Importaciones en la etapa Justicialista, que conforma la región metropolitana, consolida el papel de la pampa húmeda y la ciudad de Buenos Aires en el desarrollo nacional como centro administrativo y político-nacional. Con la población y mercado urbano más importante, la fuerza de trabajo, el puerto por donde se importan las maquinarias e insumos para la industria concentra las comunicaciones ferroviarias y las principales actividades comerciales y financieras, como así también una base industrial formada por pequeños talleres. Hacia fines del año 40 se inaugura el Aeroparque Jorge Newery, el Aeropuerto Internacional de Ezeiza y la autopista que lo conecta al centro. Las nuevas industrias productoras de bienes de consumo no durables atraen población del interior del país la cual provoca una fuerte corriente migratoria. Esta metropolización se da en un contexto de desarrollo económico con pleno empleo y distribución del ingreso hasta mediados de los años 50.

La expansión del área metropolitana a partir del asentamiento de la población de menores recursos se produce por medio de dos tipos de localizaciones: los loteos populares y las villas miseria, aunque su significación social es diferente. La suburbanización metropolitana consolida la diferenciación entre el Norte ocupado por los sectores sociales de mayores ingresos, el Sur y Sur-Oeste con los sectores de menores recursos, y como contrapartida, el centro de la ciudad se consolida como lugar de los sectores altos y medios. 
El comienzo de la etapa desarrollista (en 1955) consolida un modelo orientado a la incorporación del capital externo, la producción de bienes de consumo duradero y la desnacionalización de la industria. Estos cambios modifican el patrón de configuración territorial ampliando el área de localización, en el que incide la decadencia del ferrocarril y el nuevo peso de la comunicación vial y las autopistas (en especial el acceso norte que conecta Capital con las nuevas áreas industriales), ampliándose así el radio territorial de concentración. Las grandes empresas si bien mantienen las oficinas en la Capital Federal colocan sus plantas fuera de los marcos físicos urbanos pero en su cercanía. Los cambios territoriales se reflejan en la detención del crecimiento metropolitano, la capital expulsa población y los municipios bonaerenses del área metropolitana la reciben. Se configuran de esta manera dos realidades diferentes denominadas: primera corona y segunda corona, en esta última se encuentra la mayor cantidad de población.

El Modelo Sustitutivo de Importaciones, primeramente en su etapa Justicialista (19451955) había tenido una lógica basada en principios keynesianos, un Estado intervencionista y una política centralizada- a través de regulaciones- el reconocimiento con rango constitucional del Derecho a la Vivienda, las leyes de propiedad horizontal, el congelamiento de alquileres, la venta de terrenos en cuotas y la obra pública (con una gran construcción de viviendas de forma directa por el Estado o indirecta por el Banco Hipotecario), las viviendas sociales en busca de justicia social y redistribución de ingresos; todo permite un gran avance en la efectivización del Derecho a la Vivienda.

La Etapa Desarrollista, que comienza a partir de 1955 y se va a prolongar hasta 1976, con el golpe de Estado, reinstaura el predominio de los sectores conservadores y aumenta la presencia del capital transnacional en la economía nacional; se liberaliza el mercado de alquileres (provocando un fuerte aumento de las mensualidades), se reduce el crédito hipotecario blando; y se despliegan políticas sociales que intentan contener el conflicto no garantizar derechos.

Borthagaray (2007) distingue en este período la creación de la Comisión Nacional de la Vivienda (1955), la creación del Instituto de la Vivienda de la Provincia de Buenos Aires (1956), la organización del Fondo Federal de la Vivienda (1959), la creación de la Secretaria de Estado de Vivienda (1965), y la creación del Fondo Nacional de Vivienda FONAVI (1970) que da operatividad a la Política Habitacional con la construcción de 
conjuntos habitacionales llave en mano, que reúnen vivienda, equipamiento e infraestructura.

Según Aparicio (2010), después de los años 50, a pesar de las medidas tomadas por el gobierno sigue creciendo y agravándose el problema habitacional, y la etapa de construcción de grandes complejos habitacionales (la mayoría de ellos dentro de políticas desarrolladas por gobiernos de dictadura militar) apuntan más a deshacerse de los asentamientos informales a cualquier precio que a ofrecer soluciones reales a un problema que parece no tener fin. Se construyen así, generalmente en las afueras de las ciudades, complejos de viviendas masivos y en altura. Lo mismo que sucede con estos complejos habitacionales en los países que los generaron como en Alemania, ocurre en la Argentina que, además de estar diseñados urbanísticamente para romper con la trama de la ciudad en donde se insertan, se convierten en verdaderas fortalezas de las cuales el primer objetivo como habitante es el de escapar de allí lo antes posible. El Barrio Ejército de los Andes conocido popularmente con el nombre de Fuerte Apache, da cuenta de esta situación. Estos complejos se caracterizan por el mantenimiento inexistente, el deterioro constructivo progresivo, y las ideas de guetización y estigmatización social, con la consiguiente pérdida de valor de las unidades habitacionales.

Es interesante destacar la reflexión de López (2000), acerca de las operatorias de construcción de vivienda en los complejos habitacionales de esta etapa autoritaria orientadas a la intervención de los técnicos en las villas de emergencia- dado que era un espacio de integración social entre sectores marginados (migrantes del interior y de países limítrofes) con pensamiento y acción política (mayormente peronistas que no se resignaban a perder sus derechos) para poder desarticular la organización social y transformar así a la vivienda en la estrategia para entrar en los hogares de los sectores populares.

Si bien no corresponden al IVBA sino a la Comisión Nacional de Vivienda (1955) integrada por técnicos destacados de entes estatales y profesionales pero cabe mencionarse para visualizar que en nombre de la técnica se critica no solo la vivienda sino al destinatario de las mismas, llegándose a proponer la vivienda en adaptación como herramienta educativa (Gutierrez,2011), realizándose en el barrio Rivadavia de la 
Capital Federal, viviendas con camas, mesas y asientos de cemento para que aprendan a vivir.

Para Yujnovsky (1984) desde el año 1955 en adelante, la crisis económica y la exigencia de encontrar una forma de inserción en una economía mundial cambiante, profundiza la concentración y centralización de capital de grupos económicos mayoritariamente transnacionales, la política concreta es no afectar las reglas del mercado especulativo y se da sin un modelo político hegemónico, inmerso en una inestabilidad política entre gobiernos militares de facto y electos que no pueden concluir sus mandatos, demostrándose que la lucha por el derecho a la vivienda es parte de una lucha más grande a favor de la democracia en la sociedad.

En la etapa Desarrollista, con la apertura económica, la decadencia del ferrocarril y el mayor peso de las autopistas, se detiene el crecimiento metropolitano, se amplía el área de localización; la población es expulsada de la Capital hacia la conurbación del área metropolitana, donde se configuran dos realidades diferentes. Por un lado gran concentración de población y por otra, la construcción de vivienda social de alta densidad en las afueras de la ciudad, marcando un fuerte retroceso en la efectivización del Derecho a la Vivienda.

Para Fernández Wagner (2008) hasta los años 70 los valores como el trabajo y la educación son importantes para el progreso social, pero a partir de allí las políticas centradas en los intereses de los grupos dominantes, como el sector financiero internacional, generan una sociedad empobrecida e inequitativa donde el derecho a la ciudad se "compra", coexistiendo una ciudad compuesta por ciudadanos poseedores de derechos y dentro del mercado con otra compuesta por estigmatizados desplazados del mercado, que el Estado contiene para evitar la protesta y el estallido social. Este autor habla del conflicto en el territorio por el derecho a la ciudad, a la vivienda, a la tierra que se ocupa para habitar, la centralidad, la cercanía al lugar de trabajo, y el transporte seguro, que son reclamados por los pobladores y organizaciones; reinstalándose el rol de la política en la configuración de una sociedad más justa, a través de la revalorización de la planificación en instrumentos jurídicos de la política urbana. 
A esta etapa según Fernández Wagner (2007) corresponden las Políticas

Habitacionales de Segunda Generación, que se desarrollan hacia fines de los años 70 y son políticas que básicamente consisten en urbanizar los asentamientos informales, si bien no tienen un sentido explícito en términos de derechos, constituyen un avance ya que, aunque limitadamente, reconocen el "derecho" contraído por la historia del grupo social en el lugar; y si bien forman parte de las recomendaciones de las agencias internacionales tienen un alcance moderado, y no reemplazan las de primera generación sino que conviven con ellas (las políticas de primera generación se dan en un marco de reconocimiento de derechos, fuertemente asociados al trabajo, débilmente sobre derechos al suelo urbano y el ambiente construido, y se desarrollan en gobiernos autoritarios ya sea democráticos o militares, basadas en la planificación centralizada y mecanismos de control social se asientan en un complejo entramado de intereses).

Al analizar la Política Habitacional de la etapa Desarrollista desde la óptica de los arreglos cualitativos Estado- Mercado y Familias se ve que la política se recentra en el Estado pero con una relación de refuerzo de la empresa privada como productora de la vivienda en perjuicio del protagonismo de las familias como actor con derechos. Estos arreglos generan respuestas con una merma en la calidad de las soluciones habitacionales, una disminución en la porción de la inversión social destinada a las clases de trabajadoras y una elevación de los costos de producción generados por las empresas contratistas.

\section{III.2.-Creación y Gestión del Instituto de la Vivienda}

El IVBA se crea el 20 de enero de 1956, mediante el Decreto Ley $\mathrm{N}^{\circ} 469$ del Gobierno de la intervención de la provincia de Bs. As. presidido por el Gobernador Emilio Bonnecarrere, reconociendo como antecedente al Instituto de la Vivienda Obrera. Desde la Ley General de la Vivienda N5396 de 1948 existían otras reparticiones en el Ministerio de Obras Públicas, pero ahora se crea un ente "autárquico" (aunque depende directamente del Ministro de Obras Públicas) para asesoramiento, coordinación y fomento de la iniciativa privada en lo que respecta a la adquisición y/o construcción de viviendas.

En dicho Decreto Ley se considera que la vivienda social debe ser objeto de un tratamiento técnico especializado por un organismo de estructura ágil, racional, y que permita la reactivación de la iniciativa privada, especialmente del sistema de 
cooperativas, para reducir los costos de construcción y el acceso a la vivienda propia para todos los sectores sociales. Este decreto-ley más tarde será derogado por el Decreto Ley 9573 de 1980, sancionado por el gobernador Ibérico Manuel Saint Jeames, que para agilizar la ejecución de los planes habitacionales bonaerenses, elimina la dependencia del IVBA del Ministerio de Obras Públicas apelando a su creación como entidad autárquica de derecho público con capacidad para actuar en forma pública o privadamente dentro del ámbito de competencia (antes desvirtuada por depender del Ministro de Obras Públicas) y reemplaza al organismo Colegiado de Administración (presidente $\mathrm{y}$ tres directores: técnico, económico-financiero y jurídico) por un Administrador secundado por un sub administrador. También crea el Fondo Provincial de la Vivienda (FO.PRO.VI) para ser administrado por el Instituto (compuesto por recursos como las disponibilidades en efectivo y cuentas bancarias del Instituto, con lo producido por la venta o alquiler de bienes muebles, donaciones, la participación que corresponda del FONAVI y aportes específicos), y la canalización de los recursos mediante la aplicación de la Decreto Ley 21581/77 del FO.NA.VI. con destino de aplicación en el ámbito de la Provincia de Buenos Aires.

El Instituto de la Vivienda ${ }^{3}$ primeramente estaba ubicado en la calle 58 entre 6 y 7 , en una casa grande con una entrada importante, hall y varias dependencias. Sus autoridades eran el presidente y tres directores. Luego se creó la Oficina Técnica donde se realizaban los proyectos de las viviendas, la Oficina de Pedidos y Especificaciones Técnicas (OPyET) encargada de realizar los pedidos de materiales y herramientas mediante los llamados a concursos de precios y licitaciones, que luego eran utilizados por los integrantes del Consorcio que iban a ser los hacedores y propietarios de las viviendas. A partir de 1961 a través del sistema de ATEPAM (Asistencia Técnica Esfuerzo Propio y Ayuda Mutua), las personas construían sus viviendas sin saber cuál sería la propia en turnos rotativos de trabajo según sus posibilidades laborales particulares.

Años después se trasladó al IVBA a dos casas antiguas (de techos altos, puertas con vidrios y grandes ventanales) una ubicada en la calle 9 entre 41 y 42 donde funcionaba el Departamento Social y el Departamento de Tierras.

Y la otra casa ubicada en la calle 45 entre 12 y 13, en cuya entrada había un vestíbulo, un gran hall donde estaba la oficina de Mesa de Entradas, con un mostrador de madera

\footnotetext{
${ }^{3}$ Información suministrada por Leticia Arioni compañera jubilada, ex Jefa del Depto. Presupuesto del IVBA.
} 
grande, y a su alrededor las habitaciones convertidas en despachos para el Presidente y sus Directores (Económico Financiero, Técnico y Administrativo); luego un pasillo en los que a cada lado tenía las oficinas de Despacho, Personal, se seguía para llegar a un gran local en el que conjuntamente trabajaba el personal de contable y tesorería.

En Contable se realizaba el registro de todas las operaciones presupuestarias, en unos libros inmensos para erogaciones corrientes y de capital, se confeccionaban los estados contables que requería la Contaduría General de la Provincia, y se efectuaban las órdenes de pago.

En Tesorería se pagaba a los proveedores y contratistas mediante cheques y los sueldos y viáticos en efectivo, también se efectuaban las rendiciones de cuentas, y se efectuaban las órdenes de compra para mantenimiento del organismo).

Luego se ingresaba a otro ambiente en el que estaba la Oficina Técnica, se unificaron las tareas de proyecto, confección de planos, junto a cómputos y presupuestos, para la realización posterior de los llamados de compras (licitaciones y concursos de precios). Dicha casa antigua contaba con un patio, una cocina (en la que servían una colación al personal de té o mate cocido con pan), y oficinas para la Delegación de Contaduría General de la Provincia de Bs. As. y la Biblioteca.

Más tarde (a mediados de los `60 hasta los años 90) el IVBA se traslada a la calle 116 entre 70 y 71 a una dependencia prestada por el Ministerio de Salud hasta que se muda a su actual ubicación en la calle 7 entre 58 y 59, ocupando parte del edificio del Ministerio de Infraestructura, Vivienda y Servicios Públicos de la Provincia de Buenos Aires (desde planta baja hasta el $4^{\circ}$ piso). La estructura orgánica actual del IVBA autorizada por el Poder Ejecutivo Provincial en 2003 se puede ver en el Anexo 1.

Al IVBA se le asigna el cometido funcional básico de asesoramiento, coordinación y fomento de la iniciativa privada para la adquisición y/o construcción de viviendas incentivando la formación de cooperativas y consorcios para la construcción de viviendas y la coparticipación de los municipios en la acción oficial.

En este período se ofrece un financiamiento de viviendas multifamiliares a través de empresas y unifamiliares por autoconstrucción. La estrategia es la de autoconstrucción “asistida". La participación se expresa en la autoconstrucción, la ayuda mutua y el esfuerzo propio. Así se busca reducir los costos en la construcción de las viviendas transfiriendo parte de los mismos a las familias trabajadoras. 
Cabe una aclaración, de aquí en más en la descripción de las operatorias se utiliza textualmente la redacción de Elina Igarzabal (1999) en la que se ve representada la nomenclatura del IVBA de la época, así cabe reflexionar sobre el lenguaje para interpretar lo social, como se verá más adelante, ya desde la denominación de usuario se corresponde a una visión de sujeto que representa cierto lugar que ocupa en la sociedad, las denominaciones de usuario, beneficiario, destinatario tienen que ver con un lenguaje técnico que no reconoce humanidad y derechos a diferencia de sujeto, persona, habitante, ciudadano o vecino.

Como veremos más adelante, ese usuario estaba totalmente afuera de las planificaciones, se trataba de que asuma su rol (de acuerdo al modelo tecnocrático normativo imperante), en su defecto no se analizaba porque no había interés en la persona, lo cual continúa igual, ya que no hay derecho a elegir como vivir, otros toman las decisiones, en la idea de usuario/beneficiario está solo el derecho al uso sin participación, es una idea de sujeto con derechos recortados y no completos.

\section{Operatorias de Vivienda del IVBA en el período de 1956 a 1976:}

Operatoria Acción Cooperativa: 450 viviendas.

Operatoria ATEPAM: 2670 viviendas.

Operatoria Provincia y Municipios (PYM): 4212 viviendas.

Operatoria Entidades Intermedias, compuesta por:

a) Entidades Intermedias Decreto 3201/70: 300 viviendas.

b) Entidades ATEPAM por coparticipación: 243 viviendas.

c) Entidades Plan Fed. De Viviendas Banco Hipotecario Nacional: 495 viviendas.

Operatoria Plan Erradicación de Viviendas Precarias y Rancheríos: 501 viviendas.

Plan Erradicación de Viviendas Precarias y Rancheríos (PEVEP): 6 Conjuntos Habitacionales de 501 viviendas.

Una mención especial merece la Operatoria Barrios Obreros (con vigencia de 1948 a 1971). Caracterizada por:

Objetivo: construir viviendas de interés social ubicadas en terrenos provinciales que en una primera etapa es ejecutada bajo el Régimen de la Ley 5396/48 por el Ministerio de Obras y Servicios Públicos (MOSP), y luego por la Dirección de Arquitectura; 
primeramente quien realizaba la regularización y escrituración de los barrios obreros era el Ente Regulador de la Vivienda y luego es el IVBA quien le sucede en esta tarea.

Financiamiento: realizado por el MOSP a través de Rentas Generales de la Provincia.

Usuario: seleccionado de la demanda general.

Proyecto: conjuntos habitacionales en planta baja realizados por la Dirección de Arquitectura del MOSP.

Tecnología: sistema constructivo tradicional con materiales convencionales.

Ejecución: por intermedio de la Dirección de Arquitectura del MOSP mediante licitación pública y contrato de obra.

Resultado: 151 conjuntos habitacionales de 9244 viviendas (5292 viviendas en el Conurbano y 3952 viviendas en el interior provincial).

Superficie promedio de cada vivienda: $55 \mathrm{~m}^{2}$

Al igual que la Operatoria Barrios Arquitectura: con vigencia de 1948 a 1971. Caracterizada por:

Objetivo: construir viviendas de interés social ubicadas en terrenos provinciales que en una primera etapa es ejecutada bajo el Régimen de la Ley 5396/48 por el Ministerio de Obras y Servicios Públicos (MOSP), y luego por la Dirección de Arquitectura. A efectos de la regularización y escrituración de los barrios obreros se creó el Ente Regulador de la Vivienda en 1969, para sucederle en esta tarea el IVBA,

Financiamiento: realizado por el MOSP a través de Rentas Generales de la Provincia.

Usuario: seleccionado de la demanda general.

Proyecto: conjuntos habitacionales en planta baja realizados por la Dirección de Arquitectura del MOSP.

Tecnología: sistema constructivo tradicional con materiales convencionales y sistemas industrializados.

Ejecución: por intermedio de la Dirección de Arquitectura del MOSP mediante licitación pública y contrato de obra.

Resultado: 93 conjuntos habitacionales de 3068 viviendas (1484 viviendas en el

Conurbano y 1584 viviendas en el interior provincial).

Superficie promedio de cada vivienda: $71 \mathrm{~m}^{2}$ 
Aquí el IVBA, según el estudio de Igarzabal (1999) inicia su actividad productiva concretando la construcción de ocho viviendas industrializadas en La Plata, al mismo tiempo que estructura un régimen operatorio de préstamos para Cooperativas, promoviendo el dictado de leyes y decretos que norman su funcionamiento; y brinda asesoramiento integral constituyendo más de setenta grupos formados por familias de bajos recursos para acceder a la vivienda propia. Así lo hace a través de la Operatoria Acción Cooperativa, cuyo marco legal es el Decreto Ley $\mathrm{N}^{\circ} 14271 / 57$, con vigencia desde 1957 a 1968, y se caracteriza por:

Objetivos: acudir con la construcción o adquisición de viviendas para asociados a las Cooperativas de Viviendas,

Financiamiento: del IVBA interviene para la obtención de créditos del Banco Provincia de Bs. As.

Usuario: seleccionado entre los asociados de la Cooperativa de Vivienda,

Proyecto: presentado por la Cooperativa y aprobado por el IVBA (terrenos y documentación técnica relativa al proyecto, planilla de datos de los adjudicatarios y documentación legal de la Cooperativa).

Tecnología: sistema constructivo tradicional con materiales convencionales.

Ejecución: por intermedio de empresas constructoras contratadas por la Cooperativa de Vivienda e inspeccionada por el IVBA.

Resultado: 8 conjuntos habitacionales de 450 viviendas (ubicadas 305 en el Conurbano y 145 en el interior provincial).

Superficie promedio de cada vivienda $70 \mathrm{~m}^{2}$

Igarzabal (1999) destaca que al mismo tiempo, el IVBA desarrolla otro enfoque operativo promoviendo la construcción de viviendas destinadas a los sectores de población con escasa capacidad de ahorro para acceder a la casa propia, se proyecta el Estatuto Básico de Creación de Consorcios (Decreto 11223/58) que luego deriva en la Ley 6707/61 del Sistema de Asistencia Técnica, Esfuerzo Propio y Ayuda Mutua (ATEPAM), desarrollado entre los años 1961-1976 donde el IVBA aporta terrenos, prototipos de viviendas, equipos de trabajo, asistencia técnica, social y financiera para la adquisición de los materiales, con la participación de la mano de obra de los usuarios. Caracterizada por:

Objetivos: construcción de viviendas a través de la formalización de consorcios para la ejecución por el Sistema de Esfuerzo Propia Ayuda Mutua. El IVBA realiza los estudios integrales de la obra; factibilidad de la localización, estudios previos, proyecto de 
conjunto, viviendas e infraestructura, plan de trabajos e inversiones, ejecutando la obra por administración a su cargo. El área social define la selección de los adjudicatarios realizando tareas de difusión, encuestas domiciliarias y cursos de adiestramiento previo a la ejecución de las obras. Los usuarios aportan la mano de obra regida por la reglamentación de trabajo y contratos.

Financiamiento: realizado una parte por rentas generales de la Provincia y la otra parte por créditos otorgados al IVBA, por la Agencia de Desarrollo Internacional (AID) mediante contrato realizado por decreto 1916/63 entre la Provincia, el Banco Central y EE.UU. En el marco del Plan Alianza para el Progreso, que se verá más adelante según la caracterización de Carballeda (2006).

Usuario: selección y formación de consorcios de trabajo con capacidad autoconstructora tomados de la demanda general por el IVBA.

Proyecto: conjuntos habitacionales en planta baja, dúplex, y tres pisos con infraestructura de servicios realizados por el IVBA.

Tecnología: sistema constructivo tradicional con materiales convencionales y sistemas industrializados pilotos.

Ejecución: obras realizadas por la administración del IVBA con mano de obra aportada por el usuario.

Resultado: 42 conjuntos habitacionales de 2670 viviendas (1412 viviendas en el Conurbano y 1258 en el interior provincial)

Superficie promedio de cada vivienda: $70 \mathrm{~m}^{2}$

Dicha Ley 6707/61 con las modificaciones introducidas por la Ley 9099 que autoriza al IVBA a formalizar contratos por sistemas de ATEPAM incluye en su articulado los derechos y las obligaciones de los "beneficiarios" que aportarán su esfuerzo personal y solidario, contribuyendo el Estado (o instituciones oficiales y privadas) con la asistencia social, las tierras, los materiales, herramientas y equipos de trabajo y la asistencia técnica de las obras a ejecutar y los fondos necesarios para sufragar tales gastos (provenientes de una partida tomada de Rentas Generales y depositada en una cuenta específica en el Banco de la Provincia de Bs. As.).

También en su articulado hace referencia a la adjudicación y transferencias de las viviendas y el pago de las cuotas que deberán satisfacer los "beneficiarios" de las mismas, las cuales una vez canceladas permitirán el levantamiento de la hipoteca gravada en favor de la Provincia y la transferencia del dominio de forma definitiva. 
Aquí cabe hacer una mención al Modelo de intervención social Tecnocrático Normativo que según López (2010) se desarrolló en un contexto mundial signado por la guerra fría entre los países capitalistas y los países socialistas. Así las intervenciones se desarrollaron en una época de influencia de políticas desarrollistas y la perspectiva social funcionalista, basada en un sistema social, compuesto por subsistemas, con estructura normativa y roles de los actores en la sociedad, tal que si se fallara en alguno surge la disfuncionalidad y cuya universalidad no tiene en cuenta la diversidad cultural o social. Este sistema necesita de un Estado de Bienestar para poder funcionar y que posibilite la integración; y toma a Tenti Fanfani (1989) que habla de los servicios técnicos que estimularían el esfuerzo propio y la ayuda mutua aumentando la eficacia bajo la idea de cargar sobre los sectores desfavorecidos la responsabilidad sobre su estado.

Este modelo tecnocrático normativo adquiere relevancia en el IVBA por ejemplo mediante las operatorias de la Política Habitacional, que como dice Rodulfo (2006) se realizan mediante una planificación tecnocrática centralizada con la aplicación de la racionalidad científica en las formas de producción y administración, con una división entre concepción y ejecución, departamentalización funcional, toma de decisiones por expertos, la creación de tecno burocracias de alta especialización, con parámetros de costo eficiencia. Lo cual fundamenta la orientación de las acciones habitacionales hacia soluciones prototipo con la producción masiva y las economías de escala a través del sistema FONAVI (ideado en 1970 todavía dentro del Estado Benefactor), de fondos específicos que dan operatividad a la política de vivienda con un abordaje cuantitativo del déficit con la producción de vivienda nueva organizada en conjuntos habitacionales.

Para Carballeda (2006) las políticas sociales de la década del sesenta se caracterizan por una nueva estrategia de intervención desde el desarrollo de la comunidad que trata de lograr condiciones previas a un progreso y modernización en los países subdesarrollados de América Latina promovida por el Estado. Así el escenario es la comunidad para alcanzar un patrón normal de evolución coincidente con el seguido por los países desarrollados (dada la estrategia política de EEUU de Alianza para el Progreso, para evitar que la revolución cubana sea copiada en otros países y se perjudique su capitalismo); y su marco conceptual reconoce a la sociedad como un todo integrado, funcionando como un sistema social, que ante la necesidad de personas, grupos o comunidades vista como carencia requiere de la intervención de las políticas 
sociales no como resultado de la aplicación de un derecho sino como la cobertura de una falta que deber ser cubierta por un técnico-especialista, con lo cual también se evitan situaciones de conflicto. Por lo tanto la sociedad moderna desarrollada se apoya en una autonomía del individuo funcional al orden social instituido.

Se evidencia como el Plan de Alianza por el Progreso (desarrollismo) interviene socialmente a través del IVBA, el cual proponía una modalidad de vida urbana, con personas con más consumo, más industrias (más capitalismo y menos comunismo). En el Sistema de Esfuerzo propio y ayuda mutua (EPAM Y ATEPAM), el IVBA, aporta prototipos de viviendas, equipos de trabajo, asistencia técnica, social y financiera para la adquisición de materiales con la participación de mano de obra de las personas destinatarias.

Pelli (1994) critica la autoconstrucción de la época que asume una forma "dirigida" cuando la solución habitacional debe producirse a través de un proceso de gestión teniendo en cuenta la sensibilidad de la población al cambio y a las formas, generando vías de participación de dicha población en la gestación y conducción de los procesos de resolución de sus propias necesidades habitacionales para que el desarrollo de los procesos sea tanto un acto de producción como un acto social. A través de un modelo participativo que convierte al habitante específico de cada caso en el principal factor de decisión en la política, en vez de sectores empresariales involucrados en la estructura capitalista, que se consideran necesarios pero secundarios y dependientes, defendiendo así la Autoconstrucción Asistida que es el aporte institucional y el refuerzo al trabajo de construcción espontáneo y autónomo.

En el año 1967 se inicia la Operatoria Provincia y Municipio -PYM- (Decreto Ley 5114/67) mediante la suscripción de convenios con las Comunas, cuyo resultado en 1975, en la primera etapa, es la construcción 169 conjuntos habitacionales de 3812 viviendas (ubicadas 143 en el Conurbano y 3669 en el interior provincial).

La segunda etapa de este régimen operatorio se implementa a través de la ley 9104/78 vigente hasta 1983, norma legal de descentralización provincial y particularmente con el decreto 1561/78 que asigna al IVBA el carácter de organismo natural para la aplicación de política habitacional vigente hasta la actualidad. Se caracteriza por: 
Objetivos: construcción de viviendas económicas a través de un régimen de coparticipación técnica financiera entre el IVBA (que aporta la documentación técnica de los prototipos de viviendas, asesoramiento para capacitación del personal municipal y la certificación de las obras) y las Municipalidades de la Provincia de Bs. As. (que aportan terrenos dotados de infraestructura básica, la responsabilidad de la ejecución de las viviendas, la selección de los adjudicatarios y la consolidación de la deuda con los adjudicatarios con la devolución del crédito al IVBA).

Financiamiento: realizado por el IVBA a través de fondos de Rentas Generales de la Provincia.

Usuario: seleccionado por la Municipalidad de la demanda general

Proyecto: prototipos aportados por el IVBA, conjuntos habitacionales de planta baja en la primera etapa de 1967 a 1975 y de tres pisos en la segunda etapa de 1978 a 1983.

Tecnología: sistema constructivo tradicional con materiales convencionales.

Ejecución: realizada por la Municipalidad y ejecutada por empresas constructoras por Contrato de Obra o por Obras por Administración Municipal.

Resultado: 75 conjuntos habitacionales de 1958 viviendas en el ámbito jurisdiccional de los distritos municipales en el interior provincial.

Superficie promedio de cada vivienda: $40 \mathrm{~m}^{2}$ (etapa 1) y $50 \mathrm{~m}^{2}$ (etapa 2)

En 1970 se crea El Fondo Nacional de la Vivienda (FONAVI) mediante el decreto- ley 19.929, para contrarrestar el déficit habitacional y proveer viviendas económicas para sectores de bajos ingresos de la sociedad pero recién en 1972 con la ley 21.581 se determinaron y organizaron sus actividades, y en 1977 se le da mayor operatividad a través del Decreto-Ley 21581 que aumenta el ingreso del fondo al elevar el valor del gravamen del 2,5 al $5 \%$ de los aportes previonales, más tarde de impuestos coparticipados y a partir de 1995 le corresponde el 42\% del ingreso de combustibles líquidos.

Es importante destacar que el FONAVI aparece entre las Políticas Habitacionales del Estado Benefactor junto con la creación de sus instituciones, Cuenya (1992) considera la vigencia del Estado Benefactor desde 1940 a 1970, que luego se transforma a mediados de los `70 en el Estado Burocrático Autoritario con el modelo neoliberal, en el cual el FONAVI siguió operando con una política habitacional fragmentada entre los intereses de regulación económica y reducción del déficit, los de la industria constructora y los de las personas excluidas sin vivienda. 
Rodulfo (2006) ubica al FONAVI dentro de las políticas habitacionales centralizadas del Estado de Bienestar que se dan bajo el modelo sustitutivo de importaciones, con intervenciones basadas en el reconocimiento de derechos sociales.

También en 1970 se instruye un conjunto de normas legales, técnicas, y financieras que reglamentan la participación de Entidades Intermedias, públicas y privadas, identificadas en sindicatos, cooperativas, consorcios, empresas comerciales, industriales y agropecuarias promotoras de la construcción de viviendas para sus asociados y cuya concreción se cumplimenta con la suscripción de convenios entre las partes. Las entidades concurren con el aporte de terrenos, los proyectos de los conjuntos habitacionales y obras de infraestructura asumiendo también la responsabilidad de la ejecución. El IVBA evalúa la documentación, dictamina su aprobación y ejerce el control. Con el objetivo de promover la construcción de viviendas al sector de población de bajos ingresos y/o limitada capacidad de ahorro.

Se construye según las siguientes modalidades:

a) Decreto 3201/70 (vigente de 1971 a 1976): la entidad aporta los terrenos y el proyecto del conjunto habitacional, que deberá encuadrar con las especificaciones técnicas y normas de habitabilidad dispuestas por el IVBA, adecuando los costos admitidos por el IVBA, el listado de adjudicatarios, dirección ejecutiva de las obras y la documentación de subdivisión para la posterior escrituración de las viviendas.

Resultado: 5 conjuntos habitacionales de 399 viviendas (63 en el Conurbano y 336 en el interior)

b) ATEPAM por coparticipación (vigente de 1971 a 1973): los conjuntos habitacionales son ejecutados por el Sistema de Asistencia Técnica Esfuerzo Propio y Ayuda Mutua con la participación de Entidades a cargo de la administración de la obra al igual que otras delegaciones.

Resultado: 2 conjuntos habitacionales en el Conurbano de 243 viviendas.

c) Plan Federal de Viviendas -Banco Hipotecario Nacional (BHN)- (vigente de 1968 a 1973): conjunto habitacional ejecutado en Bahía Blanca, mediante un crédito otorgado al IVBA en calidad de Entidad Intermedia por el Banco Hipotecario Nacional. El proyecto es realizado por el IVBA, la licitación de la obra es realizada por el BHN y la dirección técnica está a cargo de profesionales de la ciudad a través de un concurso abierto, el IVBA adquiere los terrenos y tiene a su cargo las tareas de mensura y subdivisión, reglamento de copropiedad y escrituración de las viviendas. 
Resultado: 1 conjunto habitacional en Bahía Blanca de 495 viviendas.

Superficie promedio de cada vivienda: $65 \mathrm{~m}^{2}$ (etapa 1) y $50 \mathrm{~m}^{2}$ (etapa 2)

Así a partir de la década del '70 se da la mayor labor operativa del IVBA, con el aporte financiero de recursos nacionales a través del Plan de Erradicación de Viviendas Precarias (PEVEP) con vigencia desde 1971 a 1975, cuyo marco legal es la Res. IVBA 395/71 se caracteriza por:

Objetivos: construcción de viviendas para los sectores de más bajos recursos, posibilitando la máxima coordinación de esfuerzos entre la Nación y la Provincia.

Financiamiento: a través del aporte del gobierno nacional, por convenio firmado con la Subsecretaria de Vivienda.

Usuario: seleccionado por el IVBA entre los habitantes de la localidad.

Proyecto: conjuntos habitacionales en planta baja y tres pisos con infraestructura de servicios y aporte de terrenos realizados por el IVBA.

Tecnología: sistema constructivo tradicional con materiales convencionales.

Ejecución: realizada por el IVBA por medio de licitaciones púbicas y contratos de obras.

Resultado: 6 conjuntos habitacionales en el interior de la provincia de 501 viviendas.

Superficie promedio de cada vivienda: $68 \mathrm{~m}^{2}$

Aquí se sigue evidenciando que la intervención del IVBA responde al modelo tecnocrático normativo dada la alianza para el progreso, el desarrollismo y los gobiernos militares. Se intervenía con técnicos para erradicar a los habitantes de las villas generando núcleos habitacionales transitorios, y a quienes se les "aplicaba" planes sociales y según sus respuestas se veía si hacían méritos para acceder a las viviendas, ya que se suponía no tenían hábitos urbanos volviendo así el discurso moralizante y se intenta educarlos en ese sentido.

Según Fernández Wagner (2006) este tipo de intervención se basa en la erradicación de los asentamientos irregulares, el producto de reemplazo es la construcción de grandes conjuntos habitacionales sobre terrenos libres; financiados por fondos públicos, con muy bajo o sin recupero, la decisión y planificación la realiza el Estado en forma centralizada, y la construcción está a cargo de grandes empresas seleccionadas por licitación pública. 
En este período el IVBA se encargaba de amplias funciones, organiza la actividad constructiva, las tareas de financiación, asesoramiento integral, regularización y escrituración, es decir, realiza los estudios integrales de la obra, la factibilidad de la localización, los estudios previos, el proyecto del conjunto, de las viviendas e infraestructura, el plan de trabajo e inversión, y administraba la ejecución de la obra, la selección de los adjudicatarios, a través del área social con la difusión, las encuestas domiciliarias y los cursos de adiestramiento para el caso de mano de obra de usuarios.

Este período puede resumirse en el siguiente cuadro y gráficos que muestran las Operatorias/Programas del IVBA (cantidad y tamaño de viviendas).

\begin{tabular}{|c|c|c|c|c|c|c|}
\hline Operatoria/Programa del IVBA & Años Vigencl & Ejecución & Financiamiento & Usuario & Metros $2 \times$ Viv & Viviendas \\
\hline \multicolumn{7}{|l|}{ Período 1956 a 1976} \\
\hline Acción Cooperativa & 1957-1968 & construcción $x$ cooperativa & IVBA-rentas grales & asociados de las coop & 70 & 450 \\
\hline Sistema de Asistencia Técnica Esfuerzo Propio y Ayuda & $1961-1976$ & construcción $x$ consorcios & IVBA-rentas grales y & *asoc. Del consorcio de lad & 70 & 2,670 \\
\hline Provincia y Municipios (PYM) & 1967-1975 & construcción x munic. & IVBA-rentas grales & demanda gral del municipio & 45 & 4,212 \\
\hline Entidades Intermedias Plan Fed.Banco Hipotecario Nac. & $1968-1973$ & construcción $x$ ent.interme & Banco Hipotecario & demanda gral de Bahia Blar & 65 & 495 \\
\hline Entidades Intermedias ATEPAM x Coparticipación & 1971-1973 & construcción $x$ atepam & IVBA-rentas grales & asoc.de las entidades & 64 & 243 \\
\hline Entidades Intermedias Decreto $3201 / 70$ & 1971-1976 & construcción $x$ ent.interme & IVBA-rentas grales & asoc.de las entidades & 65 & 300 \\
\hline Plan Erradicación de Viv Precarias PEVEP & $1971-1975$ & constr.IVBA $x$ lic pub y co & IVBA-Gob.Nac. & demanda gral del municipio & 68 & 501 \\
\hline Totales del Período & & & & & 64 & 8,871 \\
\hline
\end{tabular}

Cantidad de Viviendas Construidas en el Período 1956-1976

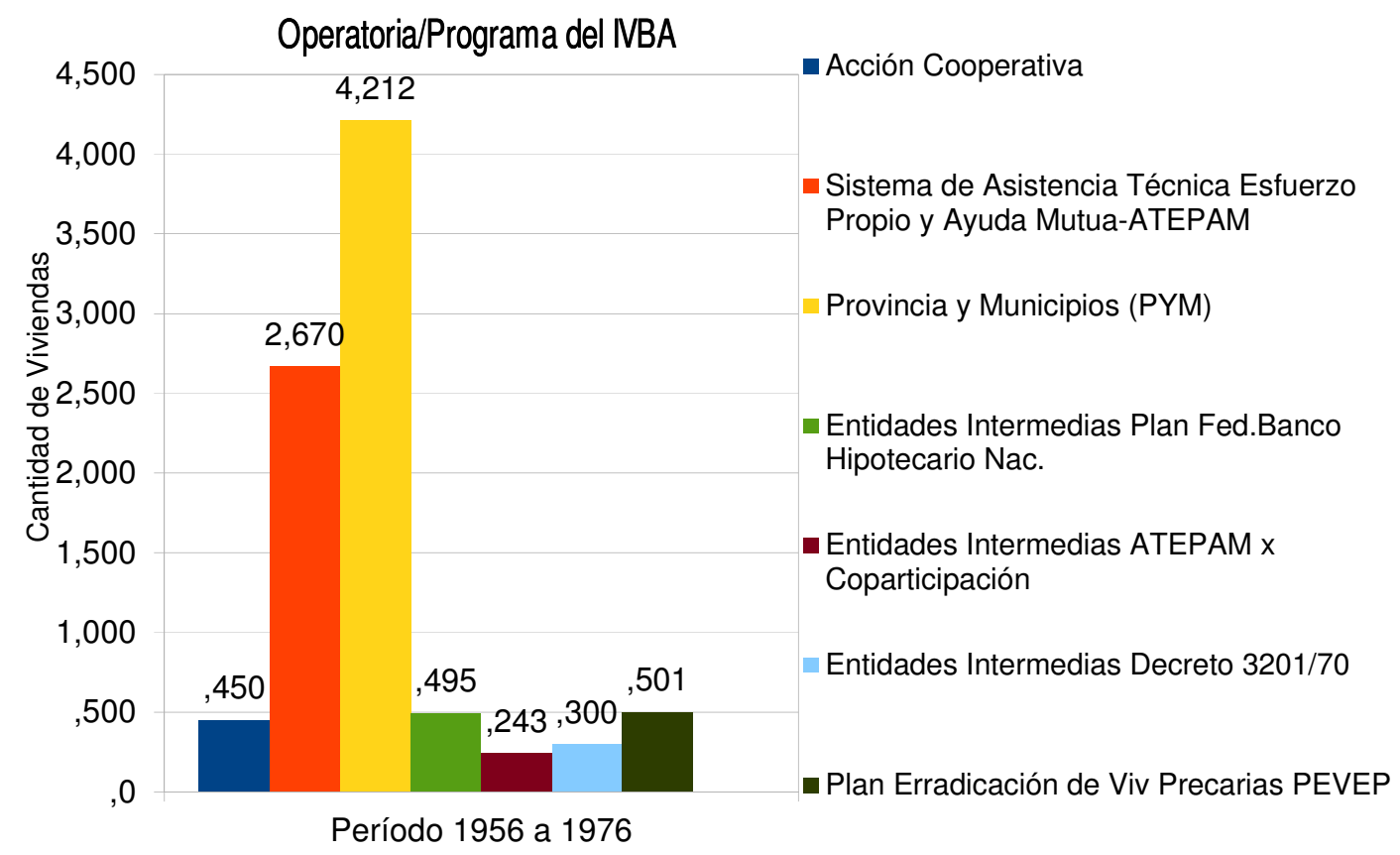


Superficie de viviendas construidas en el período 1956-1976

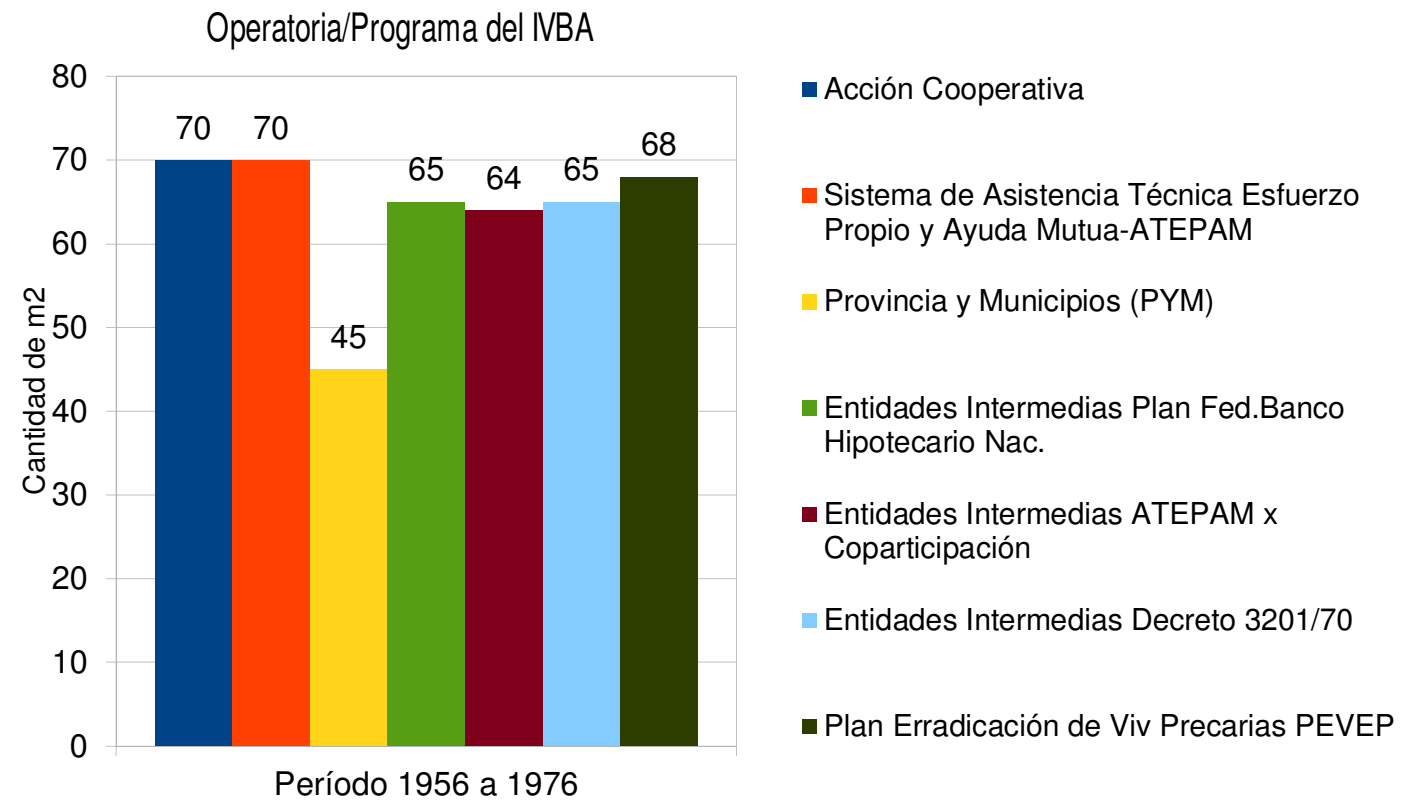

Como conclusión de este período de 1956 a 1976, se puede decir que se da la construcción de pocas viviendas, donde la Política Habitacional provincial y la gestión del IVBA responden al modelo Desarrollista del momento, la planificación tecnocrática centralizada, desarrollada durante varios gobiernos de hecho y pocos gobiernos democráticos por lo cual la característica general del periodo es la lejanía del derecho. El programa con mayor incidencia en la gestión del IVBA en este período es el Provincia y Municipios (PYM) y luego el ATEPAM, el primero si bien con mayor cantidad de viviendas pero con menor cantidad de metros por vivienda, y el segundo con una autoconstrucción dirigida sin una participación real de las personas en la gestación de los procesos de resolución de sus propias necesidades tanto como acto de producción y acto social. 


\section{Capítulo IV}

\section{EI IVBA y la Política Habitacional en el Modelo Aperturista Autoritario (1976-1983)}

En el Modelo Aperturista que va desde 1976 a 2003 existen dos etapas bien diferenciadas en lo político: la Etapa Autoritaria de 1976 a 1983 con la peor dictadura de la historia argentina caracterizada por el terrorismo de Estado, la constante violación de los derechos humanos, la desaparición y muerte de miles de personas, la apropiación de recién nacidos y otros crímenes de lesa humanidad, por lo tanto se analiza la política habitacional de esta sin relacionarla con el Derecho (cabe mencionar y reconocer los treinta y un trabajadores asesinados y desaparecidos del IVBA y del MOSP), y la Etapa Democrática de 1983 a 2003. Mientras que en lo económico se produce la crisis del Estado de Bienestar (con la reducción de su participación), y se realiza la apertura de la economía a la competencia internacional.

\section{IV.1 La Política Habitacional en la Etapa Autoritaria (1976-1983):}

\section{Contextualización de la Etapa:}

La Política Habitacional de este período coincide con el Modelo de Acumulación Económica Aperturista y la forma de Estado Burocrático Autoritario, donde según Zambrini (2011) se produce una reestructuración social en Argentina que heterogeneiza la base y homogeneiza la cúpula de la pirámide social. Se conforma una alianza entre una burguesía comercial importadora y exportadora, sectores del capital financiero, empresas de capital extranjero, algunos sectores medios, las fuerzas armadas y la jerarquía de la Iglesia quienes conforman un nuevo bloque histórico. El empleo de la fuerza y el terrorismo de Estado, imponen de manera violenta la profundización del modelo neoliberal. La política económica se basa en la escuela monetarista y la apertura económica, con la crisis del Estado de Bienestar aparecen los problemas de empleo, la subocupación y la falta de protección de quienes pierden su fuente de trabajo; la desfinanciación de las instituciones y los primeros signos de focalización de las políticas sociales que se plasman en la década del ' 90 .

Continuando con la caracterización de Torrado (1999), el gobierno surgido del golpe de Estado de 1976, adopta una estrategia de desarrollo a través de la apertura económica, y sus objetivos son:

- La vigencia de los precios de mercado como régimen básico de funcionamiento. 
- La promoción de los sectores más altamente competitivos, lo que implica la concentración del capital y la eliminación de empresas de menor productividad.

- La amplia apertura de la economía a la importación de capital extranjero de bienes de todo tipo.

- La contención del salario real como medio de controlar la inflación y de asegurar bajos costos de mano de obra a las empresas.

- El aprovechamiento de las ventajas comparativas en la exportación de bienes agroindustriales y agropecuarios aunque sin brindar estímulos especiales a estas actividades.

Para alcanzar estos objetivos se toman distintas medidas:

- La reducción de los aranceles a la importación.

- La subvaluación de la paridad cambiaria.

- La reforma financiera con un aumento en las tasas de interés real (fin del crédito subsidiado).

- La supresión de los antiguos créditos preferenciales a la industria.

- La subsidiariedad del Estado en materia económica y social, con la transferencia de parte de sus actividades (servicios públicos y empresas) a la esfera privada y el desmantelamiento del Estado de Bienestar.

- El Estado Subsidiario solo actúa donde el mercado no llega, estructurado en ideas de focalización y grupos vulnerables.

Para Torrado (1999), el ajuste en la dictadura se inicia con el golpe de Estado de 1976 que desplaza al gobierno constitucional justicialista, en medio de una crisis económica y política, liderado por un bloque dominante compuesto por el estamento militar y el segmento más concentrado del capital nacional y de las empresas transnacionales.

Las Fuerzas Armadas en el poder intentan un disciplinamiento social generalizado mediante un cambio drástico de la estructura de relaciones económicas, sociales y políticas. Se da por terminada la industrialización como objetivo del proceso de desarrollo.

Los sectores dominantes de la coalición militar, para lograr el disciplinamiento político e institucional de la clase obrera, más allá del avasallamiento de sus 
instituciones corporativas y de representación política, modifican las condiciones económicas que alentaron el desarrollo de esa clase.

El gasto y la inversión social se reducen drásticamente, y pierden poder los sindicatos. Se reduce enormemente la participación de los asalariados en el ingreso alcanzando niveles históricos de desigualdad. Decae el nivel de vida; la salud (se estanca), la vivienda (se mantiene debido al menor ingreso migratorio no por inversión social) y la educación (se retrasa en el nivel primario, se estanca en el secundario y disminuye en el superior).

Descripción de la Política Habitacional de la Etapa: en la Provincia de Buenos Aires se reforma el Ordenamiento Territorial y el Uso del Suelo derogando el DecretoLey 3487 de 1913 reemplazándolo por el Decreto- Ley 8912 de 1977 (vigente hasta 2012). A grandes rasgos se puede decir que la impronta neoliberal está presente en la misma, donde la tierra pasa a ser una mercancía más. El Estado no interviene y solo se accede a la tierra individualmente en la medida en que se pueda acceder al crédito. Este decreto-ley genera diversas facilidades para countrys y clubes de campo. Primero se genera un todo indiviso, que luego se subdivide (utilizando la ley 13512 de 1948) para poder generar las parcelas y registrar la propiedad de las viviendas. Estos mecanismos generalmente usados en los clubes de campo y barrios cerrados permiten que quienes se beneficien sean los sectores de altos ingresos ya que fija fuertes restricciones para el acceso al suelo urbano a la población en situación de pobreza, abriendo el camino a las localizaciones de urbanizaciones cerradas.

Este ordenamiento del territorio establece que la autoridad primaria en regular el uso del suelo es la órbita Municipal y si bien la intención manifiesta es brindar un marco normativo a la urbanización, buscando mayores estándares de calidad urbana, en realidad establece legalmente la división entre la ciudad formal y la informal, ya que obliga a los nuevos loteos a la dotación obligatoria de redes y a cumplir con cesiones y medidas mínimas. Esto lleva al rápido agotamiento de la oferta de lotes a bajo costo destinados a las clases más desfavorecidas, ocasionando la toma de tierras en el Conurbano sur (a finales de los '80), en la búsqueda de un lugar para vivir de los sectores populares. Asimismo, esta normativa permite la localización de clubes de campo, cristalizando en el territorio la configuración espacial que se profundizaría en los '90, estableciendo una ciudad con fuertes parámetros de segregación socio espacial. 
Siguiendo a Danani, al analizar este Decreto- Ley desde la perspectiva de los arreglos cualitativos Estado, Mercado y Familias, se ve que está claramente centrado en el mercado. El Estado se posiciona como un facilitador de los procesos de dicho mercado (en este caso en favor de los propietarios de las tierras o quienes pueden acceder a ella), respecto a las familias, especialmente el privilegio a los clubes de campo y countrys marca un sesgo hacia los sectores altos, y nada dice sobre la producción de suelo popular.

El modo de urbanización colabora con el modelo de acumulación económica aperturista, a partir de reordenar el territorio conforme a una lógica de concentración económica vinculada a los servicios financieros. A su vez, la política habitacional colabora reforzando el poder de los sectores sociales hegemónicos en dicho modelo.

Según Borthagaray (2007), este periodo es el apogeo y declinación de los grandes conjuntos habitacionales, en el nivel nacional, la reglamentación del Fondo Nacional de la Vivienda, Ley 21.581/77 (FONAVI) otorga al Estado la principal fuente de recursos genuinos para la construcción de vivienda social, desde 1977 a la actualidad. En los primeros años de esta etapa, el sector público continúa construyendo conjuntos habitacionales de gran escala y, a partir de los '80, las normas reglamentarias del FONAVI evolucionan dando paso a nuevas formas de producir vivienda, implementando categorías con diferentes niveles de terminación, precios máximos y soluciones con menor impacto en el medio urbano a partir de limitar a 250 la cantidad de viviendas a construir por cada licitación. En 1983 se operativiza el Fondo Provincial de la Vivienda (FOPROVI).

Estabilización de la Región Metropolitana de Bs. As. (1976-1989): esta etapa es caracterizada por Calello (2000) por la concentración de capitales, guiados por el sector financiero y las actividades terciarias improductivas que tienen lugar en la región. La crisis del modelo industrializador y el Estado de bienestar deja a vastos sectores de la población fuera de los mercados laborales y de los servicios e infraestructura urbana mínimos.

A partir de 1976, la política habitacional se transforma por medio de la acción u omisión deliberada de diferentes factores: el aliento a la especulación concentrada, el 
control al sector popular con intervenciones urbanas excluyentes a través de los mecanismos de mercado, la erradicación de villas y los desalojos.

En esta etapa, para Yujnovsky (1984) la vivienda no es un derecho, es una lucha por el derecho ligada a la lucha más general del pueblo argentino para lograr una sociedad democrática en donde las políticas habitacionales se implementen en función de las necesidades de la población y la asignación de recursos se haga en términos de solidaridad humana y no del lucro y privilegio de una minoría.

Para Oszlack (1983), durante el período 1976-1983, las políticas habitacionales implementadas por el gobierno militar transforman drásticamente la conformación socio espacial de la región, mediante las relocalizaciones industriales, la creación del cordón ecológico, la construcción de autopistas junto a las expropiaciones de bienes, la liberación general de alquileres y la erradicación de villas de emergencia de la Capital Federal y su posterior traslado al Conurbano Bonaerense.

Según Calello (2000), el complejo metalmecánico es desarticulado, las empresas transnacionales y los grupos económicos locales se convierten en el polo dinámico de la acumulación, subordinando a los capitales nacionales y las PYMES. Las actividades productivas principales son las manufacturas de origen agropecuario y las extractivas.

Las políticas represivas del Estado, la apertura externa de la economía y la reforma cambiaria (reducción de los salarios e incremento de la deuda externa) profundizan y heterogeneizan la pobreza, con la pauperización de las clases medias, dando surgimiento a nuevas formas de ocupación del suelo como los asentamientos planificados.

Los cambios urbanos producidos en el ámbito de la Capital Federal van a impactar fuertemente en la provincia de Buenos Aires, principalmente en el Conurbano bonaerense. Según Torres (1993), los instrumentos de ordenamiento territorial durante el régimen militar imponen cambios urbanos drásticos como el Nuevo Código de Ordenamiento Urbano de la ciudad de Buenos Aires de 1977 que modifica el tejido urbano, disminuye sustancialmente las alturas a las que es posible construir, limita el crecimiento poblacional, y erradica las industrias del radio de la Capital Federal. 
Para Fernández Wagner (2008), la formación de los asentamientos en el Conurbano es el resultado de la erradicación de villas en la Capital Federal, como así también producto de la construcción de autopistas y estacionamientos, que demuelen parte del parque habitacional central, y la nueva Ley de locaciones urbanas que descongela los alquileres y expulsa muchos inquilinos del centro de la ciudad.

Profundizando con Pírez (1994), el inicio del Modelo Aperturista con el golpe militar del '76 produce una fuerte desindustrialización y redistribución regresiva del ingreso, el crecimiento en los sectores no productivos (servicios y transporte) y especialmente las finanzas, el aumento en la participación de sectores más concentrados y la consolidación de los grupos económicos y empresas transnacionales, el deterioro de la situación de los asalariados y las pymes, lo que significa una fuerte concentración de la riqueza disminuyendo el ingreso de los asalariados. Las medidas desarrolladas en este período producen efectos en las condiciones de vida de la ciudad metropolitana:

- La eliminación del congelamiento de alquileres urbanos, donde los inquilinos de clase media y media baja abandonan los lugares donde residen y van hacia la periferia metropolitana o a los inquilinatos y hoteles de la Capital Federal.

- La circular 1050 del Banco Central indexa los contratos de compra venta de tierras en los que están los loteos populares, esto hace que a los compradores se les dificulte aún más afrontar los pagos.

- La ejecución autoritaria y represiva de un plan de erradicación de villas miseria.

- El Código de Planificación Urbana y la Ley de Uso del Suelo, que desplazan población hacia la periferia metropolitana, y encarecen los loteos y la disminución de su oferta para los sectores de menores recursos.

- La construcción de autopistas y estacionamientos que expulsan poblaciones a la vez que favorecen la opción del transporte individual y la apropiación de la renta en los terrenos céntricos.

- La erradicación de industrias en los partidos de la primera corona del Gran Bs. As.

- El fin del subsidio al transporte.

- La segregación territorial metropolitana: en la capital se concentran los sectores medios y medios altos, y en el Gran Bs. As. en su zona Sur y Oeste los sectores de menores recursos.

En esta etapa de política urbana neoliberal, la Política Habitacional reorienta los recursos a los sectores de mayor concentración de ingresos y menor necesidad de 
vivienda. A su vez, la asignación de recursos a los sectores concentrados permite una dilapidación y derroche de recursos por parte de los sectores menos necesitados que incentivan el gasto superfluo de la infraestructura urbana y edilicia. La respuesta habitacional tiene un descenso masivo de las condiciones habitacionales y del acceso a la ciudad de grandes franjas de los sectores medios y bajos.

\section{IV.2.- Gestión del IVBA en la Etapa Autoritaria del Modelo Aperturista (1976- 1983)}

Como ya se mencionó, por el Decreto Ley 9573 de 1980, se crea Ley Orgánica del Instituto de la Vivienda que define su finalidad de:

- Ejecutar la política habitacional que al efecto establezca el Poder Ejecutivo en el ámbito provincial,

- Actuar dentro de la materia de su competencia como asesor del Poder Ejecutivo,

- Constituir el organismo de aplicación del Decreto- Ley nacional 21581/77 (de FONAVI) o la que la sustituya en el futuro, a través del cual se canalicen los recursos destinados al cumplimiento de los planes habitacionales en el ámbito de la provincia de Bs. As.

Este Decreto-Ley 21581/77 implementa el Régimen del Fondo Nacional de la Vivienda (FONAVI), que ya había sido creado en 1970 durante el Estado Benefactor, e instruye un sistema operativo de aporte financiero a las provincias para la atención del déficit habitacional imperante. Se centraliza en la entonces Secretaría de Estado de Desarrollo Urbano y Vivienda de la Nación, el manejo y distribución de los fondos nacionales coparticipados, como también la fijación de un cuerpo normativo de reglamentaciones sociales, económicas y jurídicas, de diseño urbano y habitacional, tecnológicas, de costos de aplicación y prescripciones operativas de cumplimiento obligatorio para la obtención de aptitudes técnicas y financieras requeridas por las jurisdicciones provinciales.

\section{Para el cumplimiento de sus fines el IVBA tiene las siguientes atribuciones:}

- Administrar los fondos asignados;

- Realizar estudios y proyectos de los planes habitacionales que encaren los municipios o la Provincia;

- Suscribir convenios con organismos municipales, provinciales, nacionales e internacionales, personas o entidades públicas o privadas; 
- Concertar con las distintas municipalidades de la provincia, la estructuración de un régimen permanente de coparticipación técnica y cooperación financiera, que posibilite a través de la entrega de recursos a las comunas, el empleo de toda capacidad de ejecución en materia habitacional;

- Realizar el censo provincial de vivienda, a fin de mantener actualizada en forma permanente la documentación que le permita desempeñar correctamente su misión.

Así el Decreto Ley Orgánica del Instituto de la Vivienda de la Provincia de Bs. As. N9573/80 vigente hasta la actualidad, confiere la plena autarquía de derecho público al organismo y su carácter de ejecutor de la Política Habitacional establecida por el Poder Ejecutivo Nacional y ejecutor de los fondos nacionales y provinciales de vivienda (FONAVI y FOPROVI); manteniendo sus relaciones con el poder ejecutivo por intermedio del Ministerio de Obras Públicas y siendo la Subsecretaría de Urbanismo y Vivienda de la Nación quien centraliza la aprobación de los proyectos y su financiación.

A través del FONAVI, el IVBA recibe 1.477 viviendas emplazadas en el Conurbano Bonaerense para su regularización dominial y/o finalización; y le permite al Instituto acceder a un financiamiento superior al que recibía cuando los aportes eran de Rentas Generales de la Provincia. También se reciben varias obras iniciadas por el Banco Hipotecario Nacional paralizadas o legalmente comprometidas para ser terminadas bajo este régimen.

A partir de este momento, dada la normativa y los mayores recursos financieros, la actividad centralizadora del IVBA se concentró en el análisis, estudios y definiciones de localizaciones urbanas y rurales basadas en el uso territorial de suelo regido por la Ley $8912 / 77$, elaboración de proyectos de prototipos, conjuntos habitacionales y obras básicas de infraestructura y equipamientos mínimos, convocatorias a licitaciones públicas y/o compulsas de precios, contratación, ejecución y control de las obras, estudios sociales para la selección de adjudicatarios y entrega de las viviendas, y las gestiones para su posterior escrituración.

\section{Operatorias de Vivienda de esta etapa (en conjuntos habitacionales):}

Operatoria FONAVI: 28.214 viviendas.

Operatoria FOPROVI: 758 viviendas.

Operatoria Provincia y Municipios (PYM): 1.558 viviendas. 
Operatoria Entidades Intermedias Decreto 3201/70: 99 viviendas.

Operatoria Alborada: 570 viviendas.

La Operatoria Alborada vigente de 1974 a 1978 se caracteriza por:

Objetivos: construcción de viviendas para los sectores de más bajos recursos, en concordancia con lo dispuesto por el gobierno nacional para la concreción de 17000 unidades habitacionales en todo el territorio a través de un Plan Trienal (decreto 776/73) y formalizado por Acta Compromiso del año 1974.

Financiamiento: del IVBA a través del aporte del gobierno nacional, con intervención de la Subsecretaria de Vivienda, supervisora del programa.

Usuario: seleccionado por la Municipalidad según demanda general de la localidad.

Proyecto: conjuntos habitacionales en planta baja y dúplex con infraestructura de servicios realizados por el IVBA con la colaboración de equipos técnicos municipales.

Tecnología: sistema constructivo tradicional con materiales convencionales.

Ejecución: realizada por el IVBA por medio de licitaciones púbicas y contratos de obras.

Resultado: 7 conjuntos habitacionales en el interior de la provincia de 576 viviendas.

Superficie promedio de cada vivienda: $68 \mathrm{~m}^{2}$.

La Operatoria FONAVI con vigencia de 1976 a 1996, y cuyo marco legal es la ley $21581 / 77,24464 / 95,11663 / 95$ y el decreto $187 / 96$, se caracteriza por:

Objetivos: acudir en ayuda de los sectores de bajos recursos económicos con soluciones habitacionales de la demanda general o de las necesidades particulares de Entidades sin fines de lucro.

Financiamiento: del IVBA por medio del Fondo Nacional de Vivienda (a través de la Secretaría de Urbanismo y Vivienda) por medio certificados de obra descontados del Banco Hipotecario Nacional

Usuario: selección según demanda general y/o adjudicatarios propuestos por las Entidades Intermedias.

Proyecto: conjuntos habitacionales de viviendas individuales y colectivas con infraestructura de servicios y equipamiento comunitario realizados por el IVBA y/o las Entidades intervinientes con la colaboración y supervisión del IVBA.

Tecnología: sistema constructivo tradicional con materiales convencionales y sistemas industrializados aprobados. 
Ejecución: realizada por el IVBA por medio de licitaciones púbicas y contratos de obras.

Resultado: 304 conjuntos habitacionales de 72244 viviendas (45230 viviendas en el Conurbano y 27014 viviendas en el interior de la provincia).

Superficie promedio de cada vivienda: $62 \mathrm{~m}^{2}$

La Operatoria FOPROVI con vigencia de 1980 a 1996, y cuyo marco legal es la ley Orgánica del IVBA 9573/80, se caracteriza por:

Objetivo: acudir en ayuda de los sectores de bajos recursos económicos con soluciones según las necesidades generales y emergencias habitacionales detectadas en la Provincia.

Financiamiento: IVBA por medio del Fondo Provincial de Vivienda creado a tal efecto (constituido también con aportes del FONAVI).

Usuario: selección según demanda general y/o el usuario particularizado según el programa.

Proyecto: conjuntos habitacionales de viviendas individuales y colectivas con o sin infraestructura de servicios y equipamiento comunitario realizados por el IVBA.

Tecnología: sistema constructivo tradicional con materiales convencionales y sistemas industrializados aprobados.

Ejecución: realizada por el IVBA por medio de licitaciones púbicas y contratos de obras.

Resultado: 89 conjuntos habitacionales de 5342 viviendas (1029 viviendas en el Conurbano y 4313 viviendas en el interior de la provincia).

Superficie promedio de cada vivienda: $52 \mathrm{~m}^{2}$

Esta etapa puede resumirse en el siguiente cuadro y gráficos que muestran las Operatorias/Programas del IVBA y su cantidad de viviendas y tamaños.

\begin{tabular}{|c|c|c|c|c|c|c|}
\hline Operatoria/Programa del IVBA & & & & & & \\
\hline Etapa 1976-1983 & Años Vigenc & Ejecución & Financiamiento & Usuario & Metros $2 \times$ Viv & Viviendas \\
\hline FONAVI & 1976-1983 & constr.IVBA $x$ lic pub yco & IVBA-FONAVI & demanda gral y/o asoc.de e & 62 & 28,214 \\
\hline FOPROVI & 1980-1983 & constr.IVBA $x$ lic pub ycd & IVBA-FOPROVI & demanda gral munic.o segú & 52 & 758 \\
\hline Provincia y Municipios(PYM) & 1978-1983 & construcción x munic. & IVBA-rentas grales & demanda gral del municipio & 45 & 1,558 \\
\hline Entidades Intermedias Decreto 3201/70 & 1971-1976 & construcción $x$ ent.interme & EIVBA-rentas grales & asoc.de las entidades & 65 & 99 \\
\hline Alborada & 1974-1978 & constr.IVBA $x$ lic pub y co & JIVBA-Gob.Nac. & demanda gral del municipio & 68 & 576 \\
\hline Totales del Período & & & & & 58 & 31,205 \\
\hline
\end{tabular}


Cantidad de viviendas construidas en la etapa 1976-1983

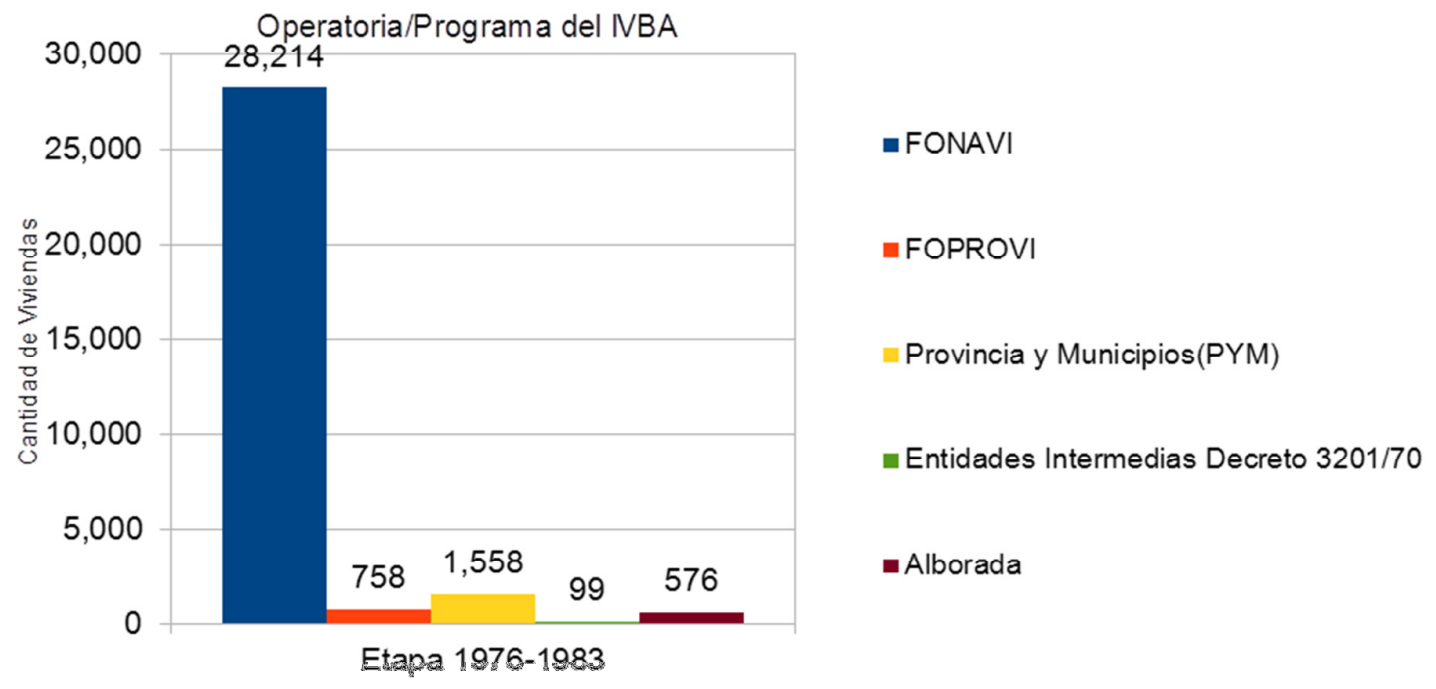

Superficie de viviendas construidas en la etapa 1976-1983

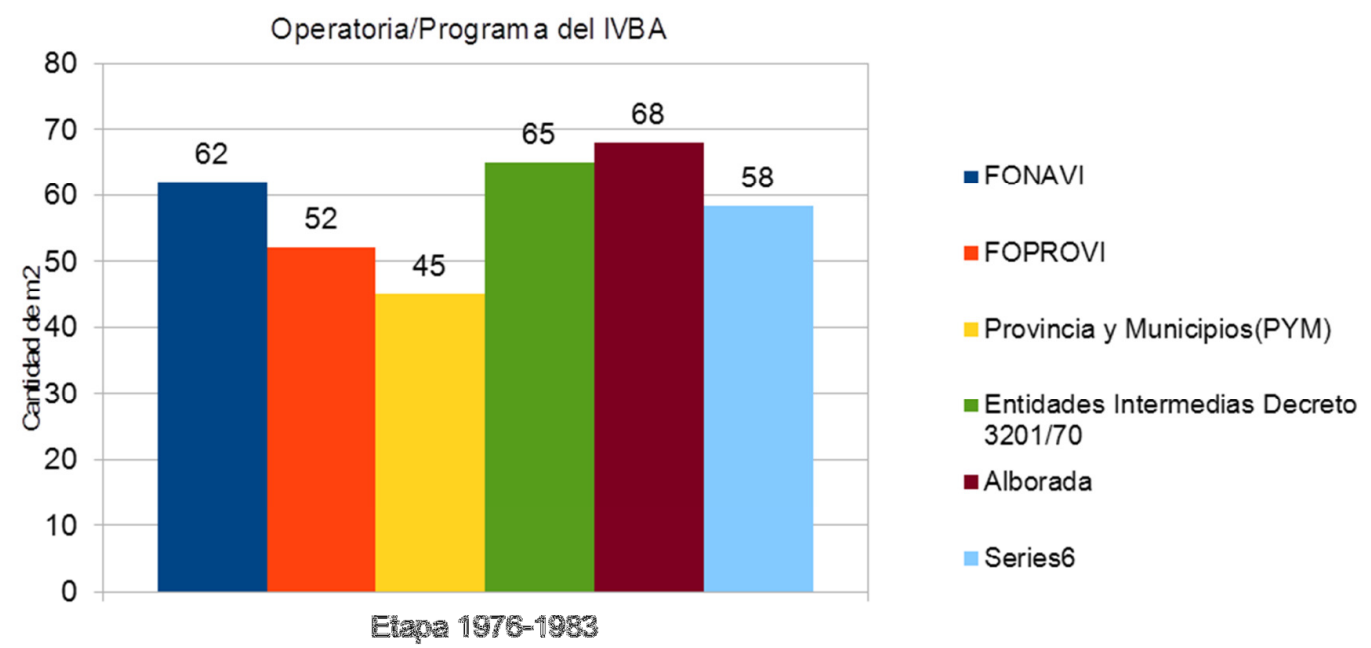

Como conclusión de esta etapa autoritaria de 1976 a 1983, en el Modelo de Acumulación Aperturista, la Política Habitacional del IVBA a través de la Operatoria FONAVI es la que más cantidad de viviendas produce con una ideología que no se apoya en el derecho sino en el de ocultar los asentamientos y villas de emergencia como así también desarticular la organización social de sus habitantes, ubicándolas además en los márgenes o periferias. 


\section{Capítulo V}

\section{EI IVBA y la Política Habitacional en el Modelo Aperturista Democrático}

(1983-2003)

\section{V.1. La Política Habitacional en la Etapa Democrática (1983-2003) Contextualización de la Etapa:}

Para Zambrini (2010), el Estado Democrático, que retorna en 1983, se caracteriza en la década del '90 por las reformas estructurales que modifican el marco regulatorio que enmarca el proceso de acumulación de apertura de la economía a la competencia internacional y la reducción del rol del Estado (privatizaciones y flexibilización laboral, entre otras medidas).

Para Svampa (2005), el Modelo Aperturista (1983-2003) pone en marcha un programa neoliberal que se caracteriza por una serie de medidas de índole política, económica y social:

- El Estado asume la desregulación de la economía como principio pautado por el Consenso de Washington (CW) y como directriz de sus políticas.

Stewart (1998) se refiere a dicho "consenso", al nuevo modelo económico que implica y enumera 10 componentes del mismo tales como: disciplina fiscal, tasas de cambio unificadas, apertura comercial, apertura financiera, reforma fiscal, reorientación de las prioridades del gasto público, inversión extranjera directa (eliminación de barreras), privatización de empresas estatales, desregulación (eliminación de barreras a la entrada y restricciones a la competencia) y resguardo del derecho a la propiedad.

Estas políticas implican dos grandes cambios, un papel muy reducido del Estado en la economía y un papel mayor para el mercado, y la eliminación de la protección a los productores locales otorgándoles a los inversores extranjeros un tratamiento de igualdad.

Así mismo, dichas políticas no redundan en mejoras de crecimiento económico, empleo y reducción de la desigualdad en los países latinoamericanos.

- Se desmantela el Estado Benefactor y termina con la vinculación necesidadderecho.

- Se transforman las reglas de juego económicas con la paridad entre el peso y el dólar, la restricción de la emisión monetaria, la reducción de barreras aduaneras, la liberación del comercio exterior y el aumento de la presión fiscal.

- Se suprime el control del Estado en la economía a favor de las reglas del mercado. 
- Se libera la inversión extranjera en el país y las importaciones.

Este modelo impone una modernización excluyente con la dualización de la economía y la sociedad. Aumenta la productividad con escasa generación de empleo y deterioro de las condiciones laborales, a la vez que genera problemas para competir a las pequeñas y medianas empresas por la implementación del plan de Convertibilidad que sostiene la paridad de un peso a un dólar. Hacia finales de 1995 se profundiza la pobreza y la desocupación iniciando la recesión que hace colapsar dicho modelo.

La reestructuración del Estado, la reducción del gasto, la descentralización administrativa y el traslado de competencias (en salud, educación y vivienda) al nivel provincial y municipal sin la correspondiente transferencia de recursos, la desregulación y las privatizaciones que modifican la calidad y el alcance de los servicios que estaban en manos del Estado Nacional, generan una nueva estructura social con polarización y aumento de las desigualdades.

La desregulación de los mercados y la flexibilización laboral provocan una alta tasa de desempleo, por lo que se trata de contener la pobreza vía distribución masiva de asistencia alimentaria y planes sociales a las poblaciones más afectadas y movilizadas. Aumenta el poder de policía, aplicando políticas focalizadas a la peligrosidad y momentismo social.

Se produce una territorialización de las clases populares (villas de emergencia y asentamientos) visibles en el empobrecimiento y segregación social espacial, el trabajo doméstico y la labor comunitaria de las mujeres para sustentar sus hogares; mientras que la clase media superior se autosegrega en countrys y barrios privados. En los territorios se produce el nacimiento de los primeros movimientos sociales que resisten en la calle a las expresiones del Estado Neoliberal, con movilizaciones, cortes de rutas y calles. Como respuesta a estas manifestaciones sociales, este Estado responde con represión y da lugar a la judicialización de la protesta social.

El paradigma neoliberal caracteriza al Modelo Aperturista y sustenta la retracción del Estado, basado en la libertad de mercado (desregulación), la preeminencia del capital privado sobre el público, el desmantelamiento de las instituciones del Estado de Bienestar, las privatizaciones, la flexibilización, la descentralización; y la reducción del gasto público. Esto repercute directamente en la Política Habitacional reduciendo la inversión en el sector. Se dilapida la tierra pública para construcción de emprendimientos privados 
(canchas de golf, hipermercados, barrios cerrados) y el Estado además de perder la capacidad regulatoria en general, específicamente deja de ser también propietario del suelo.

Para Torrado (1999) esta etapa (1983-2003) corresponde al ajuste en democracia, con la guerra de Malvinas en 1982 que termina con el gobierno militar y asume el gobierno constitucional el Dr. Alfonsín. La situación económica caótica, el déficit fiscal, las presiones inflacionarias, las vicisitudes de la transformación democrática, y la irracionalidad política, resultan en brotes hiperinflacionarios que repercuten en los sectores populares y obligan a la entrega anticipada del poder en 1989 al Dr. Menem que gobierna hasta 1999, dándole continuidad al modelo aperturista. Con el Plan Convertibilidad se controla la inflación y se da el crecimiento del producto bruto nacional, al menos algunos años, y se entra en una gran recesión en 1998 hasta 2001.

A los inconvenientes del modelo aperturista se le suma la vulnerabilidad externa de la economía, derivada de las restricciones que impone al crecimiento y la imposibilidad de generar un superávit de la balanza de pagos para hacer frente a los exorbitantes servicios de la deuda externa en expansión.

En el plano social se desmantela el Estado de Bienestar. Se introducen cambios en la legislación laboral que reducen la estabilidad en el empleo, promoviendo el empleo legal precario, tolerando el empleo en "negro", bajando costos de contratación y de despido, y aliviando las responsabilidades del empleador frente a los accidentes de trabajo y quiebras empresarias. Las políticas sociales se ven afectadas negativamente por la degradación de las fuentes de financiamiento y por cambios en la administración, el régimen de acceso y el tipo de "beneficios".

En 1999 asume el poder una alianza de partidos que lleva como presidente al Dr. De La Rúa que continúa con el ajuste y la orientación aperturista hasta su renuncia anticipada en 2001. El empeoramiento de las condiciones laborales y de bienestar, muestra una estrategia concentradora, y excluyente, con gran aumento de la pobreza crítica y deterioro del bienestar de los más débiles. 


\section{Descripción de la Política Habitacional de la Etapa:}

Esta etapa se caracteriza por las políticas neoliberales que producen el debilitamiento del Estado en el nivel nacional, los gobiernos locales comienzan a abordar la cuestión del suelo urbano, la infraestructura y la vivienda.

La Política Habitacional de la década del '90 está caracterizada por una fuerte impronta neoliberal en el aspecto político-institucional, observándose por parte del Estado el abandono de funciones que históricamente le fueron propias, a través de la: descentralización, tercerización, consecuente desmembramiento de sus estructuras orgánicas y venta de sus principales activos a capitales privados, en su mayoría extranjeros.

A esta etapa según Fernández Wagner (2007) corresponden las Políticas

Habitacionales de Tercera Generación, de la década del '90, que por una parte implican la influencia del capital financiero global y la facilitación como dispositivo en el marco del Consenso de Washington; mientras, por otra parte, el incremento de la pobreza, que estas políticas reproducen, se compensa con intervenciones focalizadas en los asentamientos informales, en pos de lograr su urbanización.

Rodulfo (2004) define a la Política Habitacional de la década del '90 como "descentralizada" hacia las provincias y estas hacia los gobiernos locales. Ya que a partir de la década del '90, el Estado se ausenta de la esfera social y en el contexto de las políticas neoliberales, el desempleo estructural y la pobreza, es la sociedad civil con los gobiernos locales quienes se hacen cargo de las soluciones habitacionales focalizadas en la pobreza extrema.

Prima el principio liberal de subsidiariedad que dispone que un asunto debe ser resuelto por la autoridad (normativa, política o económica) más próxima al objeto del problema, por lo tanto nada que una entidad pueda asumir lo debe asumir una entidad superior. Así el Estado transfiere a las jurisdicciones inferiores (como así también a la comunidad, y ésta a la familia; y la familia al sujeto).

A partir de 2000 se produce la crisis del modelo neoliberal entrando el país en una debacle que tiene su punto culminante en diciembre de 2001. Las provincias destinan sus fondos FONAVI para cubrir déficit en otras cuentas provocando que el sistema quede desfinanciado y paralizado. 
Fernández Wagner (2008) define la última etapa del menemismo como una agonía en términos políticos y sociales, llegando al poder De La Rúa en 1999 con ajustes y recortes salariales para intentar sostener la convertibilidad con el canje de bonos que pone en su punto más crítico el endeudamiento externo. La recesión profundiza la desindustrialización y la baja competitividad nacional, la crisis afecta el financiamiento del Estado, en el plano social los bajos ingresos, el aumento de la pobreza, la indigencia y la nueva pobreza en sectores medios provoca a fines de 2001 un estallido social que precipita la caída del presidente y la llegada de Duhalde como presidente interino tras una semana de crisis en la que se sucedieron cinco presidentes. Se lleva adelante una fuerte devaluación mientras proliferan las asambleas barriales, las ollas populares y los comedores. Los sistemas públicos de asistencia social no dan abasto para paliar el hambre y la falta de ingreso monetario. La convulsión social va lentamente dando paso a una incipiente reactivación económica derivada de las ventajas comparativas producidas por la devaluación, antesala del proceso de reindustrialización llevado adelante a partir de 2003 cuando llega a la presidencia Néstor Kirchner.

\section{La Inserción Global de la Región Metropolitana de Bs. As. (1989-2003)}

Calello (2000) caracteriza este período por los procesos a los que induce la inserción a la economía global, tales como las políticas de ajuste estructural que se implementan bajo imposición de organismos financieros internacionales como el Fondo Monetario Internacional y el Banco Mundial. Incluyen medidas como la desregulación y apertura de las economías nacionales, la reducción del rol del Estado como agente económico y de regulación, de prestador de servicios de consumo colectivo y en su función de compensador social de las fallas del mercado. Por lo tanto el impacto de la globalización, la privatización y desregulación de los servicios urbanos públicos y las inversiones extranjeras directas orientadas a los sectores de infraestructura $y$ comunicaciones definen un sentido poco productivo para la región.

Según Cicolella (1999) la provincia de Buenos Aires muestra una organización fracturada y dual del espacio urbano, que presenta por un lado los restos del espacio forjado por la lógica taylorista-fordista caracterizado por sus condiciones de deterioro y desestructuración socio territorial; y por otro lado, los nuevos espacios centrales y periféricos responden a la lógica posfordista, posmoderna y posindustrial, donde la forma espacial tentacular se redefine hacia un archipiélago urbano donde se concentran los espacios de gestión, actividades financieras y comerciales. Esto da lugar un 
afincamiento suburbano en clubes de campo y barrios privados de familias de sectores medios y altos en zonas antes consideradas pobres, potenciadas por la conclusión del Acceso Norte, Oeste, la Autopista Buenos Aires.- La Plata, la autopista a Cañuelas y la rehabilitación del Tren de la Costa.

Para Torres (1993), los cambios en la estructura urbana provocados por la crisis de la década del '80 se puede ejemplificar con:

- El pasaje de la villa miseria al asentamiento (que trata de no diferenciarse del trazado urbano regular para favorecer su futura regularización e incorporación a la ciudad),

- Los procesos de suburbanización residencial de los grupos de altos ingresos en los countrys,

- El acrecentamiento del deterioro central o tugurización (los hoteles, pensiones y conventillos),

- El crecimiento de las villas de la Capital Federal,

- La ocupación de viviendas desocupadas en áreas centrales.

A mediados del '80 se perciben los efectos de las políticas del período anterior, empobrecimiento de la población y cambios en la distribución territorial de la población. Con la democracia en 1983 la población en situación de mayor pobreza registra tres formas de hábitat: las villas, las tomas de propiedades públicas o privadas, y los inquilinatos y hoteles en condiciones de hacinamiento y pobreza.

Pirez (1994) concluye que Buenos Aires metropolitana se caracteriza por ser una ciudad desigual socialmente y que se distribuye en dos sectores territoriales fundamentales, la ciudad central en la Capital Federal y el conurbano en el Gran Buenos Aires. En la primera hay una fuerte presencia de sectores medios y altos, y en la segunda de sectores populares (excepto en la zona Norte).

Estas desigualdades se dan en medio de una crisis de infraestructura y servicios colapsados, condiciones sanitarias deficitarias del medio ambiente; que implica además de la falta de trabajo y bajos ingresos, viajes de varias horas en medios de transporte atestados, falta de seguridad, de atención en los servicios de salud y de educación pública, además de convivir con la basura y contaminación, entre otras cosas. 
En la etapa correspondiente a la inserción global del área metropolitana, se produce un retroceso apreciable en los niveles de efectivización del derecho a la vivienda y a la ciudad de vastos sectores radicados en el Conurbano bonaerense. La fragmentación de la sociedad tiene su reflejo en la ciudad compacta que va dando lugar a una ciudad dispersa.

En este momento, cabe la reflexión de autores como Mangada (2008) quien defiende la ciudad compacta relacionada a un desarrollo urbano continuo y denso (tanto físico como funcional mezclando formas y alturas en un territorio no parcelado y menos segregado), lo cual implica una interrelación de actividades, y la proximidad de la vivienda al comercio, al teatro, al parque, al colegio, como así también la austeridad en el uso de las energías necesarias para su funcionamiento. Frente a esta ciudad compacta aparece la ciudad dispersa, producida por la aleatoriedad de las actividades y las viviendas, los centros comerciales, las fábricas o los colegios que invaden el territorio de forma extensiva e indiscriminada, arruinando recursos naturales en un modelo despilfarrador de energía. Los desarrollos residenciales en torno a las ciudades, los centros comerciales y campos de golf, mencionados anteriormente son algunos ejemplos de la ciudad dispersa. Este autor, defiende la ciudad compacta, existente y consolidada, rehabilitándola y modernizándola, haciendo ciudad en la ciudad, aprovechando los vacíos (existentes o potenciales) o proyectando un crecimiento ponderado para completarla.

En esta etapa la Política Habitacional es focalizada ante la emergencia respondiendo a la ideología del modelo imperante y tendiente a evitar el conflicto social, lo cual implica un gran retroceso en las soluciones habitacionales de los sectores más desprotegidos; mostrando así un claro retroceso en la efectivización del Derecho a la Vivienda y a la Ciudad.

\section{V.2.- Gestión del IVBA en el Modelo Aperturista en la Etapa Democrática (1983- 2003)}

Se puede realizar en esta etapa una división en dos sub-etapas en cuanto a las Operatorias del IVBA: un momento de centralización que va de 1983 a 1992 y uno de descentralización que va de 1992 a 2003. 
Retomando a Igarzabal (1999), a partir de 1983 con el retorno al Estado de derecho se adecuan las estrategias políticas para una flexibilización operativa, se promulga la ley 10346 mediante la cual se amplió la capacidad operativa del IVBA autorizando la aplicación de convenios de coparticipación financiera con entidades públicas, privadas o mixtas, la ley 10352 que perfeccionó la creación del FOPROVI con la asignación de un porcentaje a la recaudación del impuesto inmobiliario para la financiación de las viviendas y la ley 10354 que viabilizó la contratación de un crédito con el Banco Provincia para la construcción de viviendas para familias residentes en zonas afectadas por las inundaciones.

En 1987 se implementan, en coexistencia con las operatorias FONAVI, algunos programas que intentan profundizar las relaciones con los gobiernos locales y con movimientos y organizaciones de pobladores barriales (Programas denominados ProCasa y Pro-Tierra), transfiriendo la responsabilidad constructiva a los Municipios (instrumentando auditorias en lugar de las inspecciones de obras, en sólo cuatro certificaciones y liquidaciones financieras, estructuradas en un anticipo de $25 \%$ y tres pagos más del mismo importe).

A partir de la década del '90 en el marco del modelo neoliberal, donde se produce la privatización del Banco Hipotecario Nacional y la modificación de la ley FONAVI, se descentralizan los recursos hacia los Institutos de la Vivienda Provinciales, que sumado al achicamiento del gasto, la desregulación de la economía y la liberalización de los mercados llevan a la deconstrucción del Derecho a la Vivienda, reinstaurándose el principio liberal de subsidiariedad y de responsabilidad individual en el acceso a la vivienda, lo que implica el abandono de la responsabilidad compartida y los principios de solidaridad social.

Con la descentralización de los fondos a los institutos provinciales se produce una focalización sobre los problemas locales, diversificando las operatorias para dar respuesta a las diferentes demandas. La construcción de viviendas tipo "llave en mano", va cediendo paso a nuevas "soluciones habitacionales", como los emprendimientos de autoconstrucción dirigida y de vivienda progresiva o vivienda semilla.

Así se sanciona la ley 23966/91 que modifica el Decreto-Ley 21581/77 del FONAVI, disponiendo la descentralización del manejo y distribución de los recursos financieros 
nacionales por parte de la Secretaría de Vivienda y Ordenamiento Ambiental, mediante una distribución automática a los Institutos de la Vivienda Provinciales de todo el país, sustituyendo el mecanismo constitutivo del fondo basado en aportes previsionales, por un porcentual de la recaudación del impuesto sobre los combustibles líquidos y gas natural.

Con ello se realiza la independencia de los Institutos de la Vivienda Provinciales del órgano administrador nacional, ponderándose las autonomías provinciales, quedando en el ámbito de cada jurisdicción el otorgamiento de aptitudes técnicas y financieras de los proyectos y las facultades reglamentarias que los organismos ejecutores dispongan para cumplir con los objetivos de sus respectivos programas habitacionales, concretándose esto con el Acuerdo entre el Gobierno nacional y los gobiernos provinciales ratificado por el Congreso en 1992 mediante la Ley 24130.

Desde ese momento, la denominada Subsecretaria de Vivienda de la Nación y los Institutos Provinciales de Vivienda coparticipan para lograr el Sistema Federal de Vivienda y el Consejo Nacional de Vivienda a través de la ley 24464 sancionada en 1995. Así, la Subsecretaria tiene el rol de organismo auditor y responsable del cálculo y comunicación a los Institutos de las transferencias automáticas de los fondos a través del Banco Hipotecario Nacional. El IVBA se adhiere a esta ley en 1995 mediante el dictado de la Ley provincial 11663 y el decreto reglamentario 187 de 1996, mediante el cual se fijan pautas para la regularización dominial de inmuebles y el otorgamiento de escrituras, con la intervención del Colegio de Escribanos de la Provincia de Buenos Aires.

En este período muchas de las tareas que antes realizaba el IVBA las comienzan a realizar los Municipios y las Entidades Intermedias como la selección de las personas adjudicatarias, y el proyecto de las viviendas (por ejemplo en la Operatoria de Autogestión constructiva), reservándose el IVBA las tareas de asesoramiento $\mathrm{y}$ supervisión. Es decir, el IVBA ahora solo controla la obra (los materiales, la ejecución de los trabajos, el avance de la misma y el cumplimiento de los requisitos para ser recibir una vivienda social); con lo cual se evidencian el abandono de tareas por parte del organismo. 
El $\mathrm{IVBA}^{4}$ en sus orígenes estaba dividido en las direcciones de: Administración, Política Habitacional, Obras e Inmobiliaria y Social (dependientes del Administrador). De ésta última dependía el departamento de Estudios Sociales y Adjudicaciones (hoy departamento de Selección de Aspirantes), este departamento realizaba el proceso de selección para la adjudicación de viviendas atendiendo al público de la provincia para consultas e inscripciones.

El proceso de selección de aspirantes se desarrollaba de la siguiente manera:

Ante la demanda de un determinado municipio de la provincia de Bs. As. por la necesidad de construcción de barrios de viviendas sociales, junto con el departamento de Política Habitacional que llevaba una memoria descriptiva del partido, la demanda y otros datos pertinentes para construir los barrios; se acudía a los municipios, se difundía que iba a haber una inscripción para barrios de viviendas con fecha de inicio y cierre de inscripción por medios de comunicación locales, con los requisitos del IVBA (ser argentino o naturalizado, grupo familiar estable con tope de ingresos) y los requisitos municipales (años de residencia en el lugar); se armaba el expediente y se trabajaba para la inscripción de los adjudicatarios, se registraban en un cuadernillo de datos las características socio ambientales del grupo familiar, datos que se volcaban en una encuesta (modelo) con calidad de declaración jurada que constaba de ítems con distintos puntajes de los elementos valorados (tales como características de hacinamiento, promiscuidad, cocina baño/instalada), dado que la demanda siempre era mayor a la cantidad de viviendas a construir se utilizaba el mencionado sistema de puntajes donde se "clasificaba" a las personas por puntajes (Decreto-Ley 21581/77) para la adjudicación de las viviendas.

Luego del total de personas postuladas se tomaba una muestra y se realizaba una visita domiciliaria con los datos de la declaración jurada a las personas con puntajes más altos para ver si coincidían y se confeccionaba un listado de titulares y suplentes "pre adjudicatarios", que luego se mandaban al municipio que la publicaba y se ponía una fecha para que las personas puedan presentar impugnaciones, si existía alguna impugnación por parte de alguna persona (que denunciaba que otra ya tenía vivienda dando el nombre y apellido de la misma) se verificaba en el registro de la propiedad para constatar que no tuviera bienes a su nombre (y de tenerlos no tenía que superar el

\footnotetext{
${ }^{4}$ Información suministrada por Diana Santilli, Asistente Social compañera del IVBA.
} 
50\% del valor del momento de una vivienda FONAVI, y si lo superaba se le asignaba a otra persona la vivienda, al que seguía en la lista de suplentes), quedando pendiente hasta que se resuelva su situación, y luego se formulaba el listado definitivo, este era el momento más crítico por ser decisivo para una persona en acceder o no a la vivienda.

Más tarde en la época de la descentralización estas tareas las comenzó a realizar el municipio, se perdió la comunicación directa con la gente, solo se asesoraba al municipio para que realizara el proceso de inscripción, se perdió así el vínculo con la persona adjudicataria; solo se recibía el listado de adjudicatarios realizado por el municipio y se mandaba al registro patrimonial inmobiliario del IVBA para su verificación.

Retomando con el proceso de selección de aspirantes una vez terminado el listado de los adjudicatarios de las viviendas, se enviaba al departamento de Catastro, ${ }^{5}$ actualmente denominado Escrituraciones, para la posterior entrega que se realizaba mediante actos públicos donde se les otorgaba la tenencia precaria, excepto en los casos en que había fallecido el titular, se había separado de hecho o divorciado, o estaba privado de su libertad, en cuyos casos la adjudicación quedaba pendiente de entrega hasta resolverse la situación jurídica (se decidía en el momento si dada la situación familiar se le entregaba la llave y quedaba la documentación pendiente hasta resolverse la problemática).

También había casos donde se daba adjudicación en comodato por dos años al titular que no podía pagar la cuota analizando su situación económica y consultando con el Municipio si la persona había perdido el empleo, se podía renovar por seis meses más si la situación continuaba y allí se definía la adjudicación generalmente a favor de la persona.

La entrega de las viviendas se realizaba en su totalidad o por etapas dependiendo de las terminaciones (por avances de obra y financieros). La empresa pedía el final de obra y los inspectores del Departamento de Obras del IVBA viajaban al lugar a supervisarlas.

\footnotetext{
${ }^{5}$ Información suministrada por Mónica Odoguardi, y Marcelo Pilla compañeros del IVBA.
} 
En caso que un barrio se intrusionara (no era masivo), se desalojaba y quedaba a estudio del municipio poder incluir en un próximo plan a las personas desalojadas. Las inscripciones se realizaban en el Municipio con participación activa del IVBA donde se conocía a la persona desde el inicio del proceso hasta el final con la entrega de la vivienda.

La entrega se realizaba en la Municipalidad del partido donde se construyeron las viviendas o en el propio barrio, a través de un acto público, integrado por las autoridades del Municipio (el encargado de acción social), y encargados de Catastro (y posteriormente también autoridades del IVBA -directores, administrador, subadministrador) que viajaban a tal fin (con un día de anterioridad) para entregar a los adjudicatarios una boleta de depósito y hacer efectivo en el Banco Provincia el pago de la primer cuota de la unidad, y luego contra la entrega del comprobante de depósito se le hacía firmar al titular el acta de tenencia precaria, se le entregaba la llave, se supervisaba la vivienda (junto con personal municipal y de la empresa constructora) y se realizaba un acta de verificación para ver si existía alguna falla o faltaba algo, también se probaban los artefactos (cocina, calefón), de ocurrir alguna falla la empresa constructora se hacía cargo de la reparación en un tiempo perentorio anterior a que las personas se muden, ya que tenían un plazo de 30 días para ocupar las viviendas.

Después de los 30 días de la entrega de la vivienda, se hacía una verificación ocupacional, comprobando si las personas habían ocupado efectivamente las viviendas y de no haberlo hecho se las citaba para ver que inconvenientes tuvieron para no ocuparla. Por ejemplo en los pueblos, las personas que trabajaban los campos donde les daban alojamiento, aun sin tener vivienda propia, no la ocupaban porque priorizaban su trabajo, entonces se les pedía que un miembro de la familia ocupe la vivienda o alguien de confianza (que muchas veces se terminaba quedando con las viviendas).

El Departamento Contralor: tenía la potestad de la desadjudicación de las viviendas (decomiso con lo que tenían adentro) por denuncias de delitos, porque no pagaban las cuotas o no ocupaban las viviendas. Si los adjudicatarios dejaban de pagar se los notificaba y se les daba un plan de pagos para que regularicen su situación, también podía ocurrir que vendían ilegalmente las casas y quien continuaba no quería pagar al IVBA porque decía que ya la había comprado, solo a través del IVBA con la escritura 
hipotecaria y la cuota al día se podía transferir a otra persona que continuaría con los pagos.

Al tiempo de la entrega del acta de tenencia precaria se reemplazaba por un "boleto de compra venta" entre el IVBA y el adjudicatario hasta el momento de la escritura con hipoteca (precio provisorio), dado que las viviendas se pagaban a 30 años, recién cuando se finalizaba de pagar se entregaba la escritura sin hipoteca libre de todo gravamen (precio definitivo).

Este procedimiento de entrega se hizo así aproximadamente hasta la década de los `90. Con la descentralización que trasladó tareas del IVBA a los Municipios, la intervención social, a partir de allí pasó a ser específicamente municipal, ya que este era quien realizaba la selección y entregaba el listado de los adjudicatarios (personas, entidades intermedias, sindicatos) al IVBA. Desde ese momento, el IVBA fundamentalmente se dedicó al financiamiento de la obra (realizar los desembolsos de dinero a las empresas/entidades/cooperativas de acuerdo al avance de obra), con el debilitamiento de las áreas sociales y de obras (los prototipos también eran municipales).

Actualmente se entrega la escritura hipotecaria y la llave de la vivienda al entregar el barrio.

Dados los tiempos de obras muchas veces quedaban desactualizados los datos de los adjudicatarios, desde que se realizaba la inscripción hasta que se efectuaba la entrega (por fallecimientos o nacimientos). Así como también el retraso desde que la persona ocupaba la vivienda hasta que comenzaba a pagar y se le entregaba la escritura hipotecaria (haciéndose cargo el IVBA de los costos del barrio); terminándose a veces después de muchos años por regularizar al ocupante y no al adjudicatario inscripto inicialmente.

Existen casos (como CONVIV 9 viviendas) donde personas que quedaban suplentes o empleados públicos armaban una sociedad civil y solicitaban al IVBA ser incluidas en proyectos de autogestión constructiva, similar al ATEPAM de los años `60. En los cuales se incluyó en la construcción al grupo familiar (no solo al jefe de familia), que era evaluado por una Trabajadora Social para ver si era idóneo. Una vez conseguida la tierra (ya sean fiscales, remanentes FONAVI o privadas con posibilidad de compra), se iniciaba la obra y la adjudicación se hacía por mérito de horas trabajadas (que se 
registraba diariamente en la obra en un libro de actas con la firma de los autoconstructores), el maestro mayor de obras los dirigía y los supervisores de obras del IVBA certificaban los avances para los desembolsos. Una vez finalizadas las viviendas se les entregaba el acta de posesión, luego la escritura hipotecaria (hasta que finalicen de pagar las cuotas) y por último la escritura definitiva.

Para el caso de la Erradicación de Villas, en el lugar donde estaba asentada la villa se construía el barrio y se enviaba a las personas a lugares transitorios; era un momento muy difícil el de la retirada de los habitantes generalmente acudían las autoridades policiales y los miembros (encargados de Catastro) del IVBA, ya que muchos no querían abandonar el lugar, una vez retirados los animales, los carros y las pertenencias personales se "tiraba abajo todo" y quedaba solo la tierra y ahí se construía luego el barrio.

En el Departamento de Obras los auditores/ inspectores de obras divididos por municipios de la provincia, dirigían, verificaban y certificaban los avances de obra para los desembolsos de dinero (generalmente se daba un anticipo y luego contra certificaciones se realizaban los siguientes desembolsos). Y posteriormente una vez definido el lugar a construir analizaba el suelo para ver si era apto para la construcción (no inundable), se definía la tierra disponible y la tipología de viviendas.

El departamento de Control de Gestión ${ }^{6}$, registraba una planilla con los datos de la obra desde la publicación de la licitación para la presentación de las empresas, el inicio de la obra, la evolución, el porcentaje de avance financiero y físico de la obra, (finalización de obra con plazo de seis meses para revisión de vicios ocultos y su corrección), hasta la adjudicación. En los inicios había direcciones y subdirecciones con la descentralización aparecieron las direcciones generales.

En 1983 se comienza a ampliar la cantidad de personal del IVBA, que en la actualidad aproximadamente asciende a 654 personas (de los cuales 364 son técnicos, profesionales y autoridades/jerárquicas). En el año 2003, el Poder Ejecutivo de la Provincia de Bs. As, por medio del decreto 1441/2003 aprueba la siguiente estructura orgánica descentralizada de la Administración General del IVBA: 1 Administrador

${ }^{6}$ Información suministrada por Mabel Conrat, Jefa de Liquidación de Órdenes de Pago del Depto. Contable. 
General, 1 Subadministrador, 3 Directores Generales y 21 Jefes de Departamento (ver anexo).

\section{Operatorias de Vivienda de la sub-etapa centralizada (1983 a 1992)}

Se encuentran las siguientes operatorias (algunas si bien se inician en períodos anteriores como las FONAVI y FOPROVI, es aquí cuando se desarrollan y adquieren mayor relevancia):

\section{Operatorias de Vivienda de esta subetapa:}

Operatoria FONAVI: 30.475 viviendas.

Operatoria FOPROVI: 4.514 viviendas.

Operatoria Coparticipación Autogestión: 2.085 viviendas.

Operatoria Pro Casa: 2705 viviendas.

Operatoria Pro Casa-Solidaridad-Vuelta al Pago-Pro Techo-Reconstrucción de Barrios: 424 viviendas

Retomando a Igarzabal (1999) a partir de 1991, con el inicio del Plan Convertibilidad destinado a revertir el proceso inflacionario se provoca la paralización de las obras en ejecución, los retrasos en las obras licitadas y el incumplimiento con el llamado a licitación pública de los últimos emprendimientos comprometidos bajo el régimen centralizado. Ante esta situación la Secretaria de Vivienda y Ordenamiento Ambiental (SVOA) tomó medidas para reconvertir los contratos con las empresas constructoras evitando los largos procesos rescisorios y así concretar su finalización y sobre todo satisfacer las expectativas de los destinatarios.

En esta etapa se da inicio a las Operatorias de vivienda Descentralizadas (que se intensificarán en la próxima etapa), la integración a las mismas se realiza a través de los Municipios y las Entidades Intermedias.

Los Programa Descentralizados tienen como objetivos:

- movilizar los recursos para dar respuestas a las familias que necesitan tierra y vivienda,

- promover la organización social a través de sus entidades representativas, 
- descentralizar hacia los municipios y estos hacia las organizaciones sociales,

- incentivar la actividad local generando puestos de trabajo en cada municipio,

- promover la inserción física y social en la trama urbana,

- desarrollar la solidaridad para aumentar la devolución de cuotas para la reinversión,

- optimizar la utilización de los recursos existentes, reducir los tiempos de ejecución de las obras, y mejorar la calidad del hábitat,

- consolidar la descentralización en las direcciones o Institutos de Tierra y Vivienda municipales autárquicos y el fondo municipal permanente para la vivienda de interés social al que se destina el $35 \%$ de los recursos que gira la provincia a cada municipio (reintegran el 65\% del préstamo),

- asesorar la gestión de organismos municipales específicos.

Los Aspirantes tienen que cumplir las siguientes condiciones:

- conformar un grupo familiar,

- no poseer inmuebles propios u otros bienes equivalentes a una vivienda,

- no haber sido adjudicatarios de lote y/o vivienda financiada por el Estado,

- no tener ingresos familiares suficientes como para acceder a la vivienda con recursos propios,

- residir en la zona,

- en el caso de las asociaciones sin fines de lucro deben poseer personería jurídica y tierras aptas.

Las tierras deben ser:

- provinciales o municipales, de Entidad intermedia o lote individual privado,

- aptas urbanísticamente y no inundables,

- con factibilidad de provisión de servicios,

- con título de propiedad.

La Operatoria Autogestión Constructiva: con vigencia de 1985 a 1992, se caracteriza por:

Objetivo: acudir en ayuda financiera a los Municipios y Entidades sin fines de lucro con fondos para la construcción de conjuntos habitacionales dirigidos a los sectores de bajos recursos económicos y escasa capacidad de ahorro a través del Sistema de Esfuerzo Propio y Ayuda Mutua. Esta operatoria tiene el doble propósito de la 
integración social de un grupo organizado de auto constructores para construir sus propias viviendas por medio de una adecuada metodología de trabajo entre el grupo técnico conductor y el grupo de destinatarios. El IVBA contribuye al programa con el financiamiento de las viviendas, el asesoramiento técnico social y la supervisión de las obras. Los Municipios y Entidades contribuyen con las tierras, la selección de destinatarios, el equipo conductor y la administración de los fondos. Los destinatarios aportan la mano de obra necesaria con su esfuerzo personal y sostenido durante el plazo de la obra.

Financiamiento: del IVBA por medio del Fondo Provincial de Vivienda creado a tal efecto y un monto fijo por unidad de vivienda.

Usuario: seleccionado por el Municipio de la demanda general y las Entidades de sus asociados con características de autoconstructor con necesidad de vivienda.

Proyecto: conjuntos habitacionales de viviendas en planta baja y un dormitorio realizados por el IVBA y/o el Municipio bajo su asesoramiento y supervisión.

Tecnología: sistema constructivo tradicional con materiales convencionales y de fácil ejecución.

Ejecución: Municipalidad o Entidades Intermedias, por el Sistema de Administración de Obras, con el aporte de mano de obra del usuario y supervisión y asesoramiento del IVBA.

Resultado: 285 conjuntos habitacionales de 5037 viviendas (770 viviendas en el conurbano y 4267 viviendas en el interior de la provincia).

Superficie promedio de cada vivienda: $40 \mathrm{~m}^{2}$

La Operatoria Pro Casa: con vigencia de 1987 a 1992, se caracteriza por:

Objetivo: acudir en ayuda financiera a los Municipios de la Provincia de Bs As para la construcción de conjuntos habitacionales dirigidos a los sectores de bajos recursos económicos y escasa capacidad de ahorro como parte del programa de coparticipación, donde el IVBA aporta un financiamiento fijo por unidad de vivienda, el asesoramiento técnico en las distintas etapas y la supervisión de las obras, los Municipios contribuyen con las tierras e infraestructura necesarias, la selección de los destinatarios, el equipo conductor de la obra, la administración de los fondos y la responsabilidad de la ejecución de las obras.

Financiamiento: del IVBA por medio del Fondo Provincial de Vivienda creado a tal efecto y un monto fijo por unidad de vivienda. 
Usuario: seleccionado por el Municipio de la demanda general con la supervisión del IVBA.

Proyecto: conjuntos habitacionales de viviendas en planta baja y un dormitorio realizados por el IVBA y/o el Municipio bajo su asesoramiento y supervisión.

Tecnología: sistema constructivo tradicional con materiales convencionales.

Ejecución: Municipalidad preferentemente por el Sistema de Administración de Obras.

Resultado: 392 conjuntos habitacionales de 7911 viviendas (1028 viviendas en el Conurbano y 6883 viviendas en el interior de la provincia).

Superficie promedio de cada vivienda: $40 \mathrm{~m}^{2}$

\section{Las Operatorias ProCasa/ Solidaridad/ Vuelta al Pago/ Pro Techo/}

Reconstrucción de Barrios: con vigencia de 1987 a 1992, se caracterizan por:

Objetivo: acudir con el aporte financiero a soluciones habitacionales particularizadas dirigidas a distintos sectores marginados de la sociedad con la finalidad de asegurar la reconstrucción, ampliación y/o relocalización, para el arraigo familiar y las fuentes de trabajo, con la adhesión y participación activa de los Municipios y/o las Organizaciones Vecinales promovidas por sus habitantes.

Financiamiento: del IVBA por medio del Fondo Provincial de Vivienda creado a tal efecto y un monto fijo por unidad de vivienda.

Usuario: seleccionado por el Municipio o las Organizaciones Intermedias con la supervisión del IVBA.

Proyecto: viviendas, ampliaciones y terminaciones en planta baja realizados por el Municipio y/o las Organizaciones Intermedias bajo el asesoramiento y supervisión del IVBA.

Tecnología: sistema constructivo tradicional con materiales convencionales.

Ejecución: Municipalidad preferentemente, por el Sistema de Administración de Obras, y/o la autoconstrucción del usuario.

Resultado: 19 conjuntos habitacionales de 892 viviendas (473 viviendas en el Conurbano y 419 viviendas en el interior de la provincia).

Superficie promedio de cada vivienda: $35 \mathrm{~m}^{2}$

La Operatoria Rural: con vigencia de 1986 a 1995, se caracterizan por:

Objetivo: acudir en ayuda a sectores de bajos recursos económicos con soluciones habitacionales para implementar radicaciones en las jurisdicciones cuya actividad 
económica se encuadra dentro de la explotación agropecuaria o agroindustrial para asegurar la radicación de sus pobladores.

Financiamiento: del Ministerio de Obras y Servicios Públicos (MOSP) a través de fondos provenientes de Rentas Generales.

Usuario: seleccionado por el Municipio de la demanda general de la localidad.

Proyecto: conjunto de viviendas individuales realizados por el MOSP. Viviendas, ampliaciones y terminaciones en planta baja realizados por el Municipio y/o las Organizaciones Intermedias bajo el asesoramiento y supervisión del IVBA.

Tecnología: sistema constructivo tradicional con materiales convencionales.

Ejecución: las obras se ejecutan mediante convenios celebrados entre el MOSP y el Municipio por licitaciones públicas y contratos de obra.

Resultado: 202 conjuntos habitacionales de 1965 viviendas.

Superficie promedio de cada vivienda: $35 \mathrm{~m}^{2}$

Esta subetapa puede resumirse en el siguiente cuadro y gráficos que muestran las Operatorias/Programas del IVBA y su cantidad de viviendas y tamaños.

\begin{tabular}{|c|c|c|c|c|c|c|}
\hline Operatoria/Programa del IVBA & & & & & & \\
\hline Etapa 1983 a 1992 & Años Vigenc & Ejecución & Financiamiento & Usuario & Metros $2 x$ Viv & Viviendas \\
\hline FONAVI & 1983-1992 & constr.IVBA $x$ lic pub y co & IVBA-FONAVI & demanda gral y/o asoc.de e & $\begin{array}{r}62 \\
\end{array}$ & 30,475 \\
\hline FOPROVI & 1983-1992 & constr.IVBA $x$ lic pub y co & IVBA-FOPROVI & demanda gral munic.o segú & 52 & 4,514 \\
\hline Autogestión Constructiva & 1985-1992 & const. $x$ muni o $x$ ent.intern & IVBA-FOPROVI & demanda gral munic.o asoc & 40 & 2,985 \\
\hline Procasa & 1987-1992 & construcción x munic. & IVBA-FOPROVI & demanda gral del municipio & 40 & 2,705 \\
\hline ProCasa-Solidaridad-Vuelta al Pago-ProTecho-Reconstri & 1987-1992 & const. $x$ muni o $x$ autocons & IVBA-FOPROVI & demanda gral muni.y/o asoc & 35 & 424 \\
\hline Totales del Período & & & & & 46 & 41,103 \\
\hline
\end{tabular}

Cantidad de viviendas construidas en la subetapa 1983-1992

Operatoria/Programa del IVBA
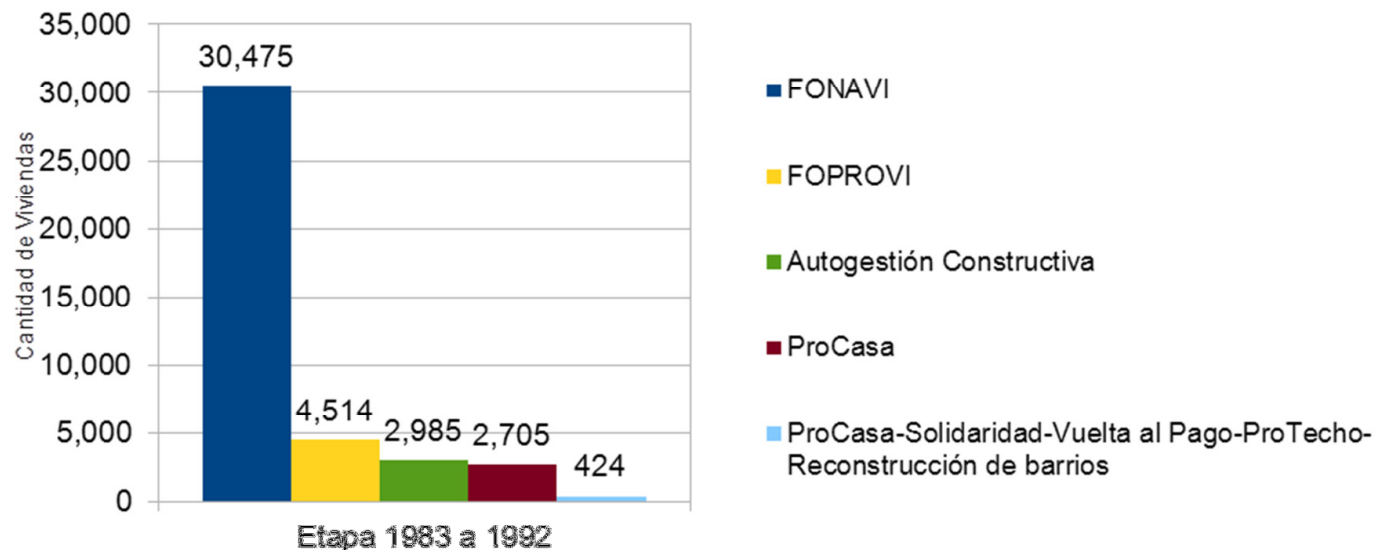
Superficie de viviendas construidas en la subetapa 1983-1992

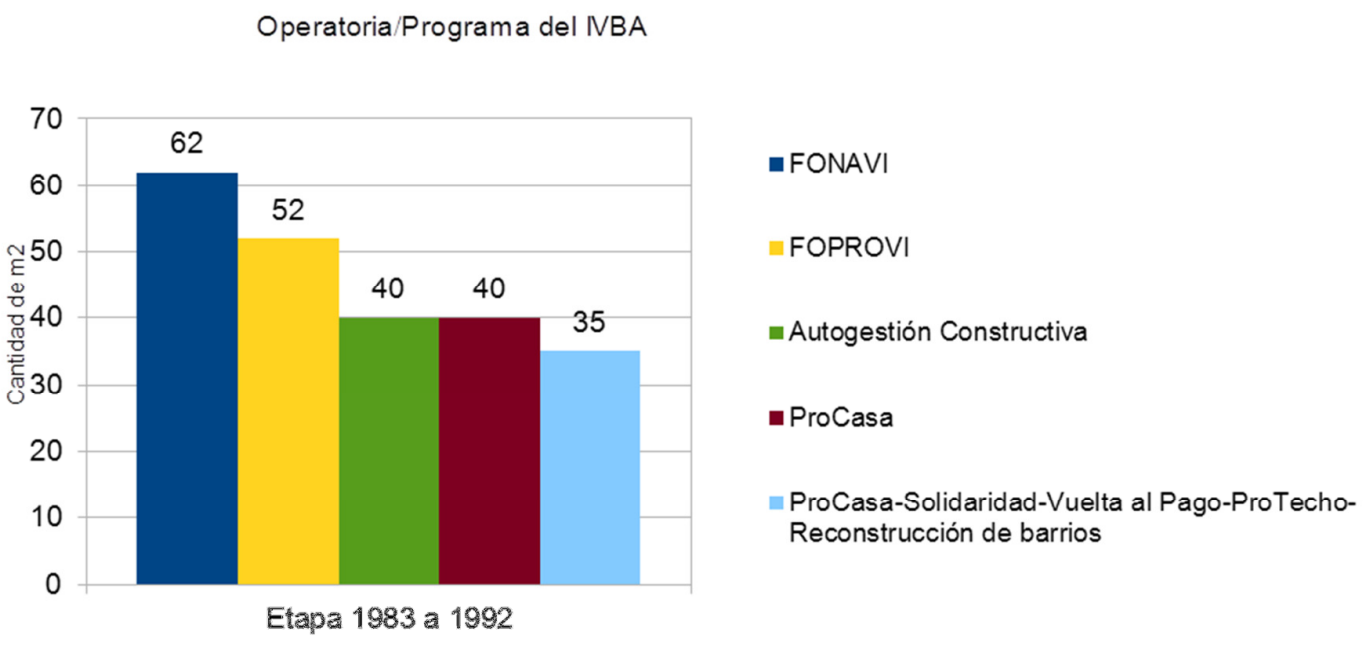

Como conclusión de esta sub-etapa de 1983 a 1992, en el Modelo de Acumulación Aperturista, la Política Habitacional del IVBA a través de la Operatoria FONAVI, produce la construcción de gran cantidad de viviendas en conjuntos habitacionales, acercando a las personas a la concreción del Derecho a la Vivienda y produciendo un avance en relación a los períodos anteriores; sin embargo este avance no incluye el Derecho a la ciudad, dadas las ubicaciones en las periferias de las viviendas, en los conjuntos habitacionales, donde las personas se ven alejadas de concretar sus otros derechos de trabajar, de transportarse, de vivir dentro de la centralidad y las posibilidades que ésta ofrece.

\section{La subetapa descentralizada (1992 a 2003):}

Se caracteriza por la primacía de los organismos financieros internacionales en la definición de la Política Habitacional, siguiendo con las recomendaciones de los Organismos Multilaterales de crédito (FMI, BID y Banco Mundial) la política de vivienda se aparta definitivamente de ser parte del modelo de acumulación y pasa a ser parte del gasto social, por lo que se pretende reducir su peso y se concibe como un complemento de la "estrategia de lucha contra la pobreza" que proponen los organismos.

Así, las políticas sociales son focalizadas en los más pobres y grandes grupos de población quedan sin ningún tipo de cobertura, respondiendo a los mandatos de los 
organismos multinacionales de financiamiento, son dirigidas a la figura del beneficiario, desconocen los derechos sociales y otorgan "beneficios".

En esta etapa se desarrollan los siguientes programas de:

- Regularización de loteos (adecuación de loteos irregulares a los estándares urbanos vigentes),

- Regularización fundiaria (regularización de tenencia de los inmuebles),

- Urbanización de asentamientos irregulares,

- Capacitación y asesoramiento para la vivienda popular,

- Bancos de tierras y materiales,

- Micro créditos para mejoramiento de vivienda.

Según Fernández Wagner (2008) tras la descentralización del FONAVI en 1992, éste adquiere una tendencia favorable a la mercantilización de la vivienda alejándose de la concepción original de vivienda social, ya que sus productos se destinan a sectores con poder de repago como los sectores medios (empleados públicos provinciales y municipales) que son los que pueden afrontar el pago de cuotas para el recupero. Similar situación ocurre con la privatización del Banco Hipotecario. La población en situación de pobreza no es considerada población objetivo como destinataria de estos programas.

Para este autor esta etapa genera transformaciones urbanas producto de un Estado que pasa a ser facilitador del mercado, sobre todo del suelo e inmobiliario, con grandes inversiones en autopistas, shoppings, barrios cerrados y countrys, centros de logística y compras de tierras urbanas y campos. También los negocios generados por la privatización de empresas de servicios públicos (agua, gas, y energía eléctrica) tienen influencia en el deterioro de las condiciones sociales urbanas de la población.

Ampliando con Pintos (2012) que considera que el contexto de la liberalización sostenida del suelo y la especulación de los distintos actores económicos y financieros produce tensiones entre el habitar que ofrece el actor inmobiliario frente a una unidad de paisaje natural; y se muestra la tensión socio espacial sobre el territorio, cuando por parte de los sectores acomodados la producción del espacio tiende a la ciudad exclusiva, el country y la comunidad vallada. Y concluye que el neoliberalismo urbano en su accionar no considera la irreversibilidad en la intervención y manipulación de la 
naturaleza (ante una débil regulación), como por ejemplo, las inundaciones producidas por la intervención sobre la cuenca del río Luján en la provincia de Bs. As; y que son los movimientos ciudadanos donde la comunidad aún sostiene los lazos de integración y solidaridad quienes pueden hacerle frente.

Por otro lado, en los barrios populares, donde su población ya no está inserta en trabajos formales y es dependiente de la "ayuda" del Estado se construyen nuevas identidades ligadas a los territorios que ocupan (y a la desocupación y pobreza). En el barrio, se desarrollan nuevos movimientos sociales que reivindican, entre otros aspectos, la regularización de tierras ocupadas. Una respuesta a estos movimientos es el Programa Arraigo que regulariza asentamientos en tierras fiscales aprovechando la desafectación de tierras de uso ferroviarios debido al cierre de ramales. Otra respuesta es la Ley $\mathrm{N}^{\circ} 24146$ del año 1993, de usucapión rápida para regularizar la ocupación de tierras privadas.

A fines de los años '90, el encarecimiento del habitar urbano, las tarifas elevadas de los servicios, la mercantilización de la salud y educación, sumadas a la distribución regresiva de la riqueza generan un agravamiento de las condiciones de habitación por lo que crecen las invasiones de tierras, las tomas de edificios y casas, la aparición de pequeñas villas en zonas de riesgo ambiental, y la ocupación de lotes individuales; a lo que se le suma la degradación de los conjuntos habitacionales construidos por el Estado en décadas anteriores.

Para Clichevsky (2010) las políticas estatales son insuficientes para dar cuenta de las demandas de la población de bajos ingresos de un espacio donde habitar y las consecuencias son el distinto tipo de informalidad y la toma masiva de tierras debido al papel de los actores, incluidos el mercado inmobiliario, el poder judicial y el mismo Estado que no define políticas claras de actuación para dar solución a esta población. También propone políticas urbanas sobre tierra vacante mediante políticas fiscales como la ampliación de la base y los instrumentos impositivos; la aplicación de una política progresiva de impuestos sobre bienes raíces a fin de desalentar la retención de tierras por parte de propietarios pudientes; vinculadas a otros mecanismos diseñados para frenar la expansión de la tierra vacante y la dinámica de segregación y estratificación social y geográfica. 
En la subetapa descentralizada $(1992$ a 2003$)$ en el IVBA se encuentran las siguientes Operatorias de Vivienda: (las propias de la etapa son las Bonaerenses)

Operatoria FONAVI: 13.555 viviendas.

Operatoria FOPROVI: 70 viviendas.

Operatoria Autogestión Constructiva: 2052 viviendas.

Operatoria ProCasa: 5206 viviendas.

Operatoria ProCasa-Solidaridad-Vuelta al Pago-ProTecho-Reconstrucción de barrios: 468 viviendas.

Operatoria Bonaerense I: Abuelos y Novios (1640 viviendas)

Operatoria Bonaerense II: Solidaridad (506 Conjuntos Habitacionales de 20.929 viviendas)

Operatoria Bonaerense II: Solidaridad Titularización de Hipotecas (5.451 viviendas).

Operatoria Bonaerense II: Solidaridad Plan Arraigo (292 viviendas)

Operatoria Bonaerense II: Autoconstrucción y Ayuda Mutua (597 viviendas)

Operatoria Bonaerense II: Solidaridad Vivienda Básica Asistida (547 viviendas)

Operatoria Bonaerense II: Solidaridad Trabajar (1.799 viviendas)

Operatoria Bonaerense III: Financiamiento Compartido (1.523 viviendas)

Operatoria Bonaerense IV: Emergencia Habitacional (719 viviendas)

Operatoria Bonaerense V: Préstamos Familiares (5.672 viviendas)

El Plan Bonaerense de Tierra y Vivienda vigente desde 1992 hasta 1999, con acciones descentralizadas con la delegación de roles ejecutivos, el IVBA asume la responsabilidad que le compete a fin de satisfacer las necesidades básicas de la población con recursos insuficientes y/o escasa capacidad de ahorro implementando un nuevo cuerpo de programas específicos y potenciando el accionar creativo de los Municipios y Entidades Intermedias para optimizar nuevos fines de gestión, organización y recursos humanos, técnicos y financieros coparticipados. 


\section{Estas acciones son:}

Operatoria Bonaerense I: Abuelos, novios, chicos de la calle y violencia familiar. Operatoria Bonaerense II: Solidaridad y Subprogramas

Vigentes desde 1992 a 1999 y caracterizadas por:

Objetivo: acudir con aportes financieros a municipios y entidades sin fines de lucro en ayuda a sectores específicos de la sociedad y de bajos recursos económicos con soluciones habitacionales, donde el IVBA otorga un monto fijo por unidad de vivienda, asesoramiento técnico en las distintas etapas, mientras que el municipio y las entidades contribuyen con la cesión de los terrenos y la ejecución de la infraestructura de servicios necesaria, la selección de los destinatarios, el equipo conductor del emprendimiento, la administración de los fondos y la responsabilidad de la ejecución de las obras, todo bajo la supervisión del IVBA.

Financiamiento: del IVBA a través del FONAVI y FOPROVI con un monto fijo por solución habitacional.

Usuario: seleccionado por el Municipio de la demanda general de la localidad o entre los asociados de las Entidades bajo la supervisión del IVBA.

Proyecto: conjuntos habitacionales de viviendas en planta baja de uno o dos dormitorios, ampliaciones y terminaciones realizados por el IVBA y/o el Municipio y Entidades, bajo el asesoramiento y supervisión del IVBA.

Tecnología: sistema constructivo tradicional con materiales convencionales y sistemas industriales aprobados.

Ejecución: Municipalidades y entidades preferentemente por el sistema de administración de obras.

- Operatoria Abuelos:

Resultado: 74 conjuntos habitacionales de 518 viviendas.

Superficie promedio de cada vivienda: $40 \mathrm{~m}^{2}$

- Operatoria Novios:

Resultado: 73 conjuntos habitacionales de 1025 viviendas.

Superficie promedio de cada vivienda: $40 \mathrm{~m}^{2}$

- Operatoria Solidaridad:

Resultado: 506 conjuntos habitacionales de 20929 viviendas (3764 viviendas en el conurbano y 17165 viviendas en el interior de la provincia).

Superficie promedio de cada vivienda: $50 \mathrm{~m}^{2}$ 


\section{Subprograma Titularización de Hipotecas Banco Hipotecario SA-Provincias}

Resultado: 4812 viviendas titularizadas (3071 viviendas en el conurbano y 2741 viviendas en el interior de la provincia).

\section{Subprograma Reintegración Urbano Social- Plan Arraigo}

Resultado: 881 viviendas (776 viviendas en el Conurbano y 105 viviendas en el interior de la provincia).

\section{Subprograma Autoconstrucción y Ayuda Mutua}

Resultado: 130 viviendas en el interior de la provincia.

\section{Subprograma Vivienda Básica Asistida}

Resultado: 161 viviendas (151 viviendas en el conurbano y 10 viviendas en el interior de la provincia).

\section{Subprograma Trabajar}

Resultado: 268 viviendas en el interior de la provincia.

Operatoria Bonaerense III: Financiamiento Compartido con vigencia desde 1992 a 1998, se caracteriza por:

Objetivo: instrumentar el otorgamiento de asistencia financiera parcial a Entidades Públicas o Privadas, que por sí o asociadas, promuevan o ejecuten emprendimientos habitacionales debiendo, para actuar en calidad de promotora, acreditar capacidad legal, económica, administrativa y técnica para asumir la responsabilidad de la ejecución del programa.

Financiamiento: del IVBA aportará la asistencia financiera parcial a través de los fondos de su administración entre el 50 y $90 \%$ del valor de la vivienda.

Usuario: propuestos por las Entidades y seleccionados de su demanda.

Proyecto: conjuntos habitacionales de viviendas individuales y colectivas con infraestructura de servicios realizados por las Entidades bajo el asesoramiento y supervisión del IVBA.

Tecnología: sistema constructivo tradicional con materiales convencionales.

Ejecución: empresas constructoras contratadas por la Entidad inspeccionadas por el IVBA.

Resultado: 7 conjuntos habitacionales de 1523 viviendas (824 viviendas en el Conurbano y 699 viviendas en el interior de la provincia).

Superficie promedio de cada vivienda: $55 \mathrm{~m}^{2}$ 
Operatoria Bonaerense IV: Emergencia Habitacional con vigencia de 1992 a 1999, se caracteriza por:

Objetivo: acudir con soluciones habitacionales consistentes en la provisión de viviendas industrializadas o asistencia financiera a municipios que se encuentran en situación de emergencia habitacional declarada por el Gobierno provincial, en la cual el municipio se compromete a la localización de las viviendas y su ejecución o montaje y al censo de los grupos familiares afectados, bajo la supervisión y asesoramiento del IVBA.

Financiamiento: del IVBA a través del FONAVI Y FOPROVI y con un monto fijo por vivienda.

Usuario: seleccionado y adjudicado por el Municipio de acuerdo a las necesidades de la emergencia declarada.

Proyecto: la localización y eventual vivienda realizados por el municipio con la supervisión y colaboración del IVBA.

Tecnología: según la modalidad adoptada son viviendas del sistema constructivo tradicional o viviendas industrializadas con sistemas prefabricados.

Ejecución: delegada en el municipio y según el sistema adoptado por administración o contrato de obra.

Resultado: 12 conjuntos habitacionales de 719 viviendas (120 viviendas en el conurbano y 599 viviendas en el interior de la provincia).

Superficie promedio de cada vivienda: $40 \mathrm{~m}^{2}$

\section{Otras Acciones:}

Operatoria Bonaerense V: Asistencia financiera préstamos (resultado 582 subsidios). Subprograma Mejorar (resultado 5672 créditos personales destinados a la refacción de viviendas y la compra de módulos prefabricados).

Operatoria Bonaerense VI: Infraestructura (resultado 118 obras de infraestructura). Obras de equipamiento comunitario (resultados 53 emprendimientos).

Plan de Regularización Escrituraria (resultado al 30/8/99 un total de 67881 viviendas escrituradas y 16000 en trámite).

Planes Especiales: Convenio de Coparticipación Financiera, Convenio marco para la erradicación de asentamientos irregulares localizados en las zonas afectadas por las Obras de Saneamiento del Río Reconquista y Programa de Coparticipación y Asistencia Técnica. 
Cabe mencionar en el marco de la Operatoria Titularización de Hipotecas del Banco Hipotecario Nacional, la suscripción de un convenio en 1995 entre el Banco Hipotecario SA, el Ministerio de Infraestructura y el IVBA (convalidado por el Decreto Provincial 109/97 y la resolución 1720/96 del IVBA). En este convenio, a través de la asistencia del banco, se intenta incrementar la disponibilidad de viviendas sociales. Se le encomienda a dicho banco la gestión y cobranza de los recuperos (provenientes de la adjudicación en venta de las viviendas construidas por el IVBA) para la recaudación eficiente de los recursos, que finalmente no redundó en tal eficiencia e implicó una pérdida de tareas para el organismo.

En esta etapa se realizaba el siguiente debate en el Encuentro Nacional de Trabajadores de Institutos Provinciales de la Vivienda de 2001:

* La defensa de los recursos genuinos destinados a la construcción de viviendas de interés social:

- En los `90 dada la descentralización (de los proyectos, aspectos técnicos, sociales, legales y administrativos) en los municipios o entidades intermedias, el IVBA pierde su rol como planificador y ejecutor de los planes provinciales de vivienda para dar solamente la asistencia técnica y financiera de las obras junto con la reducción presupuestaria de sus recursos específicos de carácter nacional y provincial;

- Con la creación del Fondo Fiduciario para el desarrollo del Plan de Infraestructura Provincial (Ley 12.511) que absorbe hasta el 50\% de los Fondos FONAVI.; se disminuyen las viviendas terminadas en el período y la paralización de obras por falta de recursos.

- En el período 1995-2001 con un déficit provincial de 1.200 .000 viviendas la cobertura real respecto a las viviendas construidas apenas supera el 5\%.

- El Plan Bonaerense de Tierra y Vivienda de esta etapa en su implementación no establece prioridades de asignación de recursos según el déficit de los distintos partidos, no existe un registro de demanda de cada uno de los municipios con criterios homogéneos que permita la centralización de información y el establecimiento de prioridades, para captar el perfil de la demanda y planificar según estos datos, y quedando así marginada la población que carece de capacidad de pago. 
- El postulado que la descentralización se vincula con la "participación ciudadana" no se verifica, dada la escasa convocatoria de la población destinataria de los programas, para que participen en la búsqueda de soluciones,

- Estos programas son usados para conseguir el apoyo popular y la búsqueda de una mayor cobertura lleva a la pérdida de la calidad, y las prioridades en vez de surgir del déficit pueden surgir por tendencias electoralistas,

- Se observan contradicciones entre la formulación y la implementación de la política, en la selección de los adjudicatarios, ya que quedan en situación de privilegio quienes tienen capacidad de pago,

- Como positivo se:

- inicia una gestión de cobranzas para el recupero (al que nunca se había dado importancia y que es uno de los recursos junto con el FOPROVI Y FONAVI).

- reemplaza la construcción de grandes complejos habitacionales que ocasionaron problemas a sus habitantes.

En el marco del Taller de Capacitación AVE (Asociación de Vivienda Económica), CEVE (Centro Experimental de la Vivienda Económica) y SEHAS (Servicio Habitacional y de Acción Social A.V.E.) en el año 2003 donde participaron las distintas áreas del IVBA (la Administración General, Unidad Ejecutora Programa Mejoramiento de Barrios -PROMEBA-, Dirección General de Administración -Dirección de Asistencia Administrativa y Dirección Económica Financiera-, Delegación de Personal, Dirección General de Obras -Dirección de Estudios y Proyectos y Dirección de Ejecución-, Dirección General de Inmobiliario y Social -Dirección de Inmobiliaria y Dirección Social-, Dirección de Política Habitacional -Departamento de Control de Gestión, Departamento de Programación-, Programa Vivienda Rural); ya aparecían los siguientes temas de debate:

- Presupuesto:

El presupuesto hacía dos años (desde 2001) que no se gastaba por razones políticas, además de ser necesario conocer el déficit por sector económico y los recursos asignados por programa; 
- La planificación y los programas:

Los programas que se implementan por lo general no consideran la problemática del hábitat (no solo la construcción de viviendas), es necesario analizar las prioridades de modo de poder abarcar el sector más necesitado y simultáneamente ir terminando las obras ya iniciadas.

- La demanda y el sector de la población destinada:

El análisis de la estructura de la demanda hace necesario considerar qué lugar ocupa en el IVBA dicha demanda, dado que al no tener en cuenta la misma, no se puede analizar la eficacia de lo programado. Por lo tanto es necesario establecer una relación entre la demanda y las programaciones que se planifiquen como respuesta a esa realidad, las dos alternativas del momento en el abordaje de los programas eran ejecutarlos sin un análisis crítico previo u organizar la demanda con la gente de la comunidad.

- Los aspectos generales de la planificación del IVBA y sentido del mismo:

El IVBA parece solo un ente financiero, donde la descentralización tiene sentido para dar posibilidad a la ejecución dinámica, pero es indispensable que desde el IVBA se discuta el déficit de la Provincia para adecuar la planificación, aplicando un esquema de planificación participativa y estratégica para replantear los programas vigentes y los futuros.

\section{Las propuestas y modelos de Políticas Habitacionales surgidos del taller fueron} los siguientes:

1. Voluntad y decisión de plantear una Política Habitacional Social en el marco de una Planificación Progresiva que integre los temas de Trabajo, Desarrollo Social, Medio Ambiente, Salud, Educación, etc.

2. Modelo de Gestión interactoral y democrático, en el marco del Desarrollo Local, convocando a todas las fuerzas sociales capaces de contribuir: Estado, sociedad civil, sector productivo y especialmente a la población para que participe en forma activa y organizada.

3. Vivienda como derecho constitucional, entendida como acceso a la propiedad o tenencia de la tierra, servicios urbanos básicos y vivienda. 
4. Estrategias para el mejoramiento habitacional y la vivienda nueva a partir de un diagnóstico adecuado del déficit habitacional por segmentos socio económicos e imponiéndose un plazo para solucionarlo.

5. Recupero de fondos FONAVI y una reforma tributaria, que brinde los recursos adicionales necesarios, priorizando la aplicación de fondos públicos para la población que no puede acceder por sus propios medios a la obtención del derecho.

6. Sistema Productivo Ampliado: considerando la participación de medianas, pequeñas y microempresas, la autoconstrucción, la ayuda mutua, el trabajo subsidiado por el Estado, los medios de producción cooperativos, solidarios y cogestionados.

7. Pasar progresivamente de una acción de operatorias convencionales de viviendas llave en mano, que responden más a la oferta de grandes empresas, a una Política de Vivienda Social, que requiere:

1) Conocer las experiencias exitosas realizadas en el país y en el exterior para tenerlas en cuenta.

2) Realizar una acción conjunta de gobierno comprometido en horizontal: Vivienda, Infraestructura, Desarrollo Social, Economía, Trabajo, Ciencia y Tecnología, entre otros; y en vertical a los Gobiernos Nacional, Provinciales y Municipales.

3) Responder a las demandas de las necesidades reales de la población.

4) Crear capacidad organizativa a nivel municipal, de ONG's, de organizaciones de base, para ejecutar a mayor escala, apoyado con un programa de asesoramiento y capacitación nacional.

5) Formular y poner en marcha nuevas líneas y operatorias con continuidad.

6) Asignarles recursos crecientes y continuos a estas operatorias

7) Instaurar instancias de monitoreo, evaluación y control estatal de las organizaciones de la sociedad.

Dicho debate posibilitó llegar a las siguientes conclusiones (de ese momento y también aplicables a la actualidad):

- Es importante recuperar niveles de integración y coordinación entre las áreas, involucrar en un análisis conjunto a los directivos para que participen y aumente su compromiso político y decisorio, incorporando la concepción participativa de modo de dar respuestas más apropiadas a la realidad. 
- Realizar propuestas concretas en el corto plazo, como parte de un proceso gradual, en el que se puedan alcanzar resultados, evaluar y reprogramar el abordaje de la demanda y las respuestas a la misma.

Esta subetapa puede resumirse en el siguiente cuadro y gráficos que muestran las Operatorias/Programas del IVBA y su cantidad de viviendas y tamaños de las mismas.

\begin{tabular}{|c|c|c|c|c|c|c|}
\hline \multirow{2}{*}{$\begin{array}{l}\text { Operatoria/Programa del IVBA } \\
\text { Etapa } 1992 \text { a } 2003\end{array}$} & \multirow[b]{2}{*}{ Años Vigenc } & \multirow[b]{2}{*}{ Ejecución } & \multirow[b]{2}{*}{ Financiamiento } & \multirow[b]{2}{*}{ Usuario } & \multirow[b]{2}{*}{ Metros $2 \times$ Viv } & \multirow[b]{2}{*}{ Viviendas } \\
\hline & & & & & & \\
\hline FOPROVI & $1992-1996$ & constr.IVBA $\times$ lic pub y co & IVBA-FOPROVI & demanda gral munic. o segú & 52 & 70 \\
\hline Autogestión Constructiva & 1992-1999 & const. $x$ muni $0 x$ ent.intern & IVBA-FOPROVI & demanda gral munic.o asoc & 40 & 2,052 \\
\hline ProCasa-Solidaridad-Vuelta al Pago-ProTecho-Reconstr & 1992-1999 & const. $x$ muni o $x$ autocons & IVBA-FOPROVI & demanda gral muni.y/o asoc & 35 & 468 \\
\hline Bonaerense l: Abuelos-Novios & 1992-1999 & const. $x$ munic o $x$ ent.inte & IVBA-FONAVI-FOP & demanda gral muni.y/o asod & 40 & 1,543 \\
\hline Bonaerense II: Solidaridad y sus subprogramas & 1992-1999 & const. $x$ munic o $x$ ent.inte & IVBA-FONAVI-FOP & demanda gral muni.y/o asoc & 50 & 22,369 \\
\hline Totales del Período & & & & & 46 & 47,505 \\
\hline
\end{tabular}

Cantidad de viviendas construidas en la subetapa 1992-2003

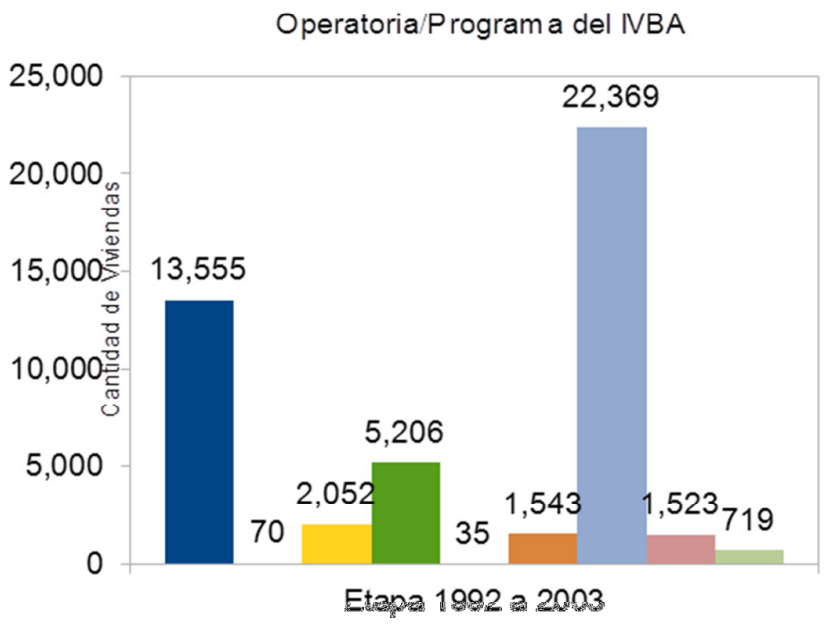

-FONAVI

-FOPROVI

Autogestión Constructiva

- ProCasa

- ProCasa-Solidaridad-Vuelta al Pago-ProTecho-Reconstrucción de

- barrios

n Bonaerense II: Solidaridad y sus subprogramas

口nonaerense III: Financiamiento comprentido 
Superficie de viviendas construidas en la subetapa 1992-2003

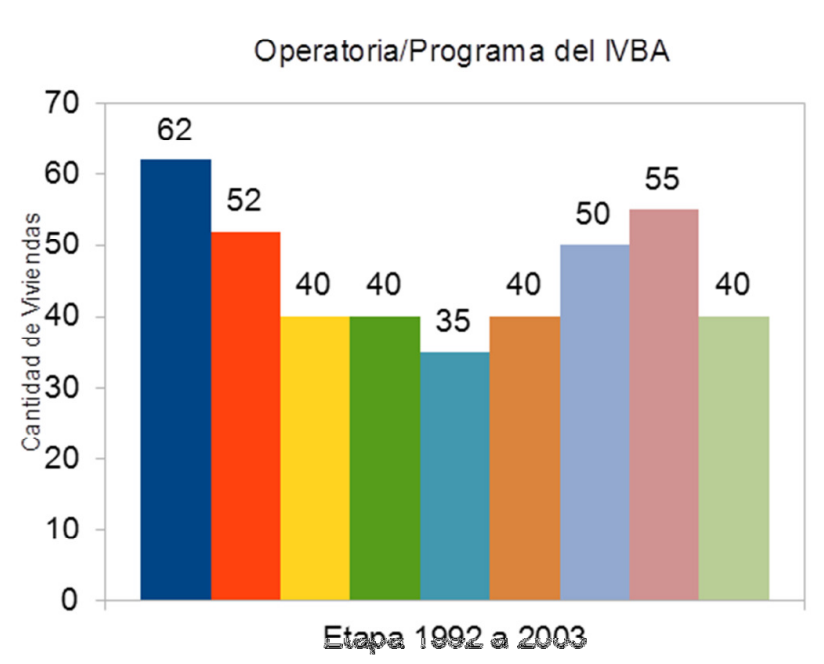

-FONAVI

FOPROVI

Autogestión Constructiva

-ProCasa

— ProCasa-Solidaridad-Vuelta al Pago-ProTecho-Reconstrucción de

borrios

Bonaerense II: Solidaridad y sus subprogramas

Bonaerense III: Financiamiento Compardidb

Como conclusión de esta sub-etapa de 1992 a 2003, en el total de viviendas producido incide la Operatoria del FONAVI correspondiente a la sub-etapa centralizada anterior, tomando en cuenta exclusivamente lo correspondiente a esta sub-etapa en coincidencia con el Modelo de Acumulación Aperturista y la Política Habitacional neoliberal descentralizada y focalizada del momento, durante diez años el IVBA reduce la producción de viviendas con respecto a la etapa anterior del mismo período, la Operatoria con mayor incidencia es el Bonaerense II de Solidaridad y sus subprogramas, con lo cual se da un descenso en la efectivización del derecho a la vivienda-ciudad, desde la cantidad de soluciones habitacionales y también desde el tamaño de las viviendas que con respecto al período anterior es reducido de un promedio de 70 metros a 50 metros, y con eso la calidad de vida de sus habitantes. 


\section{Capítulo VI:}

\section{EI IVBA y la Política Habitacional en la Transición al Modelo Productivo}

(2003-2009)

\section{IV.1. La Política Habitacional en la Provincia de Buenos Aires en el Período 2003- 2009}

\section{Contextualización del período:}

Esta etapa merece una mención especial, porque si bien forma parte del período de economía aperturista se diferencia notablemente de las etapas anteriores, donde el gran decisor era el mercado y ahora lo es el Estado con su intervención, tanto en lo económico como social.

En 2003, el Estado comienza la implementación de políticas de tipo neokeynesianas. La perspectiva dominante, plantea abandonar las políticas aperturistas y consolidar un modelo productivo. En el campo de la política social se plantea la idea de la inclusión social rompiendo con la política social basada en una lógica de focalización para tender a la aplicación de políticas universales de recuperación y conquista de derechos sociales.

La transición a un modelo económico basado en el impulso del mercado interno, desde 2003 a 2009, avanza hacia el paradigma keynesiano, entre otras medidas económicas, por la intervención del Estado para reactivar la economía a través de la obra pública, la nacionalización de Aerolíneas Argentinas, Yacimientos Petrolíferos Fiscales (YPF), Correo Argentino y Astillero Río Santiago, y la creación de ENARSA y Agua y Saneamientos Argentinos. La reactivación económica a través de la construcción y la inclusión social a partir del mejoramiento habitacional tienen en la construcción de viviendas una posibilidad de articularse. La Política Habitacional implementa los Planes Federales de Construcción masiva de Vivienda e Infraestructura, en consonancia con un interés creciente por lo social a través de políticas que intentan ser más abarcadoras y universales como la "Jubilación de Amas de Casa” y la Asignación Universal por Hijo, entre otras. 
Según el autor Fernández Reddel (2010), a partir de 2003 con los gobiernos de Néstor Kirchner y Cristina Fernández se inicia un modelo Productivo guiado por principios neokeynesianos como la intervención del Estado en los aspectos económicos y sociales, con un crecimiento económico que intenta la inclusión social y la distribución equitativa del ingreso. El sector de la construcción a través de la obra pública es el que más empleo crea, por ser de mano de obra intensiva incorpora con un oficio a quienes no lo poseen, al igual que incluye nuevas empresas, grandes, pequeñas y medianas y, también cooperativas de trabajo. Este modelo se centra en dos ejes: el social y el productivo. La inversión social es destinada a vivienda social, servicios básicos, escuelas, hospitales, mejoramiento de barrios y equipamiento urbano. La inversión productiva es destinada a la red caminera, autovías, energía, control de inundaciones, represas y otras destinadas a fortalecer el crecimiento económico.

Para Carballeda (2006) desde el 2003 comienza un modelo de intervención social de tipo neoestadocéntrico; se produce un cambio en las políticas públicas con acciones más equitativas que buscan una mayor redistribución de las riquezas, y el Estado recupera el papel de asignador de recursos que había ocupado el mercado. Por lo tanto se recupera a la política como el espacio de debate sobre las pujas distributivas y los sentidos de las políticas públicas volviendo a valorar a las instituciones, donde los planes y programas sociales son herramientas de transformación de la realidad económica y social.

\section{Descripción de la Política Habitacional del Período:}

Fernández Wagner (2008), se refiere al 2003 como el comienzo de una incipiente reactivación económica (posterior a la devaluación de la moneda), se reinaugura un ciclo donde el Estado interviene en la economía, se acaba el ciclo neoliberal ortodoxo y los monitoreos externos del FMI, obteniendo así el país mayor independencia y las alineaciones internacionales se centran en los países latinoamericanos con un sentido estratégico común.

A fines de 2007, tras cinco años de crecimiento económico, se atraviesa un proceso de transformación territorial relacionada con la reactivación productiva; la reindustrialización da nueva vida a algunas de las antiguas regiones industriales, como es el caso de la Región Metropolitana de Bs.As. con la reactivación de la zona sur (Avellaneda, Lanús, Quilmes), noroeste (San Martín, Tres de Febrero), y norte (eje Panamericana hasta Campana). 
Por otra parte, el escenario internacional de aumento de la demanda de alimentos y la conveniencia cambiaria generan un boom agropecuario que afecta el rol de las ciudades pequeñas y medianas, desplazándose su logística y concentrándose en los puertos (La Plata, Dock Sud y Ciudad Autónoma de Bs.As.) con agregado de conocimiento, tecnología y capital. También toman auge los procesos asociados a la industria del turismo (teatro, música y artes), los servicios de gastronomía y hotelería.

En las villas históricas (en muy pocos casos en villas recientes) se implementa el Plan Federal de Construcción de Viviendas, Subprograma Federal de Urbanización de Villas y Asentamientos Precarios, que da respuesta en algunos casos a villas generadas a partir del plan de erradicación de villas de Capital Federal (como el caso de la Villa Los Álamos, antiguo Núcleo Habitacional Transitorio - NHT).

Fernández Wagner (2008) dice que la bonanza de los sectores medios y altos provoca la demanda de barrios residenciales exclusivos, configurando una ciudad de eterno suburbio que solo permite la conectividad por el uso de las autopistas y el automóvil.

Como contracara, no se produce suelo urbano nuevo para sectores medios y medios bajos. En contraste con otros campos de la política económica y social, las condiciones de acceso a la ciudad empeoran.

La situación generada a partir de los '70 con la desaparición de formas de producción de suelo urbano nuevo para los sectores de ingresos medios-bajos y para los más vulnerables provoca que se extienda en forma generalizada el acceso al suelo en el mercado irregular y/o ilegal.

Por lo tanto, las formas de acceso al suelo nuevo se resuelven por los extremos: a través del barrio cerrado o la ocupación de suelo vacante y luego la lucha por su regularización, siendo muy reducidos los grupos de sectores medios que acceden al suelo por el mercado formal; mantienen su patrimonio familiar heredado de generaciones anteriores o sufren en el mercado de alquileres.

Así mismo, la situación de los más pobres no mejora en el acceso a la ciudad debido a la falta de políticas más estructurales sobre las formas de propiedad, sus derechos y obligaciones, y sobre el desempeño de los mercados. 
Rodulfo (2006) define a la Política Habitacional de este período (a los Planes Federales de vivienda) como Centralizada a nivel de recursos y descentralizada a nivel de localizaciones y "beneficiarios".

El Programa Federal de construcción de viviendas, invierte y construye masivamente, diseñado y ejecutado desde el gobierno nacional tiene como efecto positivo el impulso constructor con alcance cuantitativo; financia dotaciones de servicios de infraestructura y equipamientos sociales, la expansión de las redes de agua y cloacas, y las mejoras en el espacio público, lo cual consolida áreas urbanas que permanecían en la irregularidad, aunque sin política de suelos y acorde con la planificación urbana. Y tiene como efecto negativo, el aumento de la especulación privada en la ubicación de los barrios en detrimento de la decisión de los gobiernos locales.

En la provincia, con fondos de la política descentralizada (FONAVI) y para atender la demanda de sectores no incluidos en el Programa Federal, se implementan diferentes programas:

- El Programa Compartir - Nuestra Casa con financiamiento compartido entre el Instituto de la Vivienda y los Municipios.

- El Programa de Mejoramiento de viviendas y hábitat. Asimismo, orientado a otro sector importante a atender como es el de viviendas existentes recuperables, tanto de conjuntos habitacionales como de viviendas en lotes individuales que requieren un menor costo de inversión por unidad habitacional.

- El Programa Solidaridad que implica la construcción a través de empresas constructoras de viviendas "llave en mano" a demanda de los Municipios o de Entidades intermedias destinado a población trabajadora con capacidad de pago.

Sin embargo, el último quintil de ingresos de la sociedad no es atendido por la política provincial que emerge del Instituto de la Vivienda.

Para Fernández Wagner (2008) en este período de transición, la lucha por el Derecho a la Ciudad es una característica de la realidad social y urbana actual, donde se lucha por el acceso a la Vivienda, a la tierra, a la centralidad, a residir cerca de los lugares de trabajo, a un transporte seguro y accesible, y quienes luchan son los pobladores, las organizaciones, asociaciones profesionales y algunos organismos internacionales. 
El rol de la política en la configuración de una sociedad y una ciudad más justa tiene que ver con la revalorización de la planificación y los instrumentos jurídicos que impidan que sea el mercado quien domine los procesos de urbanización.

Para Reese (2012), el debate sobre un lugar digno donde vivir se centra en la tierra; el cual se invisibiliza dados los intereses dominantes de la propiedad privada. La especulación del mercado inmobiliario explica la paradoja del aumento de inaccesibilidad a la vivienda en un marco de mejora económica producida en los últimos años. Conjuntamente con la construcción de soluciones habitacionales masivas, mejoras sociales, de ingresos y capacidad adquisitiva de las familias continúa y se agrava el conflicto por la tierra porque es el mercado inmobiliario que impone precios inalcanzables a los lotes debido a la especulación (tasa de valorización). Reese fue uno de los impulsores de la nueva Ley 14449/13 de Hábitat Popular (de acceso justo al suelo) que plantea tres principios básicos: la función social de la propiedad, el derecho a la ciudad y la gestión democrática de la ciudad. Es importante destacar que esta ley es complementaria al Decreto-Ley 8912 de 1977 y propone una serie de nuevos instrumentos tanto para la captación de plusvalías como para la generación de suelo urbano y la participación de la población y sus organizaciones en la gestión urbana. En su articulado, esta ley prevé una serie de instrumentos para mitigar la falta de oferta de tierra para loteo popular, como la reimposición de la cesión de tierras a los grandes proyectos urbanos (countrys, hipermercados y clubes de campo).

\section{VI.2-Gestión del IVBA en el Modelo Aperturista en la Transición al Modelo Productivo (2003-2009)}

Durante este período, el IVBA ha tenido un importante desarrollo ligado en gran medida a una fuerte presencia de las operatorias federales. Lo que le dio a la política habitacional un fuerte signo centralizador. A pesar de esta tendencia también gestionó una variedad de operatorias de origen provincial.

\section{Operatorias de Vivienda federales}

Operatoria Solidaridad -Terminación (10579 viviendas)

Operatoria Federal (6495 viviendas)

Operatoria Federal con Municipios (13634 viviendas) 
Operatoria Compartir Nuestra Casa (773 viviendas)

Operatoria Mejor Vivir (72 viviendas)

Operatoria Emergencia Habitacional (704 viviendas)

Operatoria Villas (3622 viviendas)

Los Programas Federales de Vivienda surgen con el objetivo de resolver problemas de crecimiento, empleo, inclusión social y equidad; para disminuir el déficit habitacional existente en el país, facilitando el acceso a una vivienda digna y a diferentes soluciones de infraestructura básica para lograr una mejor calidad de vida para los argentinos ${ }^{7}$. Se produce a través de ellos, una articulación de políticas sociales (de vivienda, de empleo, y salud, entre otras), entre el Ministerio de Planificación Federal, Inversión Pública y Servicios de la Nación, el Ministerio de Desarrollo Social, el Ministerio de Salud y Ambiente, y el Ministerio de Trabajo, Empleo y Seguridad Social, IVBA y Municipios. Con una lógica de reinserción social y laboral se construyen viviendas con mano de obra de pobladores desocupados organizados en cooperativas de trabajo (como por ejemplo el Subprograma de Integración Comunitaria).

Los Planes Federales de Vivienda tienen como Objetivos:

- Desarrollar un esfuerzo mancomunado con el sector inmobiliario y la industria de la construcción, movilizando su capacidad de generar riqueza.

- Implementar políticas de reactivación económica y generación de empleos.

- Promover la construcción de una vivienda evolutiva como primera respuesta a las necesidades del sector con menor poder adquisitivo.

- Incorporar suelo urbano disponible estimulando legítimo interés de los propietarios por realizar un valor que no encuentra demanda en el mercado.

- Incrementar la densidad de habitación en las zonas residenciales consolidadas y contribuir al mejoramiento del tejido urbano en las áreas de expansión.

Organismos intervinientes: Ministerio de Planificación Federal, Inversión Pública y Servicios de la Nación; IVBA; Municipios de la Provincia de Buenos Aires.

Usuarios: los sectores sociales de bajos recursos carentes de vivienda propia, y que no cuenten con recursos económicos para resolver por sí mismos esta problemática. Para ello resulta prioritario constituir un grupo familiar o consensual, tener capacidad de

\footnotetext{
${ }^{7}$ Según información extraída de la página Web del IVBA.
} 
pago y no haber sido ninguno de los miembros del grupo conviviente destinatarios de viviendas financiadas por el Estado, excepto quienes acrediten haber constituido un nuevo grupo familiar.

Modalidad de Ejecución: la construcción de las viviendas se realiza mediante Licitación Pública en los términos de la Ley $\mathrm{N}^{\circ}$ 6.021, pudiendo participar todas las empresas inscriptas en el Registro de Licitadores del Ministerio de Infraestructura,

Modalidad Tierra Fiscal: la tierra para la construcción de la vivienda es de propiedad de los Municipios, la Provincia o la Nación.

Modalidad Tierra y Proyecto Urbano: las empresas constructoras aportan terrenos de su propiedad, pudiendo asociarse con un propietario de suelo o poseer un compromiso irrevocable de venta que les permita comprometer el futuro de los predios donde se construirán las viviendas.

A través de esta nueva modalidad se propone:

- Garantizar la realización del Programa Federal de Construcción de Viviendas en la provincia de Buenos Aires.

- Seleccionar las mejores localizaciones posibles, promoviendo la integración de sus habitantes a los beneficios de la ciudad.

- Optimizar el uso del suelo urbano ya fraccionado, completando la ciudad y elevando zonas de valor inmobiliario deprimido.

- Mejorar la calidad urbana de los proyectos de vivienda social.

Financiamiento: la ejecución de las viviendas se realiza con aportes financieros aportados mayoritariamente por el Estado Nacional y una contraparte provincial.

Reintegro: los destinatarios reintegran el valor de las viviendas hasta en 600 cuotas mensuales iguales y consecutivas con una tasa subsidiada efectiva anual del cero por ciento y el recupero está a cargo del Instituto de Vivienda Provincial, pudiendo celebrar convenios con los respectivos municipios en donde se desarrollan las obras. El pago de las cuotas por parte de los adjudicatarios es obligatorio. Los fondos generados con el recupero de las cuotas formarán parte de una partida con asignación específica en el IVBA para el financiamiento de otras operatorias.

Proyecto y documentación técnica: el IVBA desarrolla y pone a disposición de los equipos técnicos municipales diversos prototipos de vivienda, asistiéndolos técnicamente en otros casos para su desarrollo y en la etapa de formulación de los respectivos proyectos urbanos. 
El plan se implementó a partir de los siguientes subprogramas:

- Construcción de Viviendas con Municipios

- Urbanización de Villas y Asentamientos Precarios

- Mejoramiento de Viviendas "Mejor Vivir"

- Integración Socio Comunitaria (Ex Emergencia Habitacional)

- Reactivación (Municipios - Entidades)

El Subprograma Federal Construcción de Viviendas con Municipios está destinado a la ejecución de obras de vivienda y su infraestructura realizadas a través de los respectivos municipios de manera de resolver el déficit habitacional, la inclusión social y la equidad. Se caracteriza por los objetivos y organismos intervinientes antes mencionados.

Usuario: grupo familiar o consensual, con capacidad de pago de acuerdo a la operatoria y no haber sido ninguno de los miembros del grupo conviviente destinatarios de viviendas financiadas por el Estado, excepto quienes acrediten haber constituido un nuevo grupo familiar.

Modalidad de ejecución: a través de empresas constructoras contratadas por licitación pública. Los terrenos son aportados por los municipios.

Reintegro: el recupero está a cargo del Instituto de Vivienda Provincial, pudiendo celebrar convenios de cogestión del recupero con los municipios donde se desarrollan las obras. Los destinatarios pueden reintegrar el valor de las viviendas hasta en 600 cuotas mensuales iguales y consecutivas, con una tasa subsidiada efectiva anual del cero por ciento. La cuota surge de la inversión realizada, descontando la correspondiente a infraestructura.

Proyecto y documentación técnica: elaborado por los municipios con asistencia técnica del Instituto de la Vivienda, cuando estos así lo requieran.

El Subprograma Federal Urbanización de Villas y Asentamientos Precarios busca disminuir el déficit habitacional y urbano de población de villas y asentamientos precarios, a través de la gestión de proyectos de urbanización integral que pueden incluir la construcción de unidades de vivienda nueva, módulos de mejoramiento, dotación de infraestructura y saneamiento ambiental.

La decisión de radicación de la población no sólo tiene como criterio el reconocimiento de derechos sobre la tierra ocupada, sino también, la optimización en el 
uso del suelo urbano. Adicionalmente el Programa despliega acciones de reactivación económica y generación de empleo.

Objetivos:

- Mejorar la calidad de vida de la población asentada en villas y asentamientos precarios con carencia de infraestructura básica de servicios, problemas ambientales y de regularización dominial.

- Consolidar a la población en el sitio que habita, regularizando el dominio de la tierra a favor de sus ocupantes efectivos, proveyendo infraestructura básica de servicios, consolidando los espacios públicos, mitigando los problemas ambientales e incorporando infraestructura privada de saneamiento básico.

- Relocalizar aquellas familias que se encuentran ubicadas en sectores urbanos de alto riesgo ambiental.

Organismos intervinientes: Ministerio de Planificación Federal, Inversión Pública y Servicios de la Nación; IVBA; Municipios de la Provincia de Buenos Aires.

Usuario: los habitantes de villas y asentamientos precarios del área metropolitana bonaerense y los grandes aglomerados urbanos del interior como Bahía Blanca y Mar del Plata.

Modalidad de ejecución: el Programa puede ser ejecutado por el IVBA o por los Municipios. La modalidad de contratación de las obras podrá ser a través de Licitación Pública.

Financiamiento: la ejecución de las obras se realiza con aportes financieros del Estado Nacional al organismo ejecutor, en calidad de no reintegrables.

Reintegro: el recupero está a cargo del Instituto de Vivienda Provincial, pudiendo celebrar convenios de cogestión del recupero con los municipios donde se desarrollan las obras.

Los destinatarios pueden reintegrar el valor de las viviendas hasta en 600 cuotas mensuales iguales y consecutivas, con una tasa subsidiada efectiva anual del cero por ciento. La cuota surge de la inversión realizada, descontando la correspondiente a infraestructura.

El gobierno provincial aplica una quita del 30 por ciento del valor a reintegrar, en función del sector social al que atiende el Programa. Si la familia hubiera sido relocalizada, dando lugar al avance de las obras, se adicionará un 15 por ciento de quita en concepto de indemnización. El pago de las cuotas por parte de los adjudicatarios es obligatorio. 
Los fondos generados con el recupero de las cuotas formarán parte de una partida con asignación específica en el IVBA para el financiamiento de otras operatorias. Proyecto y documentación técnica: los proyectos y su documentación técnica son elaborados por los municipios con asistencia técnica del Instituto de la Vivienda, cuando estos así lo requieran.

Organización: el punto de partida de la gestión y el modo de relación con los vecinos constituye un punto esencial en el proceso. La promoción de formas organizativas y de concertación favorece la apropiación y el mejoramiento del proyecto urbano por parte de los destinatarios, permitiendo intervenir en el diseño de las viviendas y adaptarlas a las necesidades reales. También favorece la toma de conciencia sobre los derechos ciudadanos que los amparan y de las obligaciones asumidas.

El Subprograma Federal Mejoramiento de Viviendas "Mejor Vivir" está destinado a la terminación, ampliación - refacción de la vivienda de grupos familiares que necesiten que su actual vivienda sea completada y/o mejorada, cuando a partir de su propio esfuerzo hayan iniciado la construcción de su vivienda única y no tengan acceso a las formas convencionales de crédito; así garantiza el mayor impacto social con la menor inversión, y es reactivador de las economías locales, generador de empleo y permite a los destinatarios el control sobre la obra y sus ejecutores.

Objetivo: mejorar las condiciones de vida de los ciudadanos que habitan viviendas permanentes en lote propio, construidas con materiales no precarios, en condiciones de hacinamiento, condición deficitaria de la vivienda y/o con deficiencias sanitarias mediante la construcción de un núcleo sanitario y/o cuartos adicionales.

Para esto se desarrolla la creación de un proceso social, productivo y participativo que permite la reinserción laboral y la organización de sectores más necesitadas de la población.

Organismos intervinientes: Ministerio de Planificación Federal, Inversión Pública y Servicios de la Nación; IVBA; Municipios de la Provincia de Buenos Aires.

Usuario: el programa se orienta a realizar intervenciones en aquellas viviendas que cumplan con las siguientes características:

- se encuentren en lotes que acrediten título de propiedad o cuyo título tramite en alguna operatoria de regularización dominial.

- estén habitadas en condiciones de hacinamiento crítico. 
- cuenten al menos con un cuarto construido con materiales no precarios, incluyendo como tal a la vivienda industrializada de madera en buenas condiciones de conservación.

- se encuentren en lotes en los que exista disponibilidad de espacios libres para agregar módulos constructivos.

- se encuentren en terrenos adquiridos mediante operatorias nacionales, provinciales o municipales destinadas a la provisión de terreno e infraestructura exclusivamente.

Se otorga prioridad a aquellos propietarios que habitan viviendas con mayor índice de personas por dormitorio, así como también situaciones tales como la presencia en el hogar de miembros de la familia con capacidades motoras diferentes, hogares compuestos exclusivamente por ancianos en situación crítica, entre otros.

Modalidad de ejecución: las obras son contratadas por los municipios mediante licitación pública de acuerdo con la Ley Provincial 6.021. En el caso de localidades del interior, está previsto que se realicen por administración.

Financiamiento: Las intervenciones se realizan con aporte de fondos del Estado Nacional.

Reintegro: Los destinatarios reintegrarán las inversiones que se realicen en sus viviendas en 600 cuotas mensuales iguales y consecutivas, que serán percibidas por los Municipios y dichos montos pasarán a formar parte del Fondo Municipal para la Vivienda, con el fin de ser reinvertidos en programas de viviendas.

Proyecto y documentación técnica: Equipos de Gestión y Proyecto, municipios, e IVBA.

El IVBA provee un manual de proyecto con un menú de opciones de módulos a utilizar de acuerdo a la necesidad de cada vivienda: baño, baño-cocina, dormitorio, cocina-comedor, baño y dormitorio.

Organización: Los Municipios conforman Equipos de Gestión de Proyectos (EGP), compuestos por un profesional de la construcción, Arquitecto, Ingeniero, Maestro Mayor de Obras, Técnico Constructor, y de áreas sociales, Licenciado o Técnico en Trabajo Social o afín, los cuales tienen a su cargo grupos de cuarenta mejoras por equipo. El EGP tiene a su cargo el desarrollo del proyecto en todas sus instancias: relevamiento, selección de destinatarios, formulación, ejecución y post-ejecución. 
El Subprograma Federal de Integración Comunitaria además de la producción de viviendas incorpora obras que tienen que ver con el mejoramiento del hábitat y con la conformación del barrio; esto asociado a la generación de empleo contribuye a la inclusión social.

Objetivos:

- contribuir al desarrollo y mejoramiento de las condiciones del hábitat, vivienda, infraestructura básica y equipamiento comunitario de los hogares con Necesidades Básicas Insatisfechas y grupos vulnerables en situación de emergencia o marginalidad.

- promover la incorporación de mano de obra proveniente, fundamentalmente, de pobladores desocupados organizados en Cooperativas de Trabajo,

- procurar la reinserción social y laboral de la población destinataria.

Movilizar mercados locales de materiales e insumos para la construcción.

Organismos intervinientes: Ministerio de Planificación Federal, Inversión Pública y Servicios de la Nación; IVBA; Ministerio de Desarrollo Social; Ministerio de Salud y Ambiente; Ministerio de Trabajo, Empleo y Seguridad Social; Municipios de la Provincia de Buenos Aires.

Líneas de Acción: Construcción de Viviendas Nuevas. Mejoramiento de Viviendas Recuperables. Mejoramiento del Hábitat Urbano, Obras de Infraestructura y Complementarias. Equipamiento Comunitario, Centros Integradores Comunitarios y Otros.

Usuario: población con Necesidades Básicas Insatisfechas y grupos vulnerables Miembros de las Cooperativas.

Criterios de elegibilidad de los proyectos:

- Que contribuyan a satisfacer las NBI de la población a la cual están dirigidas las obras.

- Atiendan al máximo posible la demanda de mano de obra de las Cooperativas de Trabajo.

- Contemplen las superficies mínimas que establecen las diferentes líneas de acción, como así también los "Estándares Mínimos de Calidad para viviendas de interés social" establecidos por la Subsecretaría de Desarrollo Urbano y Vivienda.

- Una razonable justificación técnica y económica.

- Proyectos integrales que prevean la infraestructura necesaria para la ejecución de las obras. 
Modalidad de ejecución: el Municipio actúa como ente ejecutor de las obras realizadas por las Cooperativas de trabajo.; que es quien tiene a su cargo la organización del programa tanto en el aspecto técnico, social y financiero a través de una Comisión Específica Municipal creada a tales efectos.

Financiamiento: se realiza con Fondos Nacionales, a través de la Subsecretaría de Vivienda y Desarrollo Urbano con desembolsos parciales al IVBA y de éste a los Municipios conforme al avance físico de las obras. Éstos comprenden materiales, mano de obra y subsidios para herramientas.

Reintegro: los destinatarios pueden reintegrar el valor de las inversiones en hasta en 600 cuotas mensuales iguales y consecutivas, con una tasa subsidiada efectiva anual del cero por ciento.

Proyecto y documentación técnica: para el caso de vivienda nueva el Programa contempla la construcción de viviendas de 44 a 70 metros cuadrados. El Instituto dispone de prototipos para ser utilizados de acuerdo a los requerimientos del Programa o pueden ser presentados por los Municipios.

El Subprograma Federal de Reactivación pretende reactivar los planes de vivienda financiados con los recursos provenientes del FONAVI y ejecutados por los organismos provinciales de vivienda cuyo margen de avance en obras es de un nivel muy bajo o se encuentran paralizadas. Se propone, además, contribuir a la generación de empleo a través de la inserción de mano de obra actualmente desocupada dentro del mercado laboral.

Objetivo: terminar las obras comprendidas en el subprograma con el aporte comprometido por la Nación con el fin de aprovechar los aportes para generar trabajo, uno de los requisitos para ingresar al subprograma es la incorporación formal de las empresas constructoras.

Organismos intervinientes: Ministerio de Planificación Federal, Inversión Pública y Servicios de la Nación; IVBA; Entidades Sin Fines de Lucro (ESFL) con Convenios Bonaerense II Solidaridad firmados y/o en Ejecución; Municipios de la provincia de Buenos Aires con Convenios Bonaerense II Solidaridad firmados y/o en Ejecución.

Usuario: los sectores de la población que cuenten con ingresos y con alguna capacidad de pago organizados a través de Entidades o Municipios. Modalidad de ejecución: Subcontratos con empresas constructoras. Financiamiento: Para el subprograma Reactivación un 50 por ciento aporta la Nación y otro 50 la Provincia. 
Reintegro: los destinatarios reintegrarán el aporte del IVBA en 300 cuotas o podrán cancelar anticipadamente su totalidad.

Organización:

- Con Municipios: descentralización en la ejecución de las obras mediante la transferencia de fondos en carácter de anticipo para la adjudicación de materiales y mano de obra, promoviendo la autogestión de los sectores involucrados en todas las etapas del Programa.

- Con Entidades: tiene como objetivo general explicitar los lineamientos principales que norman a las entidades sin fines de lucro en los aspectos generales y particulares para lograr una correcta aplicación, promoviendo así la autogestión de los sectores participantes, fundamentalmente el usuario. La diferencia con el programa entre Municipios es que la Entidad deberá ceder al IVBA la titularidad del inmueble presentado previa acreditación como tal de su dominio.

Proyecto y documentación técnica: el IVBA desarrolló y puso a disposición de los equipos técnicos de los municipios distintos prototipos de vivienda básicamente de 32 metros cuadrados cubiertos, asistiéndolos técnicamente en otros casos para su desarrollo y en la etapa de formulación de los respectivos proyectos urbanos. En el caso de las ESFL los proyectos pueden ser desarrollados por las mismas Entidades y el Instituto procede al otorgamiento del respectivo Certificado de Aptitud Técnica (CAT).

Cabe destacar la evaluación de la aplicación del Plan Federal de Construcción nueva (Perkins, 2007), realizado por licenciadas en trabajo social que se desempeñan en el área social del IVBA, en el año 2007, quienes estudiaron los barrios construidos y entregados total o parcialmente; por un lado en el Gran Buenos Aires, en Florencio Varela (barrio Santa Rosa entrega parcial de 440 de 880 viviendas) y Esteban Echeverría (barrio Ceferino Namuncurá entrega parcial de 192 de 1990 viviendas) donde se evidencia que si bien la mayoría de las familias expresan haber mejorado su situación habitacional aún no han logrado acceder a un hábitat digno, dada la ausencia o deficiencia en los barrios de servicios educativos, sanitarios, recreativos, de transporte, lo que implica un avance cuantitativo del plan en lo que respecta a la construcción de las viviendas pero no en lo social dado el aislamiento y marginación que produce no disponer de dicha infraestructura para las familias que no pueden sortear estas dificultades, por lo tanto se da la concreción del derecho a la vivienda pero no a la ciudad. 
Y por otro lado realizaron el estudio en el interior provincial, en los partidos de Necochea y Lobos, que con menor cantidad de viviendas (558 de 704 viviendas en Necochea y 95 de 445 viviendas en Lobos) fueron ejecutados en distintos emplazamientos, integrados a la trama urbana y de fácil acceso a los distintos servicios de la ciudad, donde las familias manifiestan estar conformes con la nueva vivienda aunque en el caso de Necochea resaltan graves problemas de obra (rajaduras, humedad y falta de desagües pluviales) que llegaron a ocasionar la evacuación de algunas familias.

En todos los proyectos analizados, las familias destinatarias no participaron en el diseño del actual hábitat, no se contemplaron situaciones de discapacidad en las construcciones y las dimensiones de las viviendas son reducidas en cuanto a la cantidad de miembros que albergan y si bien permite el crecimiento de un dormitorio, dicha ampliación se ve dificultada por las características socio económicas de las familias dados sus escasos recursos.

Además, la evaluación incluye una apreciación sobre la tardía intervención del área social del IVBA en la operatoria. La intervención de este equipo se dispuso recién cuando las obras estuvieron licitadas y algunas en ejecución impidiendo cumplir con la función de coordinar las etapas del proceso de adjudicación. Esto se debió a la escases de lineamientos del Plan y la dificultad de articulación de las áreas intervinientes del IVBA para consensuar propuestas conjuntas de intervención sumada a la dificultad en la articulación del IVBA con los municipios y la Nación. Cabe aclarar que dicha evaluación no fue tomada en cuenta por las autoridades del IVBA.

También es interesante el Informe de Auditorías de Obras del Plan Federal realizado por arquitectos e ingenieros del IVBA, en el año 2008, (Besada, 2008) donde de un total de 43 obras y 15.527 viviendas (dentro de las que están incluidas las anteriormente mencionadas) se puede observar que existen fallas que tienen importancia por el alto porcentaje de concurrencia y por la falencias de seguridad que implica:

\begin{tabular}{|l|l|}
\hline$\%$ & $\begin{array}{l}\text { Fallas por Orden de Concurrencia en } \\
\text { las Obras }\end{array}$ \\
\hline 85 & cubiertas putrescibles \\
\hline 60 & presencia de arroyos cercana \\
\hline 42 & falencias en anclajes de techos \\
\hline
\end{tabular}




\begin{tabular}{|c|c|}
\hline$\%$ & $\begin{array}{l}\text { Fallas por Orden de Concurrencia en } \\
\text { las Obras }\end{array}$ \\
\hline 31 & mampostería de mala calidad \\
\hline 30 & gabinetes de gas- puertas deteriorados \\
\hline 28 & falta de nexos \\
\hline 27 & presencia de líneas de alta tensión cercana \\
\hline 20 & ausencia de refuerzos estructurales \\
\hline 20 & mala calidad de revoques \\
\hline 16 & presencia de cavas cercana \\
\hline 15 & mala terminación de veredas \\
\hline 13 & falta o discontinuidad de encadenado superior \\
\hline 9 & fundaciones sin preparar el suelo \\
\hline 8 & ventilación cloacal antirreglamentaria \\
\hline 7 & ladrillos huecos mal colocados \\
\hline 5 & mala calidad y desprolijidad en carpetas \\
\hline 5 & mala calidad y desprolijidad en revoques \\
\hline 5 & falta de estudios de niveles de conjunto \\
\hline 4 & sobrecertificación \\
\hline 2 & falencias en tanques de agua \\
\hline 2 & carpinterías inadecuadas \\
\hline
\end{tabular}

Porcentaje de concurrencia de fallas de obras

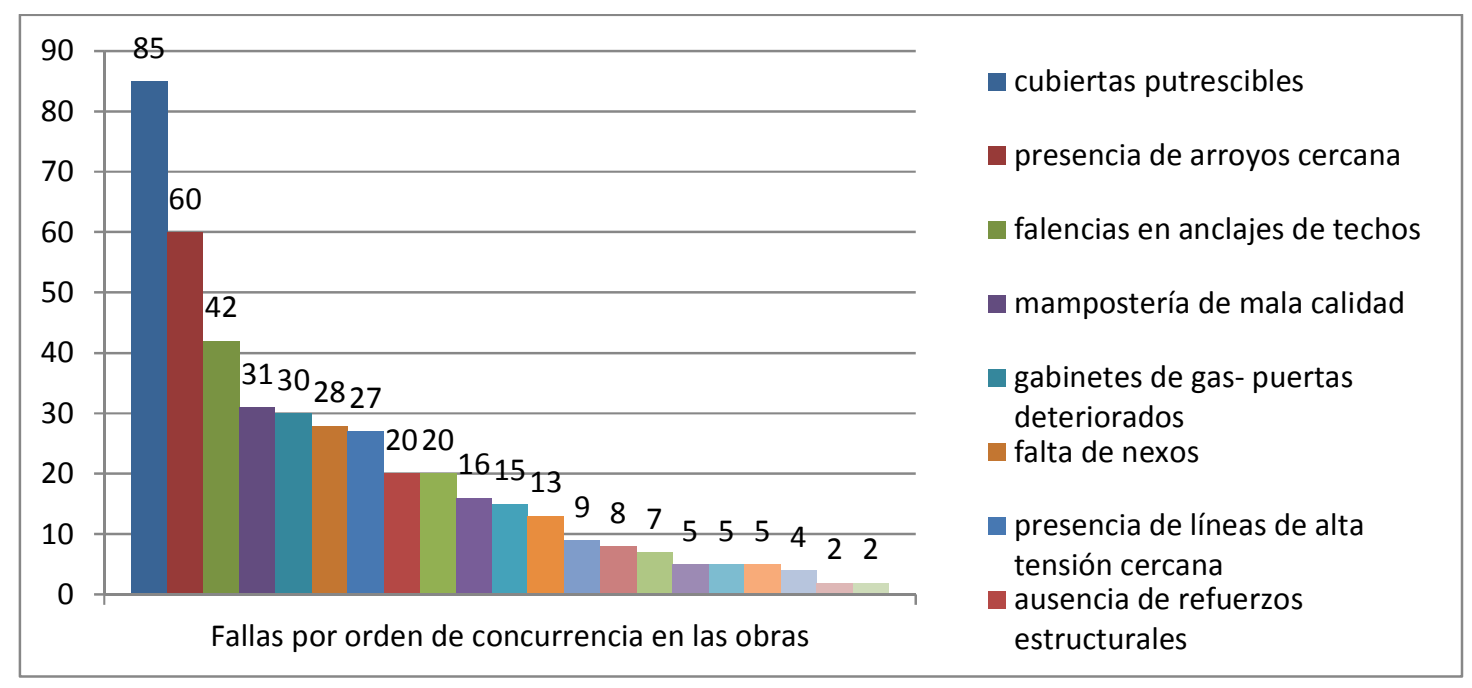


Como conclusión podríamos decir que si bien con los Planes Federales se produce desde la política un avance en la efectivización del derecho a la vivienda dada la cantidad de soluciones habitacionales producidas, también se observa que en la práctica en una misma vivienda se producen la concurrencia de más de una falla de obra, evidenciándose un derecho recortado a una vivienda de cierta calidad que va en detrimento en pos de la cantidad.

\section{Operatorias Provinciales de este período:}

- Programa Nuestra Casa. Subprograma Policía Comunal y Distrital.

- Programa Solidaridad. Modalidades: Solidaridad con Municipios, Solidaridad con Entidades sin Fines de Lucro, Vivienda Rural y Con criterios bioclimáticos.

- Programa Lotes con Servicios.

- Programa Buenos Aires Hogar.

El Programa Provincial Nuestra Casa brinda el acceso a la vivienda propia a grupos familiares con capacidad de ahorro y aquellos que poseen lote propio a través del cofinanciamiento con los municipios. Cuenta con una inserción adecuada en el medio físico-ambiental, acompaña el crecimiento residencial, incluyéndose en la trama de la ciudad sin distorsionar la capacidad de la infraestructura básica.

El Subprograma Policía Comunal y Distrital: facilita el acceso a la vivienda propia la radicación del núcleo familiar de los agentes que revistan en la Policía Comunal y Distrital.

Financiamiento: el importe a financiar es del 100\%.

Reintegro: el destinatario reintegrará el aporte financiero al IVBA en 300 cuotas mensuales, mediante descuento de sus haberes.

El Programa Solidaridad posibilita el acceso a una asistencia financiera que permite mejorar la calidad de vida de los grupos familiares destinatarios a través de la construcción de viviendas nuevas, realización de obras de completamiento para mejorar la habitabilidad, ampliación y/o terminación de las viviendas y de sus infraestructuras. Existen cuatro modalidades: solidaridad con municipios, solidaridad con entidades sin fines de lucro, vivienda rural y con criterios bioclimáticos. 


\section{Solidaridad con Municipios:}

Objetivos:

- Generar el desarrollo de las economías regionales y locales.

- Propiciar la ocupación de la mano de obra local.

- Incentivar la especialización de las capacidades técnicas.

- Optimizar la infraestructura básica existente.

- Fortalecer la presencia del gobierno local.

- Atender a sectores de la población en emergencia social.

Organismos intervinientes: IVBA; municipios de la provincia de Buenos Aires. Usuario: grupos familiares que carecen de vivienda propia, con escasa capacidad de ahorro o sin patrimonio suficiente para resolver la carencia de ella, exclusivamente por sus propios medios.

Modalidad de ejecución: los municipios realizan las obras por administración o a través de terceros, mediante las modalidades habituales de contratación. Los terrenos, dominialmente saneados, deben ser transferidos al Instituto de la Vivienda, previo al comienzo de las obras.

Financiamiento: la ejecución de las viviendas se realiza con un aporte del $100 \%$ por parte del Instituto de la Vivienda, sin financiamiento de las obras de infraestructura, salvo aquellos casos que la Asistencia Financiera esté dirigida al financiamiento de las mismas.

Reintegro: los destinatarios reintegrarán el aporte del IVBA en cuotas trimestrales en un plazo de quince años.

Organización: el programa prevé la descentralización en la ejecución de las obras mediante la transferencia de un porcentaje de los fondos acordados en carácter de anticipo financiero y luego desembolsos por certificaciones, conforme al avance de las obras.

Proyecto y documentación técnica: los municipios presentan la documentación técnica de las obras necesaria para perfeccionar el respectivo Convenio y su evaluación es realizada por el Instituto de acuerdo a las pautas de evaluación establecidas de modo de garantizar que las obras lleguen a su término en los tiempos y las formas establecidos en los respectivos Convenios. 


\section{Solidaridad con entidades sin fines de lucro:}

Objetivos:

- Facilitar la recuperación y renovación de áreas urbanas, terminación, ampliación y construcción de viviendas en urbanizaciones y lotes propios de los destinatarios.

- Promover el trabajo en conjunto con las Organizaciones Sociales.

- Fortalecer las Organizaciones Barriales.

Organismos intervinientes: IVBA; entidades sin fines de lucro adherentes al Programa. Usuario: grupos familiares que carecen de vivienda propia, con escasa capacidad de ahorro o sin patrimonio suficiente para resolver la carencia de ella, exclusivamente por sus propios medios.

Modalidad de ejecución: las Entidades realizan las obras por sí o por contratación de terceros. Los terrenos, dominialmente saneados, deben ser transferidos al Instituto de la Vivienda, previo al comienzo de las obras.

Financiamiento: la ejecución de las viviendas se realiza con un aporte del $100 \%$ por parte del Instituto de la vivienda, sin financiamiento de las obras de infraestructura, salvo aquellos casos que la asistencia financiera esté dirigida al financiamiento de las mismas.

Reintegro: los destinatarios reintegrarán el aporte del IVBA en cuotas trimestrales en un plazo quince años.

Organización: el Programa prevé la descentralización en la ejecución de las obras mediante la transferencia de un porcentaje de los fondos acordados en carácter de anticipo financiero y luego desembolsos por certificaciones, conforme al avance de las obras.

Proyecto y documentación técnica: las entidades presentan la documentación técnica de las obras necesarios para perfeccionar el respectivo convenio y su evaluación es realizada por el Instituto de acuerdo a las pautas de evaluación establecidas de modo de garantizar que las obras lleguen a su término en los tiempos y las formas establecidos en los respectivos Convenios.

\section{Vivienda Rural:}

Objetivos:

- Posibilitar el acceso a la vivienda a pequeños productores y empleados rurales de escasos recursos en áreas rurales o semi rurales.

- Generar el desarrollo de las economías regionales y locales. 
- Propiciar la formación agrícola del pequeño productor.

- Favorecer la capacitación de mano de obra para la construcción.

Organismos intervinientes: Ministerio de Asuntos Agrarios; IVBA; Municipios de la Provincia de Buenos Aires. A través de un trabajo en conjunto, el Ministerio de Asuntos Agrarios capacita al pequeño productor rural, el IVBA provee la asistencia técnica para la autoconstrucción de la obra y el Municipio la administra comprando materiales y realizando la dirección mediante en equipo técnico-social.

\section{Vivienda con criterios bioclimáticos:}

Objetivos:

- Resolver las necesidades básicas de habitabilidad en una superficie tipo construida, implementando pautas bioclimáticas probadas.

- Efectuar uso eficiente de la energía con la consiguiente reducción de gastos de funcionamiento.

- Incorporar equipamientos alternativos aplicando energías no convencionales a efectos de proteger el medio ambiente.

Organismos intervinientes: Instituto Nacional de Tecnología Industrial; Facultad de Arquitectura y Urbanismo de la Universidad Nacional de La Plata; Municipios de la provincia de Buenos Aires; IVBA.

El Programa Lotes con Servicios facilita el acceso al suelo urbanizado de familias de bajos ingresos construyendo urbanizaciones planificadas. Promueve el completamiento de la trama urbana y prevé la habilitación de tierra apta para el uso residencial, incorporando infraestructura básica de servicios y espacios verdes recreativos.

Objetivos:

- Optimizar los recursos disponibles con el objeto de obtener el mayor número de soluciones habitacionales.

- Articular a los actores que intervienen en la construcción del Hábitat Social en pos de un resultado común.

- Promover la actividad económica de los bordes peri-urbanos y aumentar la demanda de mano de obra.

- Reducir el costo final del lote con servicios básicos y la vivienda.

- Habilitar tierra apta para uso residencial.

- Incorporar infraestructura básica (agua potable, energía eléctrica, alumbrado público, apertura de calles y desagües pluviales). 
- Construir Espacios Verdes recreativos.

- Gestionar equipamiento comunitario.

Organismos intervinientes: Subsecretaría Urbanismo y Vivienda; Subsecretaria Social de Tierras; IVBA; Municipios de la Provincia de Buenos Aires; Entidades Intermedias.

Usuario: Familias sin vivienda con compromiso de efectivo y permanente ocupación de la parcela y de destinar el inmueble a vivienda familiar seleccionadas por los municipios / entidades intermedias.

Modalidad de ejecución: construcción de redes de servicios domiciliarios por administración, a través de cooperativas o empresas constructoras contratadas por licitación pública realizada por los propios municipios o por entidades. Los terrenos son aportados por los municipios/entidades intermedias.

Financiamiento: a cargo del Instituto de Vivienda de la Provincia de Buenos Aires.

Adjudicación: las familias destinatarias son seleccionadas por el Municipio o Entidad intermedia.

Reintegro: hasta 180 cuotas, con interés del diez por ciento (10\%) de la tasa nominal anual vencida para préstamos hipotecarios que percibe el Banco de la Provincia de Buenos Aires a la fecha de la firma del convenio particular, con garantía de coparticipación de los municipios e hipoteca en primer grado cuando se trate de entidades intermedias.

Organización: el municipio determina la forma organizativa en base a su legislación; es el responsable del correcto destino de los fondos invertidos.

Proyecto y Documentación Técnica: elaborada por los municipios y/o entidades intermedias con asistencia técnica del Instituto de la Vivienda, cuando así lo requieran.

El Programa Buenos Aires Hogar apunta a que las personas puedan contar con su vivienda propia, en condiciones dignas, adaptadas a las características del grupo familiar y en armonía con el entorno local.

Objetivo: asegurar el desarrollo de la comunidad y garantizar la equidad en la asignación de los recursos públicos.

Organismos intervinientes: Ministerio de Infraestructura, Banco Provincia de Buenos Aires, Fondo Fiduciario para el desarrollo del Plan de infraestructura provincial y el IVBA de la provincia de Buenos Aires.

Usuario: personas físicas que acrediten adecuada capacidad legal, patrimonial, económica y financiera.

Modalidad de ejecución: por licitación pública. 
El municipio aporta el terreno, ejecuta la mensura y subdivisión de los mismos, acredita que los predios cuenten con la zonificación adecuada, la aptitud hidráulica y la infraestructura residencial básica. El Fondo Fiduciario para el Desarrollo del Plan de Infraestructura provincial otorga el financiamiento. El IVBA subsidia la tasa de interés que fije el Banco.

Financiamiento: el Fondo Fiduciario para el desarrollo del Plan de Infraestructura provincial financia el $100 \%$ de la construcción de las viviendas.

Adjudicación: las familias destinatarias son seleccionadas por los municipios. El listado es enviado al IVBA quien analiza y verifica la documentación para luego enviarla al Banco de acuerdo a los requisitos establecidos.

Reintegro: los destinatarios reintegran el crédito hasta 240 meses a través de cuotas mensuales.

Organización: los municipios interesados deben presentar su propuesta ante el Ministerio de Infraestructura. El IVBA controla la obra -los materiales, la ejecución de los trabajos, el avance de la misma- y el cumplimiento de los requisitos para ser beneficiario de una vivienda social.

Proyecto y documentación técnica: debe cumplir con las normas Municipales y Provinciales vigentes y se prevé un sistema constructivo tradicional racionalizado aprobado por Nación o Provincia.

Cabe citar el Informe sobre el Programa Buenos Aires Hogar realizado por Eduardo López en 2013, que observó que al momento de decidirse la gestión del programa en el discurso de los funcionarios municipales no aparece la necesidad de incorporar a los "beneficiarios" de la política social a la gestión de la misma (en la definición de cómo, dónde o con qué vecino habitará) ni de tener en cuenta sus particularidades; el discurso hegemónico entre los decisores es de racionalidad tecnocrática, con una planificación normativa, una toma de decisiones burocrática basada en la una producción realizada por la empresa privada. Esta mirada supone una población solvente que no reclama decidir dónde o como vivir aceptando pasivamente el diseño arquitectónico y el crédito estandarizados. Además se registra una inadecuación sistémica entre oferta y demanda, sin tener en cuenta el bajo nivel de satisfacción de la misma. En dicho discurso tampoco aparece el derecho a la ciudad y la concepción de déficit habitacional es cuantitativa y "viviendista" sin importar el lugar de emplazamiento y de cómo las urbanizaciones se inscriben y vinculan a la trama urbana. 
Este período puede resumirse en el siguiente cuadro y gráficos que muestran las Operatorias/Programas del IVBA y su cantidad de viviendas y tamaños de las mismas.

\begin{tabular}{|c|c|c|c|c|c|c|}
\hline Operatoria/Programa del IVBA & & & & & & \\
\hline Período 2003 al 2009 & Años Vigenc & Ejecución & Financiamiento & Usuario & Metros $2 \times$ Viv & Viviendas \\
\hline Federal & $2006-2009$ & const $x$ empresas constr & IVBA-Gob.Nac. & demanda gral de munic. & 44 & 6,495 \\
\hline Federal con Municipios & 2006-2009 & const $x$ empresas constr & IVBA-Gob.Nac. & demanda gral de munic. & 44 & 13,634 \\
\hline Mejor Vivir & $2004-2009$ & const $x$ munic $x$ lic obra 0 & IVBA-Gob.Nac. & demanda gral de munic. $c / v$ & 44 & 72 \\
\hline Emergencia Habitacional & $2006-2009$ & const $x$ munic $x$ coop de & IVBA-Gob.Nac. & habitantes c/ NBI y miembr & 44 & 704 \\
\hline Urbanización de Villas & $2006-2009$ & const $x$ IVBA o munic $x$ II & IVBA-Gob.Nac. & habitantes de villas o asent & 44 & 3,622 \\
\hline
\end{tabular}

Cantidad de viviendas construidas en el período 2003-2009

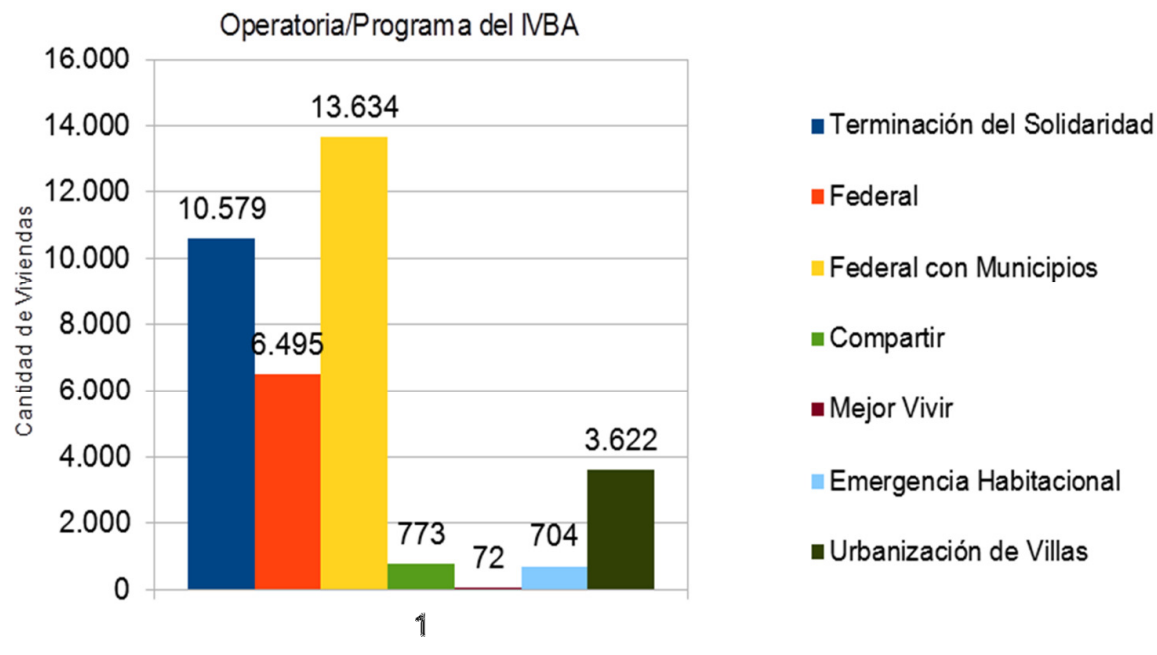

Superficie de viviendas construidas en el período 2003-2009

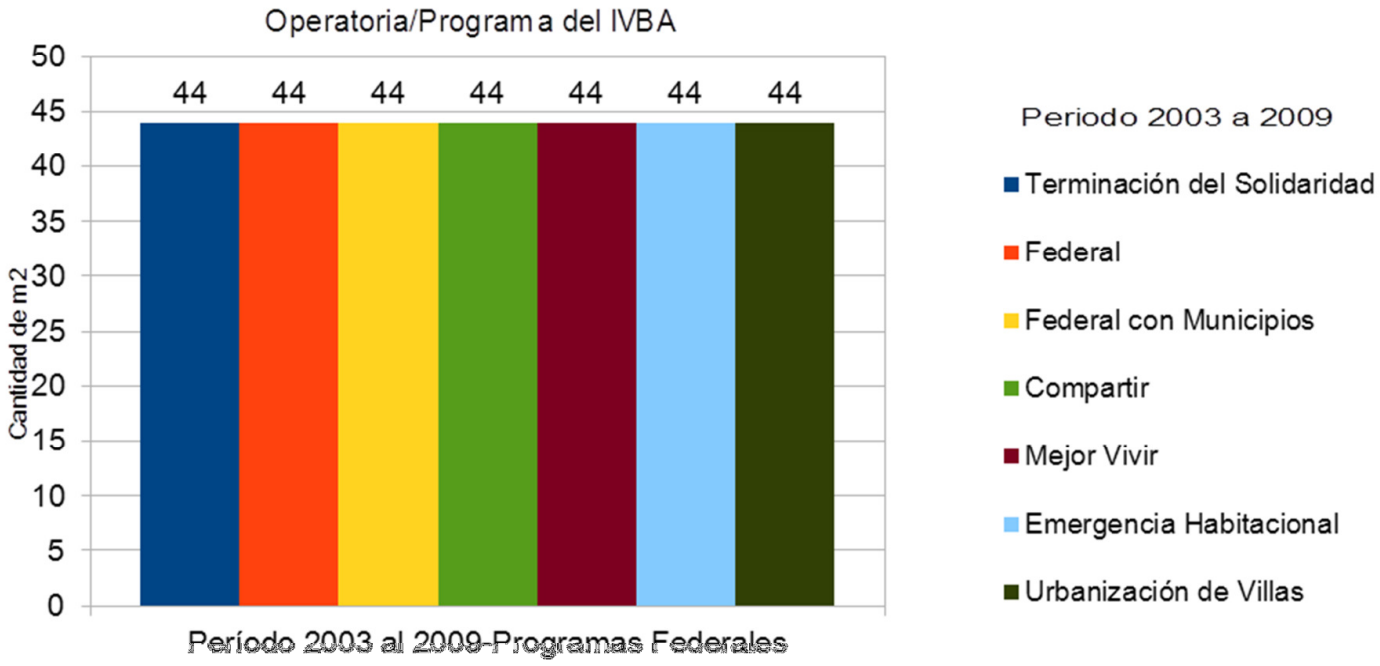

Como conclusión de este período de 2003 a 2009, en seis años, el IVBA a través del Programa Federal con Municipios y luego del Terminación del Solidaridad muestra un avance en la efectivización del Derecho a la vivienda. En este Modelo de Acumulación 
Económica en transición al Productivo con Políticas Habitacionales de tipo neokeynesianas y neoestadocéntricas se realiza una construcción de gran cantidad de soluciones habitacionales. A pesar de estos avances, la cantidad de viviendas va en detrimento de la calidad de las mismas, porque si bien están preparadas para su ampliación, la disminución en la superficie promedio a 40 metros cuadrados incide en la calidad de vida de sus habitantes. También existe todavía una postergación en la implementación del derecho a la ciudad (centralidad y cercanía a la trama urbana) dada la ubicación periférica de la mayoría los barrios.

Para establecer una comparación entre los Planes Habitacionales ${ }^{8}$ en cuanto a la cantidad de viviendas construidas los que se manifiestan como mejores son los FONAVI y los Federales, los que tienen que ver con entidades, los Solidaridad y ProCasa. Este último con menor cantidad de viviendas y más adaptado a las necesidades de la gente (dada una relación más directa con las personas y su participación).

Los FONAVI y los FEDERALES son los planes más importantes por la cantidad de viviendas construidas, sin embargo la gente no participaba y no estaban adaptados a sus necesidades.

Los FONAVI si bien tenían en cuenta al grupo familiar, ya que según la cantidad de miembros de las familias, las viviendas tenían tres o cuatro dormitorios estaban insertadas en grandes complejos, con plantas depuradoras, ascensores y espacios comunes que implicaban un mayor mantenimiento. Lo cual hacía que con el paso del tiempo dado el deterioro edilicio la satisfacción de la gente descendiera.

Así los FONAVI, dados los grandes conjuntos habitacionales construidos entonces, hoy presentan una situación de deterioro físico y social debido a distintos problemas, entre otros, un significativo descenso de los niveles de calidad constructiva, imprevisiones de proyecto con relación a su posterior uso y mantenimiento, y la paulatina caída de los niveles de ingreso de sus habitantes.

${ }^{8}$ Información obtenida de la entrevista grupal realizada a las Lic. En T.S. Silvia Caggiano, Nora Perkins, Soledad Cárdenas y Marisa Biglia 
Los FEDERALES dan soluciones habitacionales en cantidad pero no tenían en cuenta al grupo familiar, por tratarse de viviendas más pequeñas aunque con una tipología más acertada de vivienda única de una o dos plantas.

En la época de los FONAVI el IVBA realizaba todas las funciones mencionadas anteriormente, donde se mantenía un contacto directo con la personas y a las trabajadoras sociales del IVBA se las reconocía como "las chicas del FONAVI" pero en tiempos de los FEDERALES ya con la descentralización a los municipios, el IVBA solo realizaba auditorías que en 2007 quedaron también libradas a dichos municipios. La paulatina pérdida de autonomía y funciones, tales como los aportes del área social y como la de asesorar al gobernador sobre la política de vivienda y su financiamiento termina desdibujando al IVBA (por decreto provincial 502/04 todo debía pasar por el Ministro de Infraestructura y Servicios Públicos para su rúbrica).

Orgánicamente desde las autoridades del IVBA a lo largo del tiempo no se propició trabajar en forma transversal por las distintas direcciones y departamentos que lo conforman. En este aspecto hay que rescatar y destacar los niveles de conducción intermedios como jefes de departamento y directores de carrera, que a iniciativa propia y de sus empleados, en algún momento intentaron trabajar conjuntamente, donde se organizaron jornadas para coordinar la acción de algunos departamentos, pero no tuvo continuidad (como por ejemplo el Programa Único Nuestros Barrios- Nuestros Pueblos diseñado en 2003 aproximadamente por el departamento de social y de política habitacional pero que no se implementó, y otras propuestas como las mencionadas anteriormente del AVE, SEHAS, CEVES que no llegaron a desarrollarse, tal vez porque a los intereses de las empresas constructoras crecientes en esta etapa no les convenía).

La falta de coordinación entre las actuales direcciones generales fue una marca de la trayectoria del IVBA, cada vez con menos funciones de política, de estadísticas que permitan estudiar la demanda de las familias con qué proyectos y obras se trabajará para darles una solución habitacional.

A lo largo del tiempo fueron temas de debate entre los inspectores, agrimensores, arquitectos y los trabajadores sociales la búsqueda de barrios autosustentables, ya que llegaban a las mismas conclusiones detectando los mismos problemas de aprobar planes 
con tantas viviendas siendo conveniente realizar consorcios más pequeños con mayor participación de las personas y con un diseño en base a las necesidades de las mismas.

Para el caso de los FONAVI dados los escasos recursos de las personas sobre todo con los vaivenes de la economía argentina con la pérdida de empleo de los '90 se les hacía difícil mantener los costos de los complejos habitacionales en cuanto a la expensas (servicios de luz, ascensor, planta depuradora, y torre de tanque) y cuando no han podido pagar no se pudo mantener con la consiguiente pérdida de valor del bien y de habitabilidad por su deterioro y abandono.

Para el caso de los FEDERALES sería interesante reemplazar el prototipo de 44 metros cuadrados (de dos dormitorios) al que luego hay que hacerle ampliaciones, por uno que tenga en cuenta al tamaño de las familias y se construya de una sola vez (para no tener que estar agrandando después a mas dormitorios con nuevas empresas que desde el punto de vista de los costos no resulta más económico).

La realización de evaluación del Plan Federal en su primer etapa llevada a cabo por las trabajadoras sociales entrevistadas no fue tomada en cuenta por la Administración del IVBA de ese momento, no quisieron ver los errores ni tampoco darlos a conocer al resto del organismo, ni a los municipios que participaron, como si de esa manera no existieran.

La decisión de ejecutar la Política Habitacional proviene del gobernador de la provincia, con un presupuesto que se subejecuta, con gestiones que no realizan evaluaciones ni reconocen errores, es difícil avanzar hacia la efectivización del derecho a la vivienda, así hubo momentos históricos en donde se garantizó más o menos, mejor o peor, y se modificó qué se financia, hasta los ` 80 se privilegian las grandes empresas privadas, en los '90 las asociaciones intermedias y en menor medida los municipios, en los 2000 con los federales se privilegia a los municipios y cooperativas, y también las grandes empresas.

En los distintos momentos históricos se atendió a distintos estratos de población sin llegar a ser universal, por ejemplo con la operatoria del Banco Hipotecario SA se atendió a los sectores medios mientras que la población genuina a ser atendida es la de bajos recursos como la destinataria de los FONAVI y Federales, pero aun así existe una 
población que nadie atiende porque no existen operatorias para ellas como lo son las personas solas o sin grupo familiar y sin ingresos.

Con la operatoria del Banco Hipotecario SA (1720) se construyeron casa muy caras y no había a quien adjudicárselas porque la gente no podía pagar la cuota, por lo tanto el banco hipotecario prestaba el dinero al IVBA que a través de las empresas constructoras hacia las viviendas y después las entregaba subsidiando un porcentaje de la cuota que tenía que pagar el adjudicatario al banco, que todavía se sigue subsidiando.

Así siempre se dio una respuesta parcialmente según la impronta del gobierno de turno para beneficiar a un u otro sector. El IVBA al no estudiar la demanda no sabe a quién atender ni darle lo que necesita, con atribuciones delegadas a los municipios que hicieron lo que quisieron terminando por regularizar a la persona que estaba dentro de las viviendas sin garantizar el proceso de adjudicación.

Con la operatoria del $\mathrm{Federal}^{9}$ ingresaron los fondos de nación pero no se utilizaron en su totalidad debido a desfasajes en los tiempos, por pedidos de actualización de precios que hacían que se paralizaran las obras por falta de materiales y la empresa terminara abandonándolas y el IVBA pagando vigilancia para que no las intrusionen.

Esto tiene que ver con la decisión del gobierno provincial desde 2008, de colocar cupos en el departamento de Presupuesto para la salida de expedientes, en la Delegación de Contaduría, así en cada lugar se demoraban los expedientes de obras, por lo tanto para el pago de un certificado en vez de 20 días se tardaba tres meses, cada vez más burocracia para frenar el gasto provincial. Además a partir de 2004 con el decreto 502 todo acto que tenga que ver con los recursos del Estado bonaerense debía pasar por la rúbrica del Ministro de Infraestructura y Servicios Públicos (inversiones, contratos y convenios), con lo cual se perdía cada vez más la autarquía del IVBA, por otro lado también desde 2008 se dependía cada vez más del Ministerio de Economía, ya que el organismo como el resto de los organismos provinciales ingresó en el sistema de la CUT, cuenta única que transfiere diariamente el dinero ingresado en las cuentas bancarias del IVBA dejándolas en cero, y extrayéndolos como préstamos el gobierno provincial, utiliza los fondos destinados a vivienda para otros gastos como el pago de sueldos de otros organismos.

\footnotetext{
${ }^{9}$ Información obtenida de la entrevista realizada a Lucia Parletta, Jefa de Mov. de Fondos del Depto. Contable.
} 
El recupero de las cuotas con el transcurso de los años aumentó por mejoras en el proceso siendo más efectivo en el cobro de las mismas, el valor de las cuotas es fijo, dicho valor se obtiene del precio total de la obra (barrio) incluidas la infraestructura y las redeterminaciones de precios, dividido la cantidad de viviendas y los años en que se prorratea la cuota.

El Programa de Recupero de Fondos en Co-Gestión con Municipios, está destinado a promover una alianza con los municipios para optimizar el sistema de reintegro y generar una eficaz política de recupero de fondos (aunque esta mejora no implicó necesariamente mejoras de gestión). Este programa se aplica al: Plan Federal I de: Construcción de Vivienda, de Emergencia Habitacional Techo y Trabajo, Mejoramiento de Viviendas Mejor Vivir, Construcción de Viviendas con Municipios, con Entidades, urbanización de Villas y Asentamientos.

Una vez firmados los convenios el IVBA tiene a su cargo la emisión de las cuotas de amortización, la impresión de las boletas de pago y la rendición de la recaudación. Además, liquida los diferentes porcentajes de reintegro y en caso de ser necesario, asesora a cada municipio en aspectos financieros, legales e informáticos. El municipio, por su parte, es el encargado de la distribución y entrega de las boletas de pago, y asesoramiento al adjudicatario de la vivienda sobre la forma y lugares donde pueden abonarse las cuotas. Por otra parte, el sistema permite que la boleta sea abierta y se pueda realizar el pago de cuotas atrasadas o deuda existente, a fin de agilizar el trámite.

Si bien el presente trabajo abarca hasta el 2009, es a partir de allí en los años posteriores que se evidencia una menor cantidad de viviendas construidas analizando los estados contables con cada vez mayores resultados (es decir el dinero que sobra es creciente en millones de pesos año tras año). Así programas como el PROMEBA que consiste en un préstamo del BID que sirve solo para hacer infraestructura de barrios, y donde el IVBA debe pagar los intereses se use o no el dinero generando una deuda no tienen mucho sentido con un resultado positivo (sobrante de millones de pesos).

Endeudarse para pagar intereses y luego tener sobrante de fondos y seguir pagando deuda tiene que ver con una decisión política provincial, es algo impuesto donde el 
IVBA no tuvo decisión, lo mismo ocurrió con el Programa Plurianual de 2007 que utilizó fondos de la ANSES (con el agravante de ser fondos de jubilaciones) y las viviendas no se concluyeron.

Para terminar, integrando todas las operatorias en un cuadro que los compara a través de los parámetros seleccionados (cantidad de viviendas y metros cuadrados de las mismas) conforme al objetivo de visualizar los avances/retrocesos de la Política Habitacional en relación al derecho a la vivienda, se puede ver lo siguiente:

\begin{tabular}{|c|c|c|c|c|c|c|}
\hline Gestión del IVBA 1956-2009 & & & & & & \\
\hline Operatoria/Programa del IVBA & Años Vigenc & Ejecución & Financiamiento & Usuario & Metros & ivienda \\
\hline Período 1956 a 1976 & & & & & & \\
\hline Acción Cooperativa & 1957-1968 & construcción x cooperativas & IVBA-rentas grales & asociados de las coop & 70 & 450 \\
\hline Sistema de Asistencia Técnica Esfuerzo Propio y Ayudé & $1961-1976$ & construcción $x$ consorcios & IVBA-rentas gles. y & asoc. Del consorcio de lade & 70 & 2,670 \\
\hline Provincia y Municipios (PYM) & $1967-1975$ & construcción x munic. & IVBA-rentas grales & demanda gral del municipio & 45 & 4,212 \\
\hline Entidades Intermedias Plan Fed.Banco Hipotecario Nac. & $1968-1973$ & construcción $x$ ent.intermedia & Banco Hipotecario & demanda gral de Bahia Blar & 65 & 495 \\
\hline Entidades Intermedias ATEPAM x Coparticipación & $1971-1973$ & construcción $x$ atepam & IVBA-rentas grales & asoc.de las entidades & 64 & 243 \\
\hline Entidades Intermedias Decreto 3201/70 & $1971-1976$ & construcción $x$ ent.intermedia & IVBA-rentas grales & asoc.de las entidades & 65 & 300 \\
\hline Plan Erradicación de Viv Precarias PEVEP & 1971-1975 & constr.IVBA x lic pub y contrato de o & IVBA-Gob.Nac. & demanda gral del municipio & 68 & 501 \\
\hline Totales del Período & & & & & 64 & 8,871 \\
\hline Operatoria/Programa del IVBA & & & & & & \\
\hline Etapa 1976-1983 & Años Vigenc & Ejecución & Financiamiento & Usuario & Metros & ivienda \\
\hline FONAVI & $1976-1983$ & constr.IVBA $x$ lic pub y contrato de o & IVBA-FONAVI & demanda gral y/o asoc.de $e$ & 62 & 28,214 \\
\hline FOPROVI & $1980-1983$ & constr.IVBA x lic pub y contrato de o & IVBA-FOPROVI & demanda gral munic.o segú & 52 & 758 \\
\hline Provincia y Municipios(PYM) & $1978-1983$ & construcción $x$ munic. & IVBA-rentas grales & demanda gral del municipio & 45 & 1,558 \\
\hline Entidades Intermedias Decreto 3201/70 & 1971-1976 & construcción $x$ ent.intermedia & IVBA-rentas grales & asoc.de las entidades & 65 & 99 \\
\hline Alborada & $1974-1978$ & constr.IVBA x lic pub y contrato de o & IVBA-Gob.Nac. & demanda gral del municipio & 68 & 576 \\
\hline Totales del Período & & & & & 58 & 31,205 \\
\hline Operatoria/Programa del IVBA & & & & & & \\
\hline Etapa 1983 a 1992 & Años Vigenc & Ejecución & Financiamiento & Usuario & Metros & ivienda \\
\hline FONAVI & $1983-1992$ & constr.IVBA x lic pub y contrato de o & IVBA-FONAVI & demanda gral y/o asoc.de e & 62 & 30,475 \\
\hline FOPROVI & $1983-1992$ & constr.IVBA $x$ lic pub y contrato de o & IVBA-FOPROVI & demanda gral munic.o segú & 52 & 4,514 \\
\hline Autogestión Constructiva & 1985-1992 & const. $x$ muni o $x$ ent.interm. & IVBA-FOPROVI & demanda gral munic.o asoc & 40 & 2,985 \\
\hline Procasa & 1987-1992 & construcción x munic. & IVBA-FOPROVI & demanda gral del municipio & 40 & 2,705 \\
\hline ProCasa-Solidaridad-Vuelta al Pago-ProTecho-Reconstr & 1987-1992 & const. $x$ muni $0 x$ autoconstrucción & IVBA-FOPROVI & demanda gral muni.y/o asoc & 35 & 424 \\
\hline Totales del Período & & & & & 46 & 41,103 \\
\hline Operatoria/Programa del IVBA & & & & & & \\
\hline Etapa 1992 a 2003 & Años Vigenc & Ejecución & Financiamiento & Usuario & Metros & ivienda \\
\hline FONAVI & $1992-1996$ & constr.IVBA $x$ lic pub y contrato de o & IVBA-FONAVI & demanda gral y/o asoc.de e & 62 & 13,555 \\
\hline FOPROVI & $1992-1996$ & constr.IVBA $x$ lic pub y contrato de o & IVBA-FOPROVI & demanda gral munic.o segú & 52 & 70 \\
\hline Autogestión Constructiva & 1992-1999 & const. $x$ muni o $x$ ent.interm. & IVBA-FOPROVI & demanda gral munic.o asoc & 40 & 2,052 \\
\hline Procasa & 1992-1999 & construcción $x$ munic. & IVBA-FOPROVI & demanda gral del municipio & 40 & 5,206 \\
\hline ProCasa-Solidaridad-Vuelta al Pago-ProTecho-Reconstr & 1992-1999 & const. $x$ muni o $x$ autoconstrucción & IVBA-FOPROVI & demanda gral muni.y/o asoc & 35 & 468 \\
\hline Bonaerense I: Abuelos-Novios & 1992-1999 & const. $x$ munic o $x$ ent. interm. & IVBA-FONAVI-FOPI & demanda gral muni.y/o asod & 40 & 1,543 \\
\hline Bonaerense II: Solidaridad y sus subprogramas & 1992-1999 & const. $x$ munic o $x$ ent.interm. & IVBA-FONAVI-FOPI & Idemanda gral muni.y/o asod & 50 & 22,369 \\
\hline Bonaerense III: Financiamiento Compartido & $1992-1998$ & const. $x$ entidad. xemp.const. & $I V B A-F O N A V I-F O P I$ & asoc.de las entidades & 55 & 1,523 \\
\hline Bonaerense IV: Emergencia Habitacional & $1992-1999$ & const $x$ munci.xadm o cont.de obra & IVBA-FONAVI-FOPI & demanda gral de munic. & 40 & 719 \\
\hline Totales del Período & & & & & 46 & 47,505 \\
\hline Solo Descentralizadados* & & & & & & 26,154 \\
\hline Período 2003 al 2009 & & & & & & \\
\hline Terminación del Solidaridad & $2003-2009$ & const. $x$ munic $0 \times$ ent.interm. & & demanda gral muni.y/o asod & 44 & 10,579 \\
\hline Federal & $2006-2009$ & const $x$ empresas constr $x$ lic obra & IVBA-Gob.Nac. & demanda gral de munic. & 44 & 6,495 \\
\hline Federal con Municipios & $2006-2009$ & const $x$ empresas constr $x$ lic obra & IVBA-Gob.Nac. & demanda gral de munic. & 44 & 13,634 \\
\hline Compartir & 2007-2009 & const $x$ munic $x$ lic obra o adm & IVBA-Gob.Nac. & demanda gral de munic. & 44 & 773 \\
\hline Mejor Vivir & 2004-2009 & const $x$ munic $x$ lic obra o adm & IVBA-Gob.Nac. & demanda gral de munic. $c / v$ & 44 & 72 \\
\hline Emergencia Habitacional & $2006-2009$ & const $x$ munic $x$ coop de trabajo auto & IVBA-Gob.Nac. & habitantes c/ NBI y miembr & 44 & 704 \\
\hline Urbanización de Villas & 2006-2009 & const $x$ IVBA o munic $x$ lic obra o ad & IVBA-Gob.Nac. & habitantes de villas o asent & 44 & 3,622 \\
\hline Totales del Período & & & & & 44 & 35,879 \\
\hline Fuente:Dirección de Política Habitacional del IVBA. Conf & Afección Propia. & & & & & \\
\hline & & & & & & \\
\hline Nota 1: usuario con capacidad autoconstructora, ya que & aporta la mano & de obra. & & & & \\
\hline Nota 2: NBI: Necesidades Básicas Insatisfechas & & & & & & \\
\hline Nota 3: la Operatoria barrios obreros, barrios arquitectura & ra y Rurales no f & fueron tomados para el presente cuad & dra & ${ }^{\star \star M O S P}$ :Ministerio de Obras & Y Ser & cios Púb \\
\hline Nota 4: el corte del cuadro al 2009 se realizó arbitrariame & nente dada la dis & sponibilidad de los datos & & & & \\
\hline Nota 5: esta etapa contiene viviendas de la etapa centrali & & & & & & \\
\hline
\end{tabular}


Cantidad de viviendas construidas en el período 1956-2009
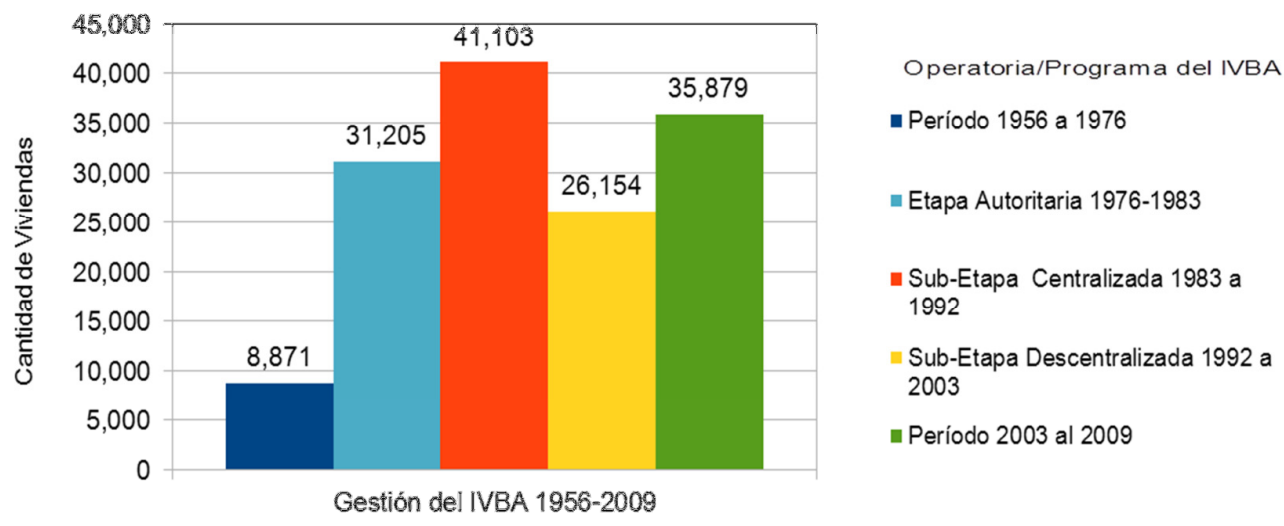

Superficie de viviendas construidas en el período 1956-2009

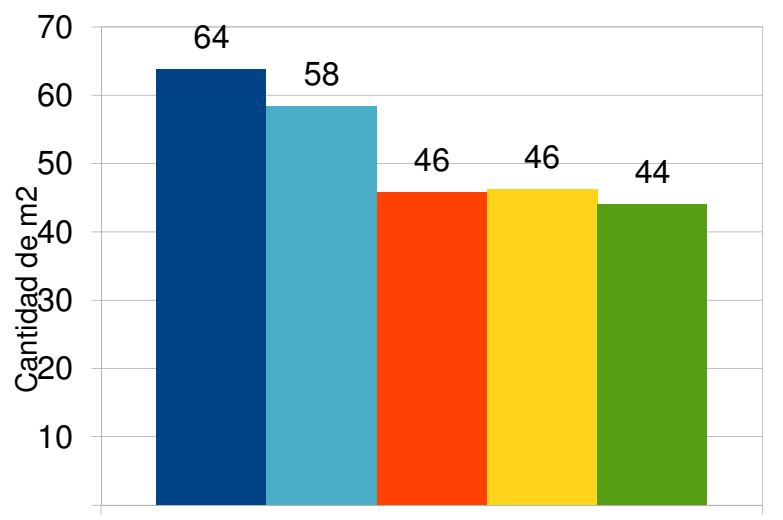

Operatoria/Programa del IVBA

- Período 1956 a 1976

- Etapa 1976-1983

- Etapa 1983 a 1992

Etapa 1992 a 2003

- Período 2003 al 2009

Gestión del IVBA 1956-2009

El anterior cuadro y gráficos permite observar que los períodos en que el IVBA gestiona una mayor construcción de viviendas son los períodos donde se centraliza la Política Habitacional a nivel nacional a través del FONAVI (de 1983 a 1992) y de los Planes Federales (de 2003 a 2009). En este último período y con una lógica diferente y de "derechos" en solo 6 años se llega a una proporción mayor (60,4 \% más) a lo producido por el sistema del FONAVI. Estos son los dos momentos históricos en que el IVBA a través de su política habitacional se acerca a la efectivización del derecho a la vivienda, ascenso en términos de cantidad de viviendas, aunque recortado en cuanto a la cantidad de metros por vivienda (si bien están preparadas para futuras ampliaciones) en el último de los períodos y aún sin efectivización del derecho a la ciudad. 


\section{Conclusiones}

La Política Habitacional en cada modelo de acumulación económica responde al entramado social, político e institucional de relaciones de fuerza y poder de los distintos actores en cada momento histórico (bloques sociales que lo impulsan defendiendo sus intereses), así el IVBA según el modelo hegemónico, las distintas formas de Estado dentro del mismo y las fuerzas sociales que se imponen tendrá una política habitacional que avanza o retrocede hacia la efectivización del derecho, a través de la provisión de vivienda social como redistribución de recursos para la igualdad.

Es decir, dependiendo de en qué medida los sectores populares han acumulado fuerza y están representados en el Estado en la época que se trate será la posibilidad que tengan para la efectivización del derecho y más aún en algunos momentos históricos (hasta 1983) la inestabilidad política muestra que la lucha por el derecho es parte de una lucha mayor a favor de la democracia en la sociedad.

El Instituto de la Vivienda Obrera, como antecedente provincial del IVBA, promueve la vivienda social económica como "ayuda" social en el marco de la construcción de cierto orden material y simbólico para los obreros del campo y la ciudad para evitar su movilización y el conflicto social.

Por su parte el IVBA se crea para el asesoramiento en la construcción de la vivienda, como objeto de tratamiento técnico especializado para reactivar la iniciativa privada, especialmente de cooperativas (formadas por familias de bajos recursos para acceder a la vivienda propia), a través del sistema de Asesoramiento Técnico Esfuerzo Propio y Ayuda Mutua (ATEPAM) financiado por rentas generales y la Agencia de Desarrollo Internacional (AID), en el marco de la Alianza para el progreso de EE.UU.; también, como su antecesor, para colaborar en la construcción de un orden social que evite la movilización y el conflicto social.

Si bien la gestión del IVBA va cambiando con los modelos de acumulación económica y las políticas habitaciones permitiendo avances o retrocesos en la efectivización del derecho a la vivienda, también existen algunas características que permanecen en todos los períodos como la modalidad tradicional típica de gestión del IVBA de tipo tecnocrática que se da sin la participación de los destinatarios en la gestación de las 
políticas y sin tener en cuenta sus necesidades particularidades (características sociales, económicas y culturales), con viviendas homogéneas lejanas a la ciudad. La expansión en términos de derechos a la vivienda dados en algunos períodos- etapas (por la cantidad de viviendas o soluciones habitacionales producidas) no avanzó a conquistar el derecho a la ciudad (es decir que se concreten los otros derechos). Algunas limitaciones en la modalidad de gestión del IVBA podrían estar relacionadas con su origen dado que continúa impregnado con algunas prácticas de su antecesor, el Instituto de la Vivienda Obrera, que si bien pertenecía al Modelo Sustitutivo de Importaciones continuaba con una lógica liberal positivista y verticalista (correspondiente al Modelo de Acumulación Agroexportador anterior).

Esta influencia del Modelo Tecnocrático Normativo se verifica en los planes FONAVI Y FEDERALES, a través de la planificación de la política habitacional centralizada con la aplicación de la racionalidad científica en las formas de producción y administración, departamentalización funcional, toma de decisiones por expertos y especialistas con parámetros de costo eficiencia que se orientan hacia soluciones prototípicas de producción masiva y economías de escala.

Así se vuelve imperioso instrumentar formas de participación de los destinatarios y sus organizaciones en la gestión y evaluaciones permanentes para realizar las correcciones y adecuaciones de los programas de viviendas, pero por sobre todo para conocer a las personas para quienes están destinados y saber lo que necesitan y sean ellos mismos los partícipes en el diseño de la vivienda y el barrio en que habitarán, evitando los análisis basados en racionalidades técnicas con intervenciones verticalistas.

En cuanto a su autarquía si bien se crea como organismo autárquico en 1956 depende hasta 1980 del Ministerio de Obras Públicas, y más tarde va perdiendo nuevamente de distintas formas su autarquía.

Así mismo se da la pérdida de funciones con la descentralización, como el abandono de muchas tareas técnicas, sociales, legales y administrativas que pasan a la órbita de los Municipios.

Por lo tanto no existe un registro de la demanda única con los déficit por partido (ya que no todos los municipios llevan este registro) para dar prioridades en la asignación 
de recursos, la cual puede terminar realizándose por tendencias electoralistas para conseguir el apoyo popular, y quedando marginada la población sin capacidad de pago.

Por su parte los programas no convocan la participación de las familias dándose una contradicción entre la formulación y la implementación de la política.

Además de la subejecución del presupuesto por decisión política del poder ejecutivo provincial, como así también la decisión de hacer pasar todo por la firma del ministro de infraestructura y también del ministerio de economía en relación al ingreso de los fondos en las cuentas bancarias.

Así, al IVBA, (dada la descentralización) le quedó su función financiera, pero necesitaría recuperar algunas funciones básicas, como conocer su demanda, realizar una planificación participativa y replantear los programas vigentes y futuros integrando otras políticas como las de trabajo, desarrollo, medio ambiente, salud y educación, con plazos de solución y la evaluación de lo realizado según las propias personas posibilitando su participación real.

De lo expuesto hasta aquí, se puede decir que la gestión del Instituto de la Vivienda de la Provincia de Buenos Aires en su Trayectoria Histórica se relaciona directamente con los modelos de acumulación económica de cada momento y la democracia, y da cuenta de una gestión de la Política Habitacional que posibilita avances o retrocesos en la efectivización del Derecho a la Vivienda según el momento de que se trate, visibilizándose una gran intervención y avance en los momentos centralizadores como el Plan FONAVI (que si bien se inicia en el '70 con el Estado Benefactor durante la Etapa Desarrollista del Modelo Sustitutivo de Importaciones adquiere su mayor desarrollo durante la Democracia desde 1983) y el Plan Federal iniciado en 2003 con el Modelo Aperturista en Transición al Productivo.

Destacándose dos lógicas distintas en torno a ellos, los FONAVI con grandes complejos habitacionales que no tienen un sentido explícito en términos de derechos pero constituyen un avance porque limitadamente reconocen el derecho contraído por la historia del grupo social en el lugar, y los FEDERALES con grandes barrios de viviendas individuales con posibilidades de ampliarse, con una perspectiva de derechos, de reactivación de la economía a través de la obra pública, la articulación con otras 
políticas sociales (como la formación de cooperativas de trabajo de población desocupada para la construcción de viviendas) y el fortalecimiento de los municipios (dado que la descentralización de los 90 les transfirió atribuciones pero no recursos ni económicos ni técnicos).

Así la trayectoria de la Gestión y Política Habitacional del IVBA, muestra hasta 1983, (tanto en el período de 1955 a 1976 del Modelo Sustitutivo de Importaciones en su Etapa Desarrollista, como en la Etapa Autoritaria de 1976 a 1983 del Modelo Aperturista) con la construcción de pocas viviendas (en relación al déficit habitacional) que el retroceso de la efectivización del derecho a la vivienda tiene que ver con la lejanía en la efectivización de la democracia (lo que también evidencia que algunas políticas persisten más allá de los recorte temporales).

Luego en el período Democrático de 1983 a 2009, en la Etapa de 1983 a 1992, respondiendo al Modelo Aperturista y la política habitacional centralizada, el IVBA construye una importante cantidad de viviendas en grandes conjuntos habitacionales produciendo un avance en la efectivización del derecho a la vivienda aunque aún sin incorporar el derecho a la ciudad.

En la Etapa de 1992 a 2003, en coincidencia con el modelo de acumulación Aperturista y la política neoliberal descentralizada y focalizada del momento, el IVBA reduce la producción de viviendas con lo cual se da un retroceso en la efectivización del derecho a la vivienda-ciudad.

Durante los últimos seis años, en el Período del Modelo Aperturista en Transición al Productivo, de 2003 a 2009, el IVBA muestra un gran ascenso en la efectivización del derecho a la vivienda, relacionado al modelo de acumulación económica productivo neoestadocéntrico y las políticas que intentan ser más universales del momento; con una construcción de gran cantidad de viviendas, aunque el derecho todavía es limitado dado por el reducido tamaño de las soluciones (si bien tienen posibilidades de ampliarse) como por la localización marginal y la carencia de infraestructuras propias de la ciudad.

Se puede verificar a través del análisis de la Trayectoria de la Política Habitacional en general y de la gestión del IVBA en particular (de 60 años) que los avances en la efectivización del derecho a la vivienda, se dan con el modelo de acumulación 
económica productivo- neoestadocéntrico, en democracia y cuando dicha Política se centra en el Estado, intenta ser universal y la inversión social se destina a los sectores populares, siendo reconocidos por las políticas como sujetos portadores de derechos.

Por el contrario, se dan retrocesos en dicha efectivización cuando la Política Habitacional se centra en el Mercado como asignador universal de recursos, la vivienda se mercantiliza primando su valor de cambio por sobre el de uso y el Estado se posiciona como facilitador de los procesos especulativos de dicho mercado (del suelo e inmobiliario especialmente) en favor de los sectores de altos ingresos; fenómeno que llegó a un agotamiento por lo cual se sancionó una nueva ley de hábitat para evitar estos mecanismos especulativos.

Tal es así que en la etapa de 1992 a 2003, la escasa inversión social se concentra en un reducido número de soluciones habitacionales desconociendo los derechos sociales de amplias capas de la población. Las pocas intervenciones, focalizadas en los sectores marginales desplazados del mercado, son organizadas por un Estado que lejos de planificar la resolución del déficit habitacional intenta contenerlo para evitar el estallido social.

Para finalizar, se está más cerca del derecho cuando la Política Habitacional es planificada y sostenida en el tiempo ya que tiende a garantizar la efectivización del derecho a la vivienda y a la ciudad (quedando pendiente aún este último), dependiendo de la necesidad de planes participativos para la construcción de viviendas, con variedad en las soluciones, adecuadas a la demanda diversificada de los sectores de menores recursos, con viviendas que se integren a la ciudad, y a la red de oportunidades que ésta ofrece como trabajo, salud, educación y transporte; para que los habitantes tengan la posibilidad de desarrollarse.

Además la complementación entre las Políticas Habitacionales y aquellas Políticas Sociales tendientes a lograr una más justa distribución del ingreso permiten una evolución social real, ya sea facilitando el acceso al crédito como también evitando la especulación en el precio de la tierra que la convierte en inaccesible para vastos sectores de la población. 
La "añoranza" de algunos integrantes del IVBA (surgido de las entrevista) de los tiempos donde existía un vínculo con las personas, donde se reconocía a los representantes del IVBA por su trabajo y se reconocían las personas para quienes trabajaban, recuerda las funciones perdidas por la descentralización. Esas personas a quienes suele perderse de vista son la razón de ser del IVBA, su fin social al que debe importarle justamente lo social, y trabajar para ello dando las soluciones que las personas necesitan según ellas mismas mediante su participación, porque en definitiva es su derecho a la vivienda lo que está en juego!

Para terminar, como dice Gastón Bachelard (2011) "Si se me pide que nombre el principal beneficio de la casa, debería decir: la casa alberga un día soñando, la casa protege al soñador, la casa le permite a uno soñar en paz." 


\section{ANEXO 1: ESTRUCTURA ORGANIZACIONAL DEL IVBA ${ }^{10}$}

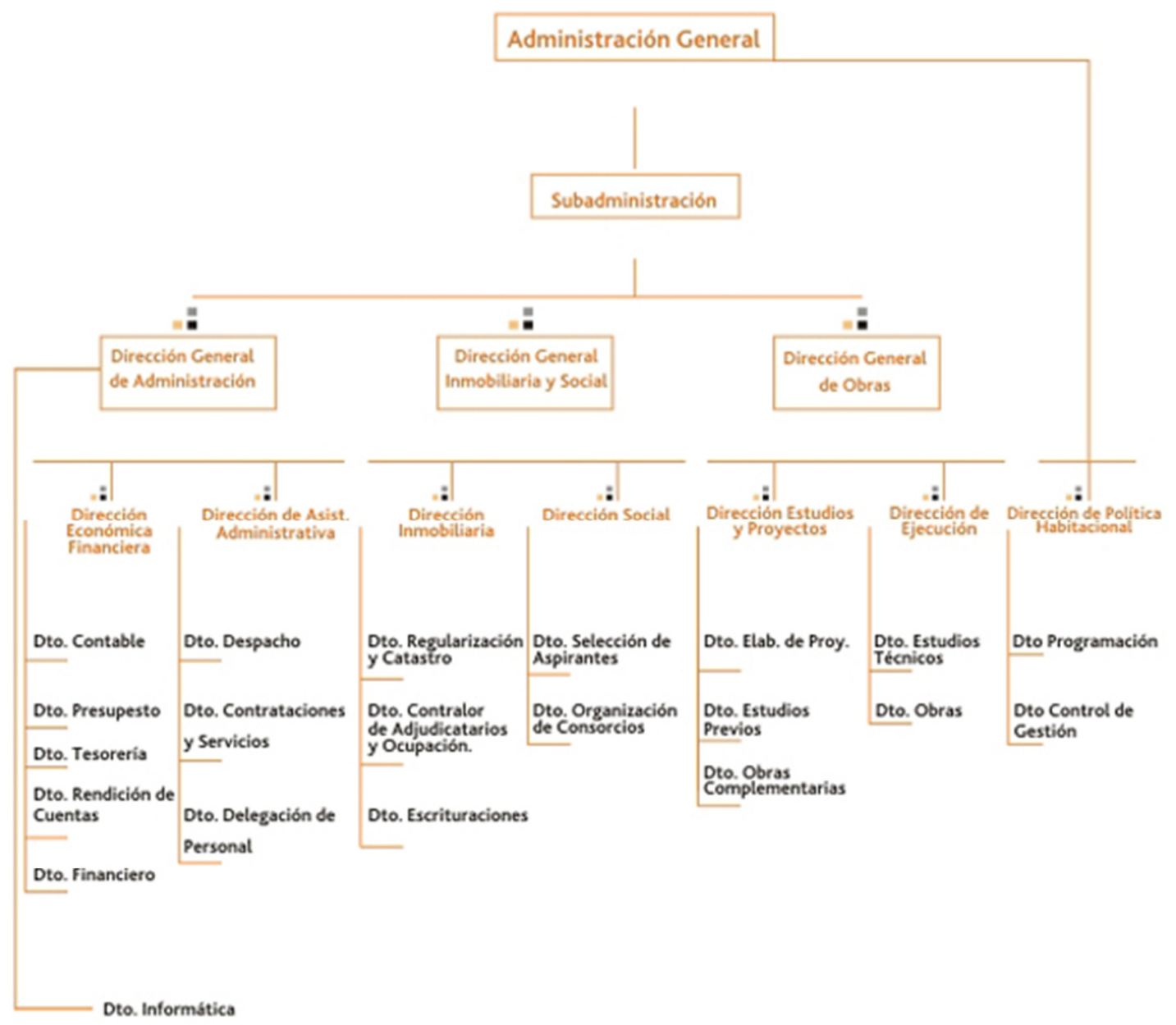

Leyes Provinciales

Constitución

Provincial

$\underline{\text { Ley } \mathrm{N}^{\circ} 9573}$

$\underline{\text { Ley } \mathrm{N}^{\circ} 6021}$

Ley $\quad \mathrm{N}^{\circ}$

$\underline{11663}$

$\underline{\text { Ley } 13.342}$

$\underline{\text { Decreto }}$
Sección 1: Declaraciones, Derechos y Garantías.

Artículo36: Derechos Sociales. Inciso 7: A la Vivienda.

Ley Orgánica del Instituto de la Vivienda.

Ley Provincial de Obras Públicas.

Adhesión al Sistema Federal de Vivienda (Ley 24464)

Operatoria para la regularización dominial.

Plan de Escrituración del Instituto de la

\footnotetext{
${ }^{10}$ Fuente: organigrama extraído de http://vivienda.mosp.gba.gov.ar
} 
Ley 13.059

Decreto

$\underline{1.030 / 10}$

Leyes Nacionales

Ley

$\underline{\mathrm{N}^{\circ}}$

21581

$\underline{\text { Ley }}$

$\underline{\mathrm{N}^{\circ}}$

23966

Ley

$\mathrm{N}^{\circ}$

24130

$\underline{\text { Ley }}$

$\underline{\mathrm{N}^{\circ}}$

24464

Ley

$\underline{\mathrm{N}^{\circ}}$

$\underline{25570}$

y

581

\section{y}

ey

임

Vivienda de Buenos Aires.

Acondicionamiento térmico en edificios de uso humano.

Condiciones de acondicionamientos térmico exigibles en la construcción de edificios. 
los recursos disponibles, satisfaciendo la creciente demanda habitacional a través de la articulación institucional con los Sectores públicos y privados.

El Decreto 1441 de 2003 del Poder Ejecutivo de la Provincia de Bs. As. firmado por el gobernador y los ministros de Infraestructura, de Economía y de Gobierno, aprueba en el ámbito del Ministerio de Infraestructura la siguiente estructura orgánica descentralizada de la Administración General del IVBA ${ }^{11}$ :

1 Administrador General

1 Subadministrador

3 Directores Generales

21 Jefes de Departamento

\section{OBJETIVOS:}

MINISTERIO DE INFRAESTRUCTURA, VIVIENDA Y SERVICIOS PÚBLICOS ADMINISTRACIÓN GENERAL DEL INSTITUTO DE LA VIVIENDA (I.V.B.A.)

1. Proponer y elaborar los proyectos necesarios para el desarrollo y aplicación de la política habitacional que establezca el Poder Ejecutivo Provincial.

2. Coordinar pautas, criterios y cursos de acción con organismos nacionales, provinciales y municipales, para dar cumplimiento a los planes habitacionales destinados al ámbito provincial.

3. Constituir el organismo de aplicación de las leyes nacionales y canalizar los recursos destinados al cumplimiento de los planes habitacionales en el ámbito de la Provincia de Buenos Aires.

4. Administrar los fondos de afectación, con sujeción a las normas legales vigentes y a los convenios suscriptos por la Provincia de Buenos Aires.

5. Realizar estudios y proyectos de los planes habitacionales que encaren la provincia y los municipios.

6. Suscribir convenios con organismos municipales, provinciales, nacionales e internacionales, personas o entidades públicas o privadas.

METAS DE LAS DIRECCIONES GENERALES

ADMINISTRACIÓN GENERAL DEL INSTITUTO DE LA VIVIENDA (I.V.B.A.) DIRECCIÓN GENERAL DE ADMINISTRACIÓN

${ }^{11}$ Información suministrada por Carlos Gardella, Subdirector de Asistencia Administrativa. 
1. Programar, controlar y supervisar los actos administrativos vinculados con la gestión contable, económica y financiera en el ámbito del Instituto. Elaborar el anteproyecto de presupuesto y controlar su ejecución.

2. Supervisar la fiscalización de la recaudación y administrar los créditos por la adjudicación de viviendas.

3. Organizar, controlar y gestionar los ingresos y egresos de fondos y valores del Instituto de acuerdo a las normativas vigentes.

4. Supervisar y controlar las acciones relacionadas con el registro de los bienes patrimoniales y con la organización y prestación de los servicios auxiliares necesarios para el buen funcionamiento del Instituto, como así también organizar, controlar y gestionar los actos vinculados a compras, actos licitatorios destinados a la contratación de obras que desarrolla el Instituto y liquidación de haberes5. Coordinar las actividades relacionadas con la administración de personal y el tratamiento y resolución de los temas laborales.

6. Organizar y prestar el apoyo técnico-administrativo necesario a las distintas dependencias del Instituto.

\section{DIRECCIÓN GENERAL DE OBRAS}

1. Proyectar y desarrollar las actividades inherentes a las obras que debe ejecutar el Instituto desde el proyecto hasta la recepción definitiva de las mismas, en las distintas operatorias en vigencia o a implementarse en el futuro.

2. Organizar, supervisar y controlar la ejecución de los proyectos asignados elaborar la documentación correspondiente.

3. Coordinar con los municipios, entes prestatarios, entidades intermedias y otros, las acciones que éstos deban cumplir por acción delegada.

4. Supervisar, coordinar y controlar la programación y ejecución de las distintas etapas de las obras, respetando los plazos y normativas impuestas.

\section{DIRECCION GENERAL INMOBILIARIA Y SOCIAL}

1. Planificar, evaluar, verificar y controlar los procedimientos de adjudicación, escrituración y conformación de consorcios en todas las viviendas y obras construidas y/o administradas por el Instituto, según las pautas vigentes para cada operatoria y organizar, coordinar e implementar las metodologías sobre las cuales se realizan dichos procedimientos. 
2. Coordinar acciones tendientes a organizar los consorcios en los conjuntos habitacionales que se construyan de acuerdo a la Ley de Propiedad Horizontal, en ejercicio preparatorio a la implementación de dicha ley.

3. Coordinar e implementar metodologías y sistemas de adjudicación de viviendas y organización de consorcios con los municipios que permitan la unificación y economía de esfuerzos, logrando eficiencia y celeridad en el accionar y proponer convenios para descentralización de los trabajos de adjudicación, organización de consorcios, control de ocupación, regularización y escrituración con los municipios.

4. Programar relevamientos sobre el estado ocupacional y financiero de las viviendas a fin de fiscalizar el cumplimento de las obligaciones asumidas por los adjudicatarios y promover la regularización de las situaciones anómalas que se verifiquen en las adjudicaciones y ocupaciones de efecto adjudicaciones, tenencias, depositarios $\mathrm{o}$ comodatarios que no cumplen con las normas establecidas en las documentaciones respectivas, leyes y resoluciones vigentes.

5. Ordenar y actualizar el Registro Único de Postulantes de Viviendas construidas y/o administradas por el Instituto y organizar y actualizar el Registro Único de Viviendas y Adjudicatarios en todos los complejos habitacionales construidos y/o administrados por el Organismo.

6. Organizar, promover e intervenir en la entrega de documentación a los adjudicatarios, de la documentación específica para la escrituración de viviendas, llevando registro por barrios de viviendas escrituradas, la inscripción dominial de las tierras donde se emplazarán conjuntos habitacionales y la incorporación al dominio del Instituto de todos los bienes que se transfieran o sean transferidos por éste.

\section{ACCIONES DE LAS DIRECCIONES}

\section{ADMINISTRACIÓN GENERAL DEL INSTITUTO DE LA VIVIENDA DIRECCION POLÍTICA HABITACÍONAL}

1. Elaborar, coordinar y difundir la política habitacional del Instituto, tomando como eje la planificación general, la evaluación de nuevas operatorias y/o solicitudes.

2. Desarrollar tareas de investigación, recolección y/o procesamiento de datos, estadísticos o no, referidos a la vivienda e infraestructura de servicios que den sustento científico-técnico a la planificación general.

3. Crear y consensuar con las otras Direcciones del Instituto, metodologías de evaluación que permitan determinar políticas de priorización y selección tanto de las nuevas operatorias como de las solicitudes a las ya vigentes. 
4. Verificar el desempeño del Instituto tomando como ejes el movimiento de expedientes, el seguimiento de las obras, el gasto, los recursos financieros y los medios humanos y materiales, como base del control de gestión.

5. Establecer y mantener vinculaciones con distintos organismos investigación, tecnológicos y de experimentación. A fin de realizar intercambios y estudios específicos en la materia, con la correspondiente revisión y recepción de documentación pertinente.

6. Proveer la información de gestión que requiera la Administración General y publicar periódicamente los resultados de las políticas aplicadas, avanzada las misiones explicitadas preferentemente.

\section{DIRECCIÓN GENERAL DE ADMINISTRACIÓN DIRECCIÓN DE ASISTENCIA ADMINISTRATIVA}

1. Desarrollar las acciones administrativas tendientes a brindar al Instituto de la Vivienda, el apoyo administrativo necesario y propiciar el análisis, elaboración y diligenciamiento de los actos resolutivos y dispositivos que se someten a consideración de las autoridades.

2. Coordinar y dirigir las actividades vinculadas con la administración de los recursos humanos asignados, de acuerdo a las normativas y elaborar el anteproyecto de presupuesto correspondiente.

3. Organizar, implementar y controlar el debido registro y protocolización de los actos administrativos, como así también, organizar y fiscalizar las tareas, ingreso, egreso y archivo de documentación, mantenimiento y actualización de archivos y bibliotecas técnicas, como asimismo el registro patrimonial de la jurisdicción.

4. Desarrollar las acciones necesarias para controlar y viabilizar las licitaciones públicas

o privadas destinadas a las contrataciones que realiza el Organismo.

5. Supervisar y coordinar la afectación, uso y conservación de vehículos oficiales. Recibir y controlar la entrega de vehículos y vales de combustible procedentes de empresas contratistas, según contratos.

6. Elaborar los pliegos de Licitaciones públicas o privadas destinadas a las distintas contrataciones que desarrolla el Instituto.

\section{DIRECCIÓN ECONÓMICO-FINANCIERA}

1. Elaborar el anteproyecto de Presupuesto Anual de la Repartición y controlar la ejecución presupuestaria correspondiente. 
2. Organizar, fiscalizar y administrar la recaudación originada por la adjudicación de viviendas y disposición de locales comerciales, de acuerdo con el régimen aplicable, atendiendo y controlando el reintegro de préstamos a municipios y/o entidades intermedias.

3. Atender los compromisos financieros del Organismo, disponiendo la liquidación y pago de remuneraciones y demás erogaciones operativas.

4. Centralizar las registraciones contables y rendir cuenta documentada ante los organismos de control.

5. Intervenir en todas las actuaciones que deriven en una transformación o variación de la Hacienda Pública.

6. Verificar el cumplimiento de los contratos de obra pública y préstamos sus aspectos presupuestarios, económicos y financieros.

\section{DIRECCIÓN GENERAL DE OBRAS}

\section{DIRECCIÓN ESTUDIOS Y PROYECTOS}

1. Encauzar la política y el plan de acción de los proyectos programados con las paulas del desarrollo provincial y municipal.

2. Evaluar y definir las necesidades de cooperación técnica, de programación y los aspectos normativos y metodológicos a considerar en la implementación de los planes, proyectos y programas del Instituto.

3. Asesorar, evaluar, supervisar y calificar a entidades públicas y privadas que propongan intervenir con el Instituto en la realización de soluciones habitacionales y analizar las documentaciones legales, dominiales, sociales y técnicas que presenten.

4. Coordinar e implementar mecanismo y sistemas de ordenamiento, y optimización y funcionalidad en el quehacer de los distintos sectores, tendiendo a la unificación y economía de esfuerzos y proponiendo la concertación y conciliación de pautas y criterios.

5. Asesorar sobre la confección de las normas de evaluación para la extensión del certificado de aptitud técnico de materiales, elementos y sistemas no tradicionales e implementar su aplicación.

\section{DIRECCIÓN EJECUCIÓN}

1. Fiscalizar, controlar, planificar y coordinar los contratos de obra pública que suscriba el Instituto en las distintas operatorias que estén en vigencia desde la firma del contrato hasta la recepción definitiva de la obra. 
2. Analizar, evaluar y aprobar la documentación de la obra definitiva que servirá para la ejecución de las distintas obras que se ejecutan a través del Instituto.

3. Analizar y aprobar todas aquellas modificaciones de obras que sean necesarias a efectos que la misma cumpla con la función para la que fue construida, tanto sean adicionales como economías.

4. Ejercer el control de todas las tareas que contractualmente deba realizar el contratista durante la ejecución de la obra observando todas aquellas metodologías técnicas y/o materiales utilizados que no correspondan a las especificaciones técnicas contractuales. Medir mensualmente las tareas realizadas de acuerdo al contrato y emitir el correspondiente certificado de obra y de mayores costos. Recibir las obras terminadas verificando el fiel cumplimiento de lodos los aspectos, de las condiciones y especificaciones fijadas por contrato a través de los respectivos pliegos, liberando, de este caso, las garantías constituidas por las empresas contratistas.

5. Coordinar con la Dirección de Estudios y Proyectos la formación de equipos de trabajo, integrados por agentes de ambas Direcciones, los que tendrán bajo su responsabilidad el análisis y control de toda documentación de proyecto realizado por terceros, como así también, de asesoramiento mutuo para aquellas documentaciones elaboradas por el Instituto.

6. Asesorar y asistir técnicamente a los municipios en aquellas obras que éste ejecute por delegación del Instituto de la Vivienda.

\section{DIRECCIÓN GENERAL INMOBILIARIA Y SOCIAL}

DIRECCIÓN INMOBILIARIA

1. Organizar, ordenar y actualizar el Registro Único de Adjudicatarios y Viviendas del Organismo.

2. Organizar la entrega de documentación escrituraria a los adjudicatarios de todos los conjuntos habitacionales y operatorias construidas, y/o administradas por el Instituto de la Vivienda de la Provincia de Buenos Aires.

3. Promover la escrituración o la inscripción dominial de las tierras donde se emplazarán conjuntos habitacionales.

4. Promover la regularización de las situaciones irregulares que se verifiquen en las adjudicaciones $\mathrm{u}$ ocupaciones de viviendas construidas y/o administradas por el Instituto de la Vivienda de la Provincia de Buenos Aires.

5. Promover los procedimientos administrativos tendientes a dejar sin efectos adjudicaciones, tenencias, depositarios o comodatos de adjudicatarios, tenedores, 
depositarios o comodatarios que no cumplan con las normas establecidas en la documentación respectiva, leyes y resoluciones vigentes.

6. Prestar colaboración, asesorar y brindar apoyo a las tareas de inscripción dominial y regularización a los municipios y/o entidades con las que se trabaje a partir de las operatorias descentralizadas.

\section{DIRECCIÓN SOCIAL}

1. Evaluar, verificar y controlar los procedimientos de adjudicaciones de viviendas construidas y/o administradas por el Instituto de la Vivienda de la Provincia de Buenos Aires según las pautas vigentes para cada operatoria.

2. Ordenar la organización de los consorcios en los conjuntos habitacionales se construyan de acuerdo a la Ley de Propiedad Horizontal.

3. Ordenar y actualizar el Registro y categorización de la demanda de viviendas construidas y/o administradas por el Instituto de la Vivienda de la Provincia de Buenos Aires.

4. Atender la coordinación e implementación de metodologías y sistemas de adjudicación de viviendas y creación de consorcios, y toda otra forma de organización comunitaria tendiente a fortalecer los vínculos de convivencia barrial, con los municipios y entidades intermedias que permitan la unificación y economía de esfuerzos, logrando eficacia y celeridad en las acciones.

5. Proponer a la Dirección General medidas tendientes a lograr un mejor accionar en las tareas del área.

6. Prestar colaboración, asesorar y brindar apoyo a los municipios y/o entidades con las que se trabaje a partir de las operatorias descentralizadas, en las tareas de su incumbencia.

7. Coordinar con la Dirección Inmobiliaria y demás áreas los planes, proyectos y programas necesarios a fin de lograr una mayor eficiencia técnico social.

\section{TAREAS DE LOS DEPARTAMENTOS}

ADMINISTRACIÓN GENERAL DEL INSTITUTO DE LA VIVIENDA

DIRECCIÓN DE POLÍTICA HABITACIONAL

DEPARTAMENTO CONTROL DE GESTIÓN

1. Producir los elementos de análisis que permitan a la Dirección efectuar el seguimiento y evaluación integral de las acciones del Instituto y la política en curso.

2. Evaluar el control interno del Instituto, en general y en particular de cada área. 
3. Informar y asesorar a la dirección respecto al desarrollo de las actividades de cada área del organismo, el correcto planeamiento de auditoría y la aplicación de adecuados programas de revisión.

4. Verificar la validez, propiedad y aplicación de los controles contables, patrimoniales, financieros y operativos, recomendar la aplicación de controles eficaces a un costo razonable.

5. Verificar, mediante controles generales y específicos, el funcionamiento de los sistemas de procesamiento de datos, debiendo disponer del acceso a los mismos para el cumplimiento de sus tareas.

6. Verificar la corrección de la información contable y financiera y de toda otra que se emita a los órganos operativos y de dirección, así como la elaboración del presupuesto del organismo y controlar su cumplimiento.

7. Elaborar métodos de evaluación y de control de gestión que permitan detectar las deficiencias, debilidades y desvíos producidos en el sistema contable-financiero del Instituto.

8. Verificar el grado de acatamiento a las políticas, planes, normas y procedimientos establecidos por medio de métodos que permitan apreciar su cumplimiento.

9. Efectuar el seguimiento de expedientes en general y de las obras desde su inicio hasta su finalización.

10. Organizar el seguimiento interno y externo de la documentación, en todas sus etapas de trámite, de las obras existentes, informando periódicamente del estado de situación a la Dirección.

\section{DEPARTAMENTO PROGRAMACIÓN}

1. Propender al desarrollo continuo de las soluciones habitacionales en correspondencia con las necesidades más críticas en función de los recursos de todo origen.

2. Elaborar metodologías de priorización y programación habitacional.

3. Registrar y evaluar las solicitudes presentadas a fin de emitir dictamen en base a datos demográficos del partido correspondiente y de los beneficiarios en particular de las soluciones a determinar.

4. Evaluar de acuerdo a operatorias existentes y cupos financieros, la factibilidad de localización y construcción de las soluciones habitacionales.

5. Elaborar la programación económico-financiera y de localización de conjuntos acorde con la política habitacional! propuesta. 
6. Elaborar y actualizar permanentemente los datos distritales referentes a redes de infraestructura de servicios y equipamiento, indicadores urbanísticos, tierras y todo otro dato necesario para la planificación de la localización de los conjuntos habitacionales.

7. Elaborar informes económicos y de encuadre legal presentados por el solicitante a fin de determinar su costo, financiación y posible inclusión dentro del presupuesto anual del Organismo.

8. Coordinar acciones con las áreas específicas de los municipios, entidades intermedias y organismos en general.

9. Elaborar informes relacionando la cobertura real y prevista con el déficit habitacional por partido y en correspondencia con las solicitudes presentadas a los fines de orientar la elaboración de nuevos convenios o de detectar posibles desviaciones con respecto a la política habitacional propuesta.

10. Detectar la correlación de avance físico y financiero de las obras en ejecución a efectos de calificar la capacidad operativa de los municipios y entidades intermedias responsables de la concreción de los conjuntos habitacionales.

\section{DIRECCIÓN GENERAL DE ADMINISTRACIÓN}

DEPARTAMENTO INFORMÁTICA

1. Definir e impulsar el Plan Integral de Informática para todo el Organismo.

2. Definir el Presupuesto Anual referido al área Informática.

3. Supervisar todo tipo de actividades referidas a la informática que se realice dentro del ámbito del Instituto.

4. Intervenir en las compras y/o contrataciones referidas a recursos informáticos para todo el Organismo.

5. Asesorar a municipios y/o a entidades intermedias sobre sistemas computarizados referidos a la problemática de viviendas.

6. Definir los métodos administrativos necesarios, para garantizar la continuidad operativa de los sistemas computarizados.

7. Definir y controlar los sistemas de seguridad para salvaguardar las bases de datos.

8. Desarrollar e implementar sistemas, realizando las tareas necesarias de acuerdo a las metodologías utilizadas.

9. Realizar la grabación de datos necesarios para asegurar la explotación de los sistemas. 
10. Definir las especificaciones técnicas globales sobre hardware y software, e impulsar las medidas necesarios que aseguren su continuidad operativa.

\section{DIRECCIÓN DE ASISTENCIA ADMINISTRATIVA}

\section{DEPARTAMENTO PERSONAL}

1. Administrar las relaciones de trabajo y la carrera administrativa de los agentes de la Administración - Instituto de la Vivienda -, con sujeción a las normas que regulan el régimen para el personal de la Administración Pública-Provincial. 2. Estudiar, interpretar y aplicar las normas legales vigentes, establecidas en el Estatuto para la Administración Pública Provincial. Llevar registro de sumarios administrativos.

3. Ejecutar todas las tareas referentes al régimen horario, asistencia, licencias y obligaciones concordantes de personal para la aplicación de las normas específicas existentes en los estatutos vigentes.

4. Recopilar y registrar los antecedentes personales y de la carrera de todo agente del Organismo en sus respectivos legajos. Llevar registro de sumarios ordinarios. Aportar los antecedentes necesarios para la formulación del anteproyecto anual, en materia de personal y cargas sociales.

5. Brindar el apoyo a las distintas unidades jerárquicas de la Repartición en materia de personal.

6. Emitir órdenes de pasajes oficiales y su control posterior.

7. Analizar y elaborar los actos administrativos que se someten a la rúbrica de las autoridades del Organismo.

8. Supervisar la confección de órdenes y pago de haberes, viáticos, movilidad, horas suplementarias de labor, reajustes, bloqueo de título, bonificaciones y de certificados codificados de servicios.

\section{DEPARTAMENTO DESPACHO}

1. Recibir la totalidad de las actuaciones provenientes de las distintas áreas del Organismo y/o del exterior.

2. Ejecutar las actividades inherentes a la elaboración, análisis y diligenciamiento de los actos resolutivos y dispositivos que se someten a la consideración y rúbrica de las autoridades del Organismo, y elaborar anteproyectos de decretos y resoluciones que corresponden someterse a la consideración y rúbrica de las autoridades ministeriales 
3. Atender el despacho de las actuaciones administrativas, cualquiera fuere su temática, con arreglo a los circuitos administrativos emergentes de la estructura orgánico funcional del Instituto.

4. Analizar, orientar y registrar la tramitación de expedientes, notas, memorandos, oficios judiciales y demás actuaciones originadas en el organismo o dirigidas a él.

5. Supervisar y coordinar la registración, recopilación, comunicación y publicación de los actos resolutivos emanados de las autoridades del Organismo, manteniendo actualizado el digesto de resoluciones y disposiciones.

6. Analizar, elaborar y gestionar la rúbrica de proveídos de respuesta a juzgados, sedes policiales, Corte Suprema de Justicia, Fiscalía de Estado; así como las cédulas de intimación de pago en los casos de embargos preventivos, con simultánea contestación a los juzgados intervinientes.

7. Atender la registración computarizada, por índice temático y número de actos administrativos emanados del Organismo y pedidos de informes provenientes de sedes policiales $\mathrm{y} / \mathrm{u}$ oficios judiciales, en los cuales el Organismo resulta parte actora o demandada, ejercitando el control de gestión de los plazos procedimentales correspondientes.

\section{DEPARTAMENTO CONTRATACIONES Y SERVICIOS}

1. Coordinar, ordenar y supervisar los sistemas previstos en el ordenamiento legal para la contratación de bienes, útiles, enseres, etc. En todo de acuerdo con las disposiciones contenidas en la Ley de Contabilidad y de Obras Públicas.

2. Cumplimentar los distintos actos licitatorios para las contrataciones de obras, mediante la Ley de Obras Públicas de la Provincia de Buenos Aires y Ley de Contabilidad, conformando la Comisión de Pre adjudicación.

3. Recibir, controlar y conformar las facturas que ingresan al Organismo y supervisar el cumplimiento de los proveedores.

4. Acopiar y distribuir los útiles y/o elementos adquiridos por el Organismo para abastecer las necesidades de los sectores.

5. Mantener el funcionamiento del sector fotocopia e impresiones menores encauzando la provisión del material necesario en tiempo y forma, como así también el mantenimiento de las máquinas a través de la Empresa a cargo de las mismas.

6. Recibir, según contrato, vehículos y vales de combustible provenientes de las empresas y su distribución, controlando el cumplimiento de todas las obligaciones emergentes de los contrato de obra. 
7. Mantener actualizado el registro de entradas y salidas de materiales a través de responsables del Registro Patrimonial de Segundo Orden.

8. Cumplir y hacer cumplir todas las disposiciones legales vigentes para choferes de vehículos oficiales y/o funcionarios a cargo del mismo, su registración en los libros pertinentes y asentamiento en el legajo personal de cada uno de ellos.

\section{DIRECCIÓN ECONÓMICO FINANCIERA DEPARTAMENTO CONTABLE}

1. Disponer las registraciones contables de los recursos y gastos con arreglo a las normas legales vigentes.

2. Intervenir en la gestión de pago de las remuneraciones de cualquier naturaleza, previo análisis del estado de fondos de las cuentas intervinientes.

3. Asegurar a través de registraciones diarias una información eficiente del estado de las distintas contabilidades.

4. Disponer las transferencias de fondos y la aplicación de fondos financieros que aseguren financiamiento.

5. Confeccionar de acuerdo a las normas vigentes de la Contaduría General de la Provincia, las planillas que la misma demande, asegurando su conciliación con el resto de las contabilidades.

6. Confeccionar los balances mensuales y de fin de ejercicio.

7. Aportar antecedentes para la confección del anteproyecto de Presupuesto y para la confección del expediente de cierre de cada ejercicio.

8. Registrar la Contabilidad de Explotación que permite conocer el estado patrimonial ajustado a inventario y estado de resultados.

9. Centralizar el registro general y archivo de las órdenes de pago que se emitan, mediante libro rubricado y cargar por sistema computarizado de órdenes de pago, con pago-efectivizado. Registrar y archivar las órdenes de compra, resoluciones y disposiciones y los triplicados de las facturas de compra.

\section{DEPARTAMENTO CONTABLE}

1. Responder en forma solidaria e indelegable por el manejo de los fondos y valores sometidos a su administración.

2. Efectivizar los pagos con arreglo a libramientos de órdenes de pago correspondientes a contratistas, proveedores y personal del Organismo. 
3. Recibir y mantener actualizado el Registro de Poderes, Cesiones, Embargos y Prendas.

4. Ejecutar los depósitos por retenciones de sueldo, retenciones de contratistas y retenciones varias.

5. Llevar registro analítico de fianzas, garantías u otros valores y atender su custodia.

6. Registrar el movimiento diario de las distintas cuentas corrientes bancarias del organismo.

7. Controlar los movimientos que se operan en las cuentas corrientes fiscales registradas a la orden del Instituto.

8. Denunciar movimientos diarios de ingresos y egresos de fondos y valores para su registración contable.

9. Conciliar los movimientos diarios con resúmenes bancarios y con partes de movimientos de fondos.

10. Analizar y verificar para dar respuesta a las observaciones del Honorable Tribunal de Cuentas e instrumentar el pedido de fondos a la Contaduría General de la Provincia y Tesorería General de la Provincia.

\section{DEPARTAMENTO RENDICIÓN DE CUENTAS}

1. Formular la Contabilidad de responsables.

2. Controlar los legajos para su presentación a la Contaduría General de la Provincia, quien lo eleva al Honorable Tribunal de Cuentas.

3. Controlar la contabilidad de cargos y descargos y conciliar con las contabilidades de movimiento de fondos y presupuesto.

4. Rendir cuenta documentada de los recursos y erogaciones ante los Organismos de Control.

5. Conciliar y registrar en forma computarizada los pagos presupuestarios, residuos pasivos y cuenta de terceros.

6. Controlar el curso de los expedientes una vez efectuada la rendición.

7. Controlar la emisión en tiempo y forma del balance mensual.

8. Registrar las rendiciones de cuentas por Partida Principal

9. Confeccionar legajos con su correspondiente planilla y carátulas de cada partida y elaborar planillas demostrativas del estado de las mismas. 


\section{DEPARTAMENTO PRESUPUESTO}

1. Disponer la apertura de créditos presupuestarios, transferencias de partidas, ampliaciones y reducciones y registrar los mismos.

2. Intervenir en la afectación provisoria del gasto ejerciendo el control sobre los saldos de las mismas, confeccionando las minutas de compromisos provisorios correspondientes.

3. Elaborar el Anteproyecto de Presupuesto Anual del Ejercicio.

4. Desarrollar la ejecución presupuestaria con arreglo a las técnicas que aseguren una información rápida y eficiente.

5. Observar, todos los actos que se impulsen señalando las disposiciones legales de cumplimiento obligatorio.

6. Elevar mensualmente a la Contaduría General de la Provincia la información requerida por ese organismo, con arreglo a las disposiciones que la misma emita.

7. informar sobre el estado de deudas, intereses, adicionales, economías daños u otros conceptos que tengan que ver con el desarrollo de los contratos de obras.

8. Determinar, analizar, controlar y conciliar con contabilidades de movimientos de fondos, balances mensuales y anuales.

9. Confeccionar el balance de cierre del ejercicio y el respectivo expediente.

\section{DEPARTAMENTO FINANCIERO}

1. Asesorar a los adjudicatarios, entidades intermedias y Municipalidades respecto de los pasos a seguir para el pago de las cuotas de amortización.

2. Promover las recaudaciones por el pago de cuotas, ya sea en forma directa o mediante depósito o pago por Tesorería.

3. Controlar el registro de altas y bajas y modificaciones en la adjudicación de viviendas, sea por renuncias individuales, corrección de nombres y/o apellidos, cambio de domicilio, etc., dando los códigos reservados a tal efecto.

4. Preparar y enviar al Departamento Informática los datos para la actualización del padrón.

5. Emitir chequeras y/o certificados para cobranza a municipalidades y entidades intermedias, y determinar y actualizar el precio de los locales comerciales, fijar el plan de financiación y comunicar al Departamento Informática, al igual que para los equipamientos comunitarios.

6. Confeccionar minutas para escrituración de viviendas. 
7. Confeccionar los certificados de cancelación de deudas verificando el correcto importe de las cuotas y la totalidad de la impresión.

8. Preparar expedientes para las licitaciones y/o remates de locales comerciales.

9. Intervenir en las aperturas de licitaciones de locales comerciales, preparar boletos de compraventa y gestionar su firma, redactar actas de tenencias precarias, comodatos, depositarios, etc.

10. Redactar convenios de transferencias de equipamientos comunitarios.

\section{DIRECCIÓN GENERAL DE OBRAS}

\section{DIRECCIÓN ESTUDIOS Y PROYECTOS}

\section{DEPARTAMENTO PROYECTOS}

1. Brindar asesoramiento y supervisión concerniente a su área, a municipalidades, entidades intermedias, y/o empresas para ejecución de soluciones habitacionales encuadradas en los programas vigentes.

2. Elaborar los programas de los prototipos que respondan a tipologías funcionales zonales, acorde a las normas vigentes municipales, provinciales y nacionales.

3. Aplicar las normas fijadas por el Instituto para el otorgamiento de Certificados de aptitud técnica de materiales, elementos y sistemas constructivos no tradicionales, (C.A.T.I.V.B.A.).

4. Implementar el relevamiento, análisis y seguimiento de los sistemas constructivos no tradicionales en el ámbito de la provincia.

5. Supervisar la revisión y aprobación de los proyectos de obra del Organismo.

6. Proyectar conjuntos habitacionales y sus correspondientes prototipos compatibilizando normas y leyes. Elaborar memorias descriptivas y especificaciones técnicas de los mismos.

\section{DEPARTAMENTO ESTUDIOS PREVIOS}

1. Brindar asesoramiento y supervisión técnico-legal concerniente a su área, a municipios, entidades intermedias y/o empresas para la ejecución de soluciones habitacionales encuadradas en los programas vigentes.

2. Tramitar y/o gestionar hasta su aprobación, ante los organismos pertinentes, las documentaciones generadas en el área. 
3. Efectuar los estudios sobre documentación legal relacionada con la asistencia jurídica dominial y transferencia de tierras comprometidas por las entidades intermedias.

4. Informar oficios y requerimientos de naturaleza jurídica dentro de su competencia.

5. Evaluar los terrenos propuestos para determinar la aptitud, viabilidad y/o desestimación de los mismos.

6. Proponer a través de relevamientos socio-físicos la solución adecuada a cada localización.

7. Realizar los estudios, tendientes a determinar la evaluación y situación dominial de terrenos propuestos.

\section{DEPARTAMENTO OBRAS COMPLEMENTARIAS}

1. Brindar asesoramiento y supervisión concerniente a su área, a municipios, entidades intermedias $\mathrm{y} / \mathrm{o}$ empresas encuadradas en los programas vigentes.

2. Elaborar los proyectos de infraestructura en los conjuntos urbanos proyectados por el Instituto, compatible con las normas vigentes.

3. Realizar y verificar cálculos estructurales de las obras del Instituto.

4- Revisar y aprobar los proyectos y cálculos estructurales realizados por otras entidades.

5. Tramitar y/o gestionar hasta su aprobación ante los organismos pertinentes, La documentación generada en el área.

6. Evaluar, analizar y recopilar información sobre terrenos fiscales aptos para la localización de viviendas.

\section{DIRECCIÓN EJECUCIÓN}

\section{DEPARTAMENTO ESTUDIOS TÉCNICOS}

1. Cumplir con las directivas emanadas de la superioridad interpretando y transmitiendo a las áreas a su cargo, el orden de prioridades de dichas directivas. Mantener informada a la Dirección de Ejecución de las novedades que surjan de los temas inherentes al departamento.

2. Realizar todas las gestiones necesarias para la realización de los certificados y pago de adelantos financieros de todas las obras, que ejecuta la Dirección de Ejecución, elevando dichos certificados a las áreas correspondientes para su pago.

3. Recopilar datos estadísticos periódicos, que permitan determinar la magnitud actualizada de lo producido, representando de esta manera las líneas de 
tendencia además que permitan realizar las previsiones y proyecciones sobre el área de trabajo que le compete, obteniendo así la idea concreta de la realidad de los tiempos inmediatos y mediatos, pudiendo extraer de esta manera, conclusiones acerca de las prioridades.

4. Efectuar el control de gestión de los diversos trámites internos y externos de área. Evaluar los tiempos utilizados e implementar asimismo las medidas correctivas necesarias para optimizar los mismos.

5. Realizar el control técnico y administrativo de los sectores a su cargo. Elevar a la Dirección de Ejecución los hechos concretos, sugiriendo su tratamiento, con los agregados y alternativas necesarias que permitan a la Dirección la clarificación de los temas, facilitando de esta manera una pronta toma de decisión de los mismos.

6. Mantener actualizados los archivos de documentación que para cada caso se implemente y realizar todos los programas necesarios para tener un seguimiento completo de cada obra, desde su inicio en el Departamento Estudios Previos hasta su finalización con la recepción definitiva de la obra.

7. Actualizar permanentemente la información y realizar el correspondiente relevamiento en cada área de las distintas direcciones, con la periodicidad que es menester para el seguimiento de las obras y adecuar y/o reformular las obras que así lo requieran ante cambios en la normativa vigente, en cuanto a los valores financiables.

8. Contestar requerimientos de organismos nacionales y asesorar a las municipalidades y entidades intermedias en la confección de planes de trabajo y curvas de inversión.

9. Contestar los requerimientos de organismo provinciales.

10. Adecuar y/o reformular las obras que así lo requieran ante cambios en la normativa vigente en cuanto a los valores financiables.

\section{DEPARTAMENTO OBRAS}

1. Coordinar y supervisar los sectores a su cargo en Sede - Área Norte, Centro y Sur, e Inspector de Obras y Delegaciones Bahía Blanca y Mar del Plata.

2. Visar y aprobar la documentación técnica presentada por las empresas contratistas, entidades intermedias y municipios.

3. Visar y aprobar los planes de trabajos de las obras en ejecución o contratadas.

4. Efectuar el seguimiento e inspección de las obras en ejecución, de acuerdo con las normativas contractuales o pautas de convenio, según corresponda. 
5. Ordenar las inspecciones extraordinarias a obra por parte del personal técnico de apoyo a su cargo, cuando circunstancias particulares u órdenes superiores así lo impongan.

6. Realizar las mediciones periódicas de las obras.

7. Realizar estudios técnico-económicos que surjan como encomiendas de la Dirección de Ejecución.

8. Asesorar a municipios y entidades intermedias en la confección de planes de trabajos y curvas de inversión.

9. Informar a la Dirección de Ejecución respecto de modificaciones de obra y cualquier otra circunstancia que pueda alterar las condiciones contractuales, sugiriendo alternativas de orden técnico para facilitar a ésta la toma de decisiones.

10. Mantener actualizado los archivos de documentación que para cada obra se implemente.

DIRECCIÓN GENERAL INMOBILIARIA Y SOCIAL DIRECCIÓN INMOBILIARIA

DEPARTAMENTO REGULARIZACION Y CATASTRO

1. Organizar, ordenar y actualizar el Registro Único de Viviendas y Adjudicatarios.

2. Controlar la suscripción de la documentación por parte de los adjudicatarios en los barrios en las entregas de unidades habitacionales.

3. Evaluar las situaciones pendientes de adjudicación por patrimonio declarado o impugnaciones y denuncias, aconsejando su calificación o descalificación.

4. Organizar, ordenar y evaluar los pedidos de cuidadores de viviendas construidas y/o administradas por el Instituto, llevando un registro de los mismos.

5. Evaluar los pedidos de cambio de titularidad, permutas solicitadas por adjudicatarios de las viviendas construidas y/o administradas por el Instituto, propiciando o no su aprobación.

6. Verificar el estado ocupacional de unidades habitacionales construidas y/o administrados por el Instituto, con el fin de regularizar la documentación pertinente.

\section{DEPARTAMENTO CONTRALOR DE ADJUDICATARIOS Y OCUPACIÓN}

1. Verificar de oficio o por denuncias realizadas, las ocupaciones de unidades habitacionales que se encuentren desocupadas, alquiladas, cedidas y/o vendidas. 
2. Impulsar los trámites legales para dejar sin efectos adjudicaciones de viviendas cuyos adjudicatarios no cumplan con las normas vigentes.

3. Impulsar los procedimientos de desalojo de unidades habitacionales que se ocupen por intrusos.

4. Promover la regularización de viviendas ocupadas en forma irregular por grupos familiares.

5. Propiciar las bajas de adjudicatarios que hayan sido desafectados de viviendas construidas y/o administradas por el Organismo.

\section{DEPARTAMENTO ESCRITURACIONES}

1. Realizar censos ocupacionales en las viviendas construidas y/o administradas por el Instituto, en carácter previo a la escrituración de las mismas.

2. Estudiar y proponer Reglamentos de Copropiedad, y Administración propiciando la intervención de la Escribanía General de Gobierno.

3. Proyectar actos administrativos de escrituración.

4. Llevar registros de viviendas y adjudicatarios en barrios escriturados.

5. Promover la extensión de escrituras de cancelación hipotecaria, requiriendo la información correspondiente.

6. Intervenir en todo trámite de escrituración de bienes -que se incorporen al Instituto o sean transferidos por éste y verificar y corroborar la documentación técnica de los conjuntos habitacionales en condiciones de Escriturar.

7. Realizar inventarios de viviendas y/o locales comerciales correspondientes a cada conjunto habitacional.

8. Proponer convenios con empresas de servicios públicos para la constitución de servidumbres de núcleos habitacionales en condiciones de escriturar.

9. Elaborar los informes para la incorporación de tierras al patrimonio del Organismo y transferencia de remanente a otros organismos públicos y/o privados para la transferencia de tierras.

10. Asesorar a municipios y/o entidades intermedias en la preparación de documentación necesaria para la transferencia de tierras a este Organismo.

\section{DIRECCION SOCIAL}

\section{DEPARTAMENTO SELECCIÓN DE ASPIRANTES}

1. Organizar la adjudicación de viviendas de acuerdo a las normas vigentes para cada operatoria. 
2. Organizar y actualizar el Registro Único de Postulantes de Viviendas.

3. Asesorar y supervisar técnicamente a los municipios, entidades intermedias y Organismos intervinientes en el proceso de selección de adjudicatarios de acuerdo a cada operatoria.

4. Analizar los aspectos socio-económicos de los aspirantes a viviendas y clasificar, de acuerdo al grado de necesidad, los pedidos de vivienda realizados por los grupos familiares.

5. Realizar verificaciones domiciliarias a los postulantes de viviendas, a fin de verificar su situación habitacional y familiar.

6. Promover la adjudicación de los postulantes para las viviendas, de acuerdo a cada operatoria y a las normas vigentes.

7. Organizar y ordenar toda la documentación que ingresa al Departamento elaborando los informes requeridos por otras áreas del Instituto y proponer archivo de la misma, una vez producida la adjudicación de la vivienda y de los complejos habitacionales construidos y/o administrados por el Instituto.

\section{DEPARTAMENTO ORGANIZACIÓN DE CONSORCIOS}

1. Propiciar y promover la organización de los consorcios de los conjuntos construidos y/o administrados por el Instituto y asesorar técnicamente a los municipios para la formación de los consorcios y su posterior control.

2. Supervisar y controlar el cumplimiento de los adjudicatarios de las obligaciones con respecto al consorcio y comisiones administradoras.

3. Realizar auditorías de comisiones administradoras informando su resultado a los adjudicatarios y promover los procedimientos administrativos que correspondan.

4. Orientar a los usuarios en sus cualidades de integrantes de los grupos de copropietarios.

5. Organizar, controlar y supervisar la información requerida por las áreas del Organismo, en los temas de su incumbencia. 
ANEXO 2: FOTOS

Operatorias del IVBA $(1956-1976)^{12}$

Barrios Obreros

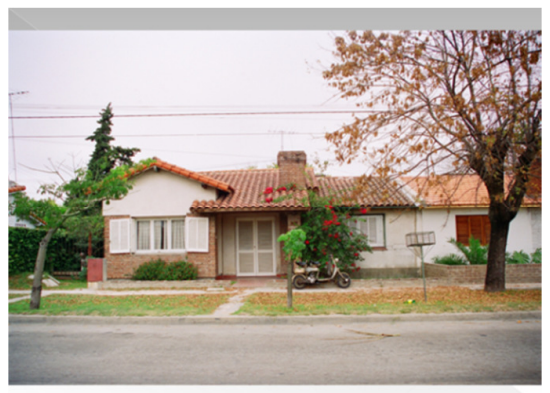

Provincia y Municipio (PYM)

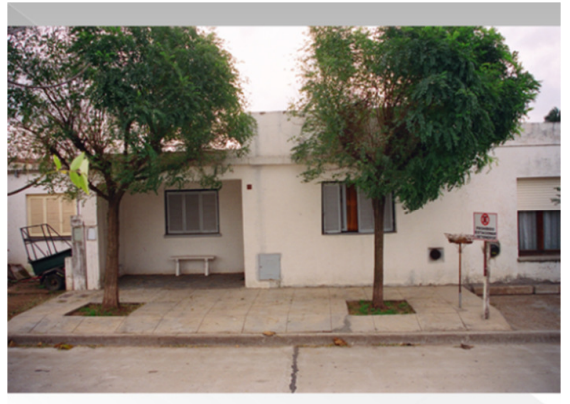

ATEPAM
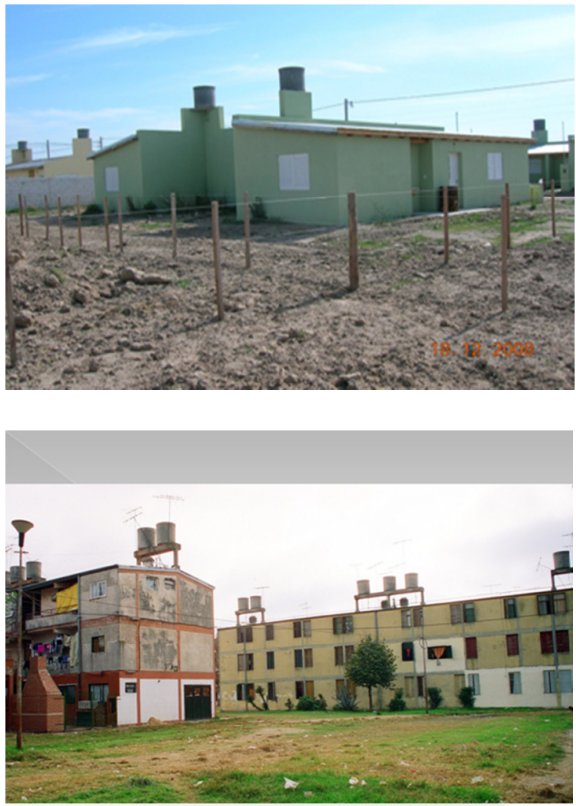

Barrios Arquitectura

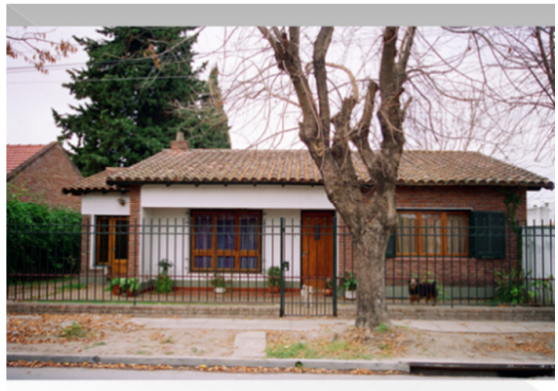

Entidades Intermedias

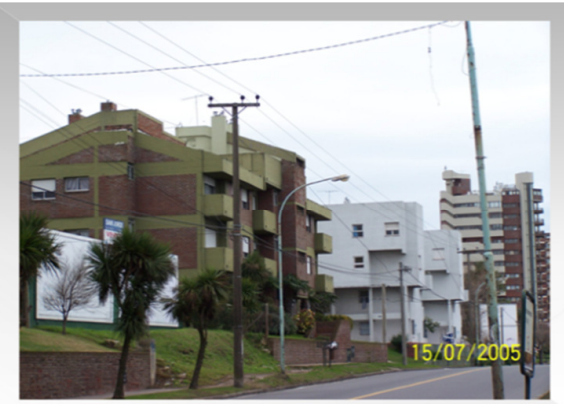

PEVEP

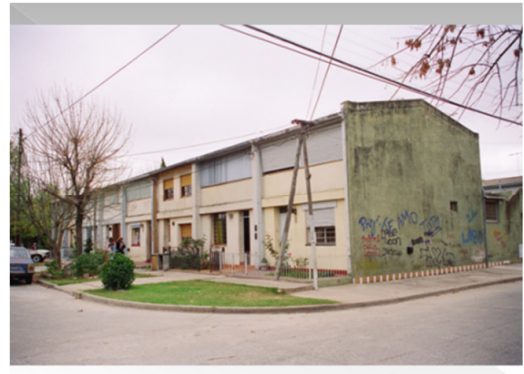

${ }^{12}$ Fotos pertenecientes a la Dirección de Política Habitacional del IVBA. 
Operatorias del IVBA $(1976-1983){ }^{13}$

FONAVI

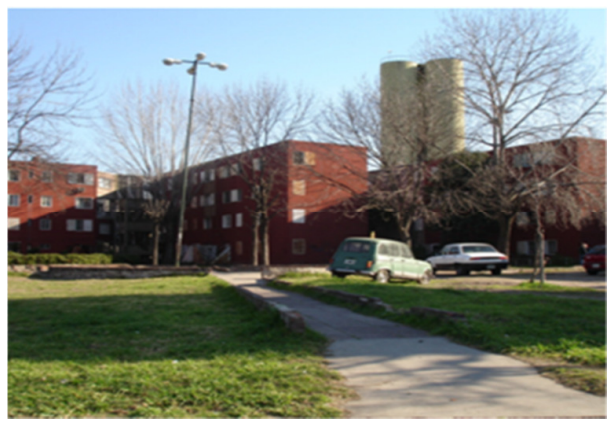

ALBORADA

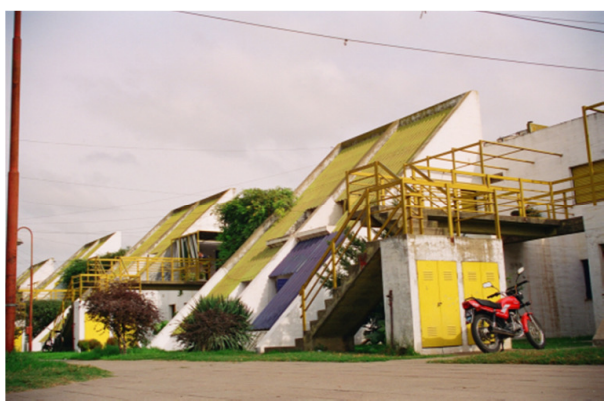

Operatorias del IVBA (1983-1992)

Coparticipación Autogestión
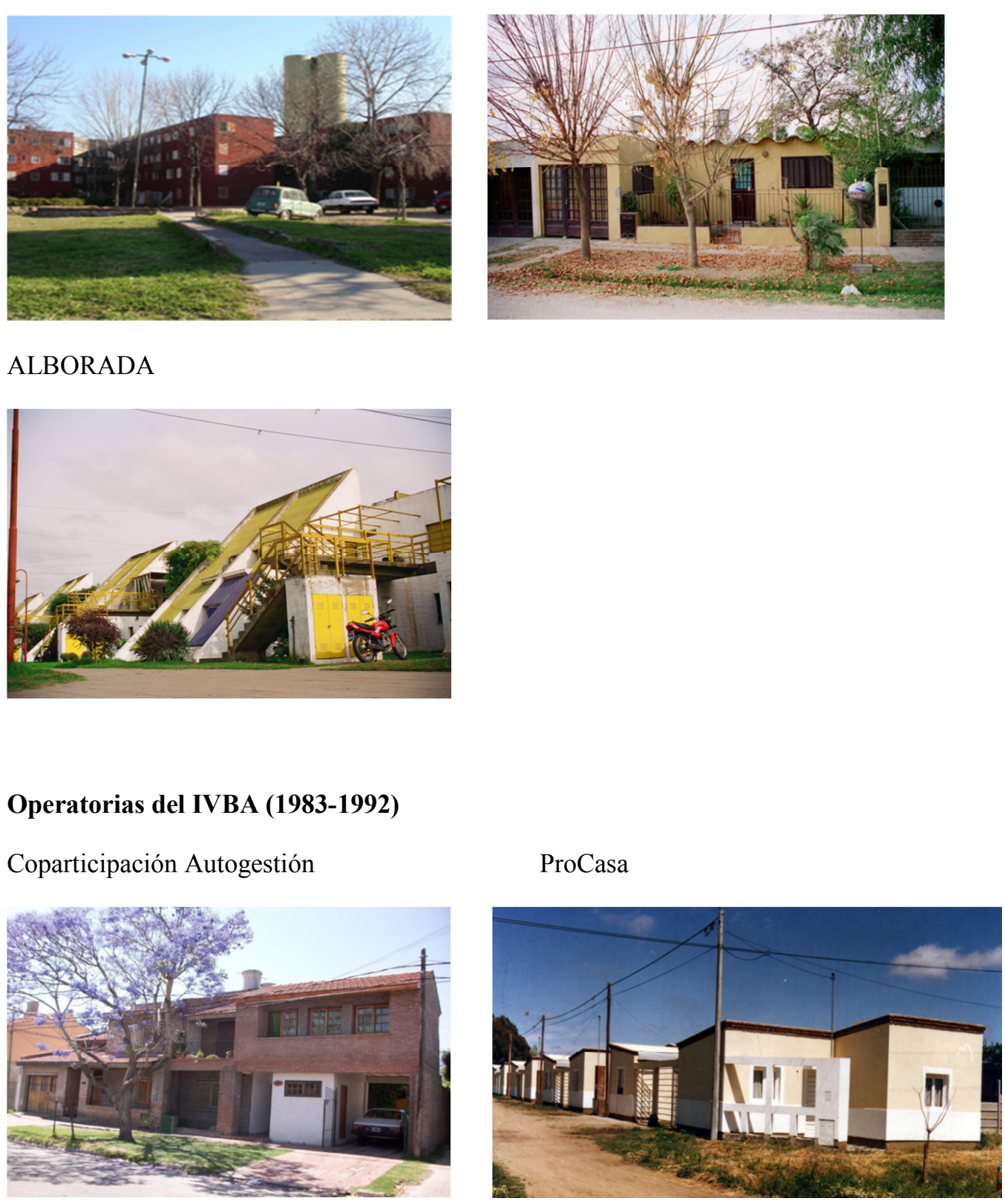

FOPROVI

Vuelta al Pago

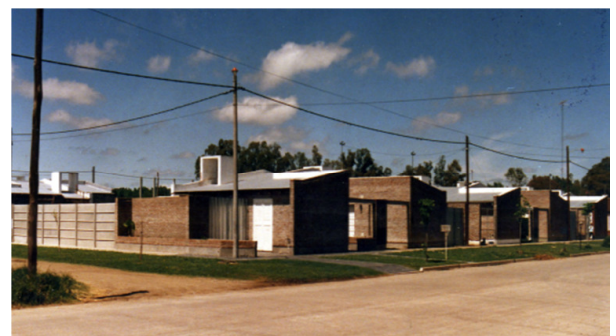


Operatorias del IVBA $(1992-2003){ }^{14}$

Bonaerense I

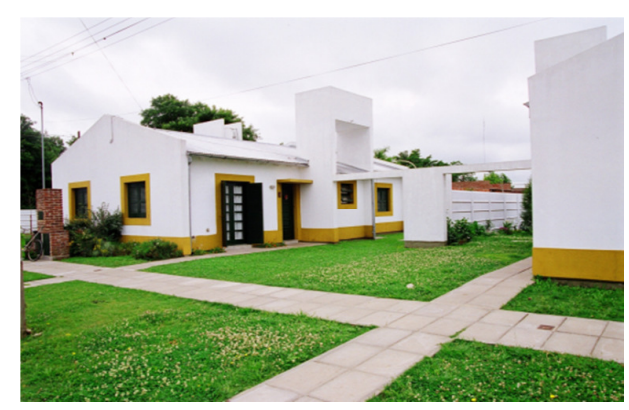

Bonaerense II

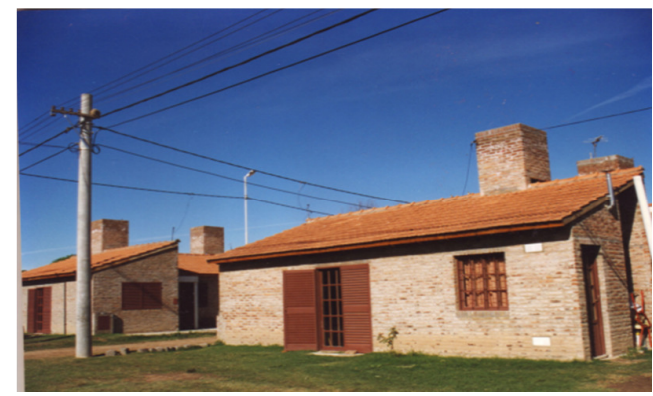

Bonaerense III

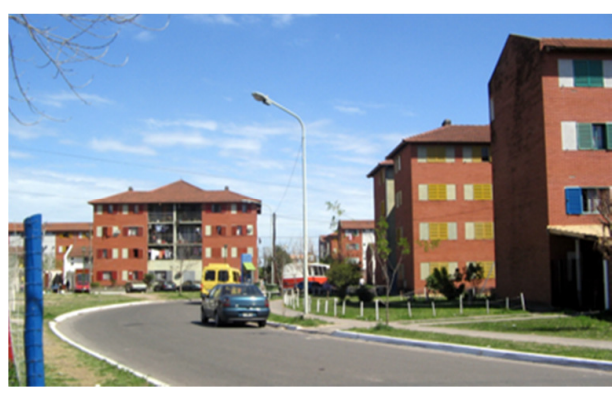

${ }^{14}$ Fotos pertenecientes a la Dirección de Política Habitacional del IVBA. 
Operatorias del IVBA $(2003-2009){ }^{15}$
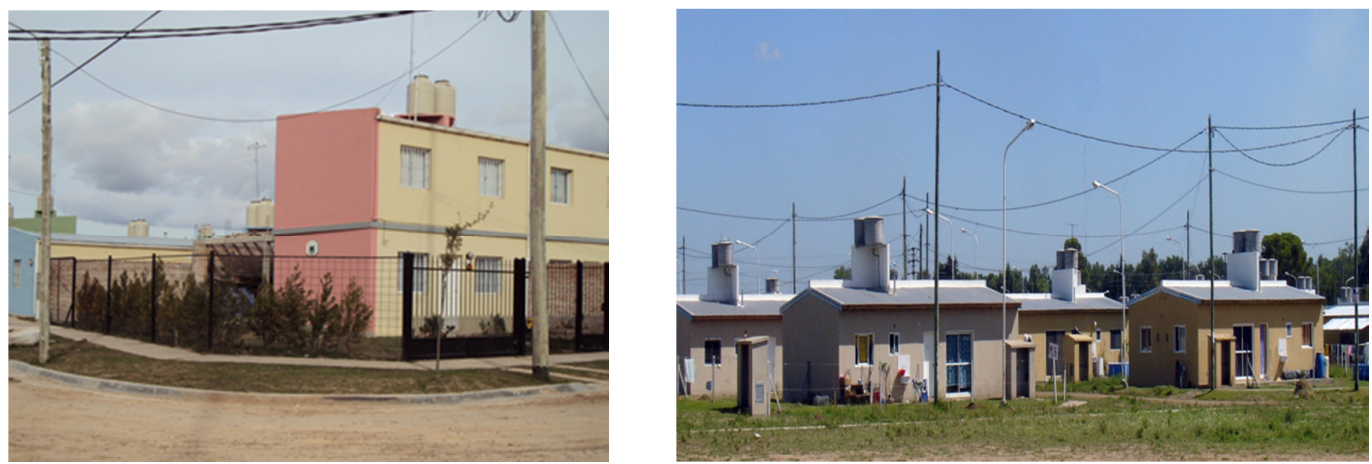

Federal con Municipios
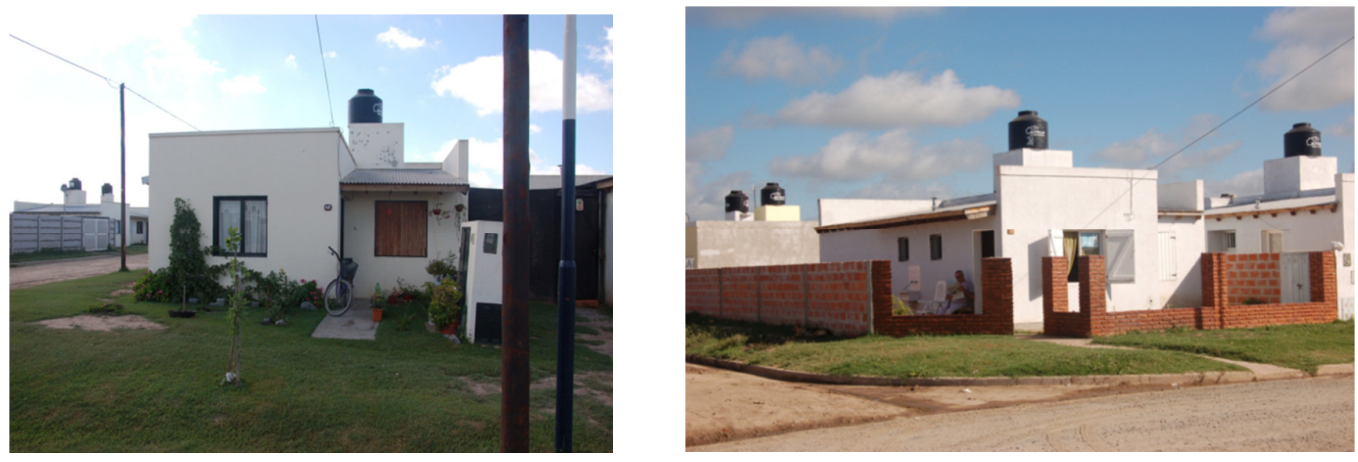

Federal con Municipios
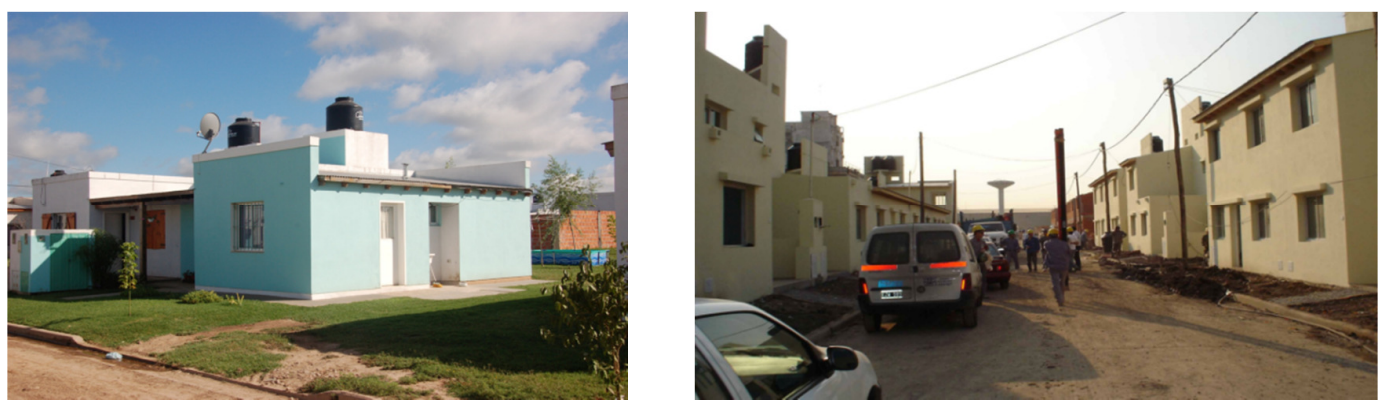

Federal Villas
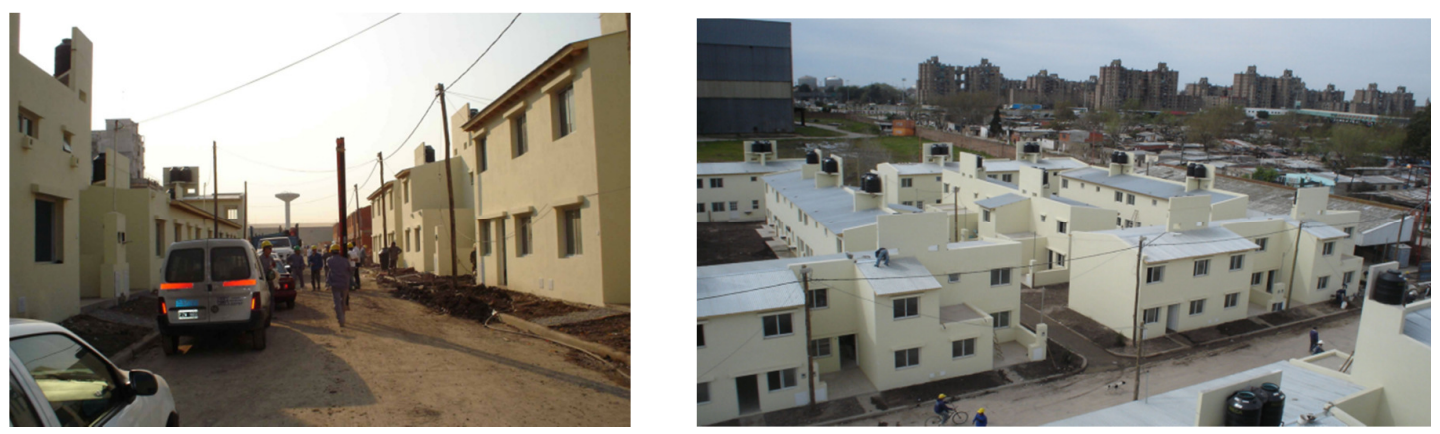

${ }^{15}$ Fotos pertenecientes a la Dirección de Política Habitacional del IVBA. 
Operatorias de Vivienda Provinciales (2003-2009) ${ }^{16}$

Compartir
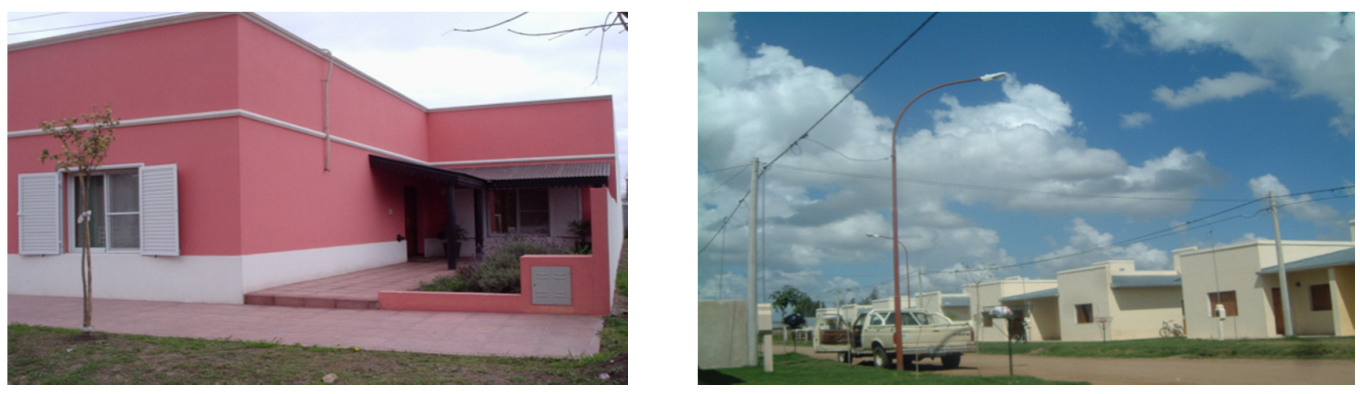

Policía Comunal
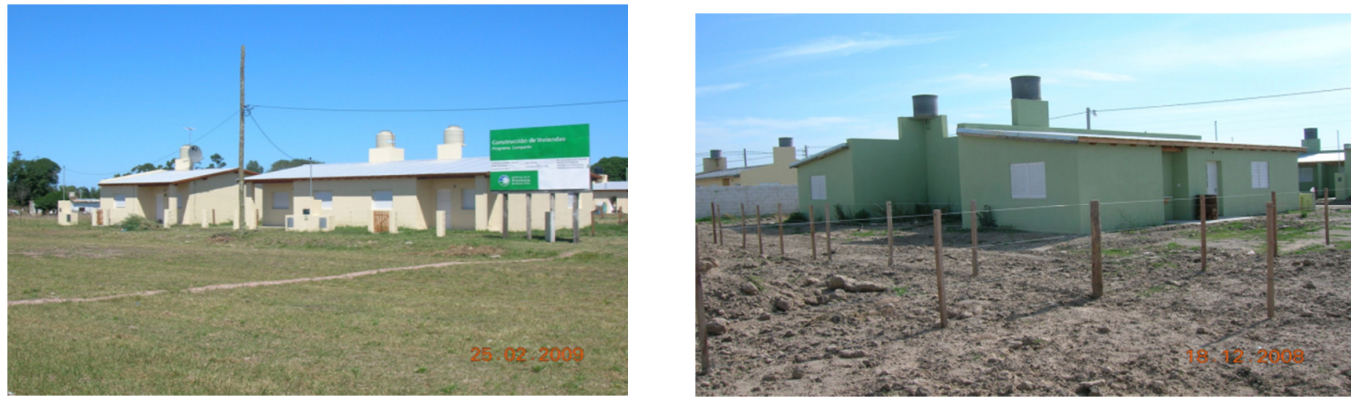

${ }^{16}$ Fotos pertenecientes a la Dirección de Política Habitacional del IVBA. 


\section{Bibliografía:}

Ballent, A. (2005). Las Huellas de la Política. Viviendas, ciudad, peronismo en Bs. As.1943-1955. Buenos Aires: Prometeo.

Bachelard, G. (2011). La Poética del Espacio. México: Fondo de Cultura Económica.

Borthagaray, J. (comp.). (2007). Habitar Buenos Aires, las manzanas, los lotes y las casas. Buenos Aires: Ediciones FADU.

Carballeda, A. J. M. (2006). El Trabajo Social desde una mirada histórica centrada en la intervención. Del orden de los cuerpos al estallido de la sociedad. Buenos Aires: Espacio Editorial.

Corbalán, M. A. (2002). El Banco Mundial intervención y disciplinamiento. El caso argentino, enseñanzas para América Latina. Buenos Aires: Biblos.

Danani, C. (1995). Algunas precisiones sobre la Política Social como campo de estudio y la noción de población-objeto. En Hintze S. (org.), Políticas Sociales contribuciones al debate teórico metodológico. Buenos Aires: Universidad de Buenos Aires.

Esping-Andersen, G. (1993). Los tres mundos del Estado de Bienestar. Valencia: Alfons el Magnánim.

Fernández Wagner, R. (2008). Democracia y ciudad. Buenos Aires: Universidad Nacional de Capitán Sarmiento.

Gutierrez, R. (2011). Una historia que es presente. La memoria como herramienta para dar respuestas adecuadas. En Radavanovic, E. y Balmaceda, C. (coord.), La Habitación Popular Bonaerense 1943-1955. Buenos Aires: Marcelo Kohan.

Iamamoto, M. (2008). Servicio Social en Tiempo de capital fetiche. San Pablo: Cortez Editora.

Lechner, N. (1984). Especificando la Política. En Vega, J. (coord.), Teoría y Política de América Latina. México: CIDE.

Marshall, T. H. (1992). Citizenship and social class. En T.H. Marshall and T. Bottomore, Citizenship and Social Class. Londres: Pluto Press.

Netto, J. P. (2009). La concretización de derechos en tiempos de barbarie. En Borgianni, E.; Montaño, C. (orgs.), Coyuntura actual, latinoamericana y mundial: Tendencias y movimientos. San Pablo: Cortez Editora.

Nun, L. (1987). La Teoría Política en la transición democrática. En Nun, J y Portantiero, J.C. (comp.), Ensayos sobre la transición democrática en Argentina. Buenos Aires: Puntosur.

Oszlak, O. y O’Donnell, G. (1976). Estado y Políticas Estatales en América Latina: hacia una estrategia de investigación. Buenos Aires: Mimeo. 
Pintos, P. y Naradowsky, P. (2012). La privatopía sacrílega. Efectos del urbanismo privado en los humedales de la cuenca baja del río Luján. Buenos Aires: Ediciones Imago Mundi,

Ortiz, E. (2002). Con los pies en la tierra. En Vivitos y coleando. México D.F.: HIC-al y Universidad Autónoma Metropolitana.

Rodulfo, M. B. (2006). Políticas Habitacionales en Argentina, Estrategias y Desafios. Buenos Aires: UBA.

Stewart, F. (1998). La Insuficiencia Crónica del Ajuste. En Bustelo, E. y Minujin A. (ed.), Todos Entran. Propuesta para Sociedades Incluyentes. Unicef: Santillana.

Svampa, M. (2005). La Sociedad Excluyente. Buenos Aires: Tourus.

Therborn, G. (1987). La ideología del poder y el poder de la ideología. España: Siglo XXI.

Tenti Fanfani, E. (1989). Estado y Pobreza: estrategias típicas de intervención. Buenos Aires: Centro Editor de América Latina.

Torrado, S. (1999). La Estructura Social Argentina. Buenos Aires: De la Flor.

Yujnovsky O. (1984). Claves políticas del problema habitacional argentino 1955-1981. Buenos Aires: Grupo Editor Latinoamericano.

\section{Publicaciones:}

Besada, R. y otros. (2008). Informe de Auditoría de Obras del Plan Federal. Buenos Aires: I.V.B.A.

Calello, T. (2000). Breve caracterización histórica de la Región Metropolitana de Bs. As. Buenos Aires: Universidad Nacional de General Sarmiento.

Cedrón. O. (2003). Taller de Hábitat, Trabajo y Desarrollo Social. CEVE -SEHAS. Buenos Aires: IVBA.

Cicolella, P. (1999). Globalización y dualización en la Región Metropolitana de Bs. As. Grandes inversiones y reestructuración socioterritorial en los años noventa. Santiago de Chile: Revista Eure $N^{\circ} 76$.

Clichevsky, N. (2010). Acceso a la Tierra Urbana y Políticas de Suelo en el Buenos Aires Metropolitano. Revista Iberoamericana de Urbanismo ${ }^{\circ} 9$.

Cobb, R.W. y Elder, C.D. (1983). Participation in American Politics: The Dynamics of Agenda-building. Baltimore: Johns Hopkins University Press.

Cortés, R. y Marshall, A. (1993). Política Social y regulación de la fuerza de trabajo. En cuadernos Médico-Sociales. N 65-66.Rosario: CESS. 
Cuenya, B. (1992). Políticas Habitacionales en la crisis: el caso de Argentina. Revista Panorama Internacional Vol.3, Nº3.

Fernández Wagner, R. (2006). Interrogantes sobre la sustentabilidad de la política habitacional Argentina. Seminario Iberoamericano de ciencia y tecnología para el hábitat popular. Córdoba.

Giménez, A. (1986). Poder, Estado y Discurso. México: UNAM.

Golbert, L. (2004). Notas sobre la historiografía de la política social en Argentina. En, El país del no me acuerdo. Buenos Aires: Prometeo.

Igarzabal, M. E. (1999). Instituto de la Vivienda de la Provincia de Bs. As. Memoria 1956-1999. Buenos Aires: IVBA.

Lombardo, J.D. (1999). Pensamiento urbanístico y desarrollo urbano en la Región Metropolitana de Bs. As. Informe de Investigación Nº6. Buenos Aires: Universidad Nacional de General Sarmiento.

López, E. (2000). La construcción de la vivienda como proceso de construcción de ciudadanía: Una perspectiva histórica. San Pablo: Pontificia Universidad Católica de López, E. (2002). Politicas habitacionales e intervención social. Buenos Aires: Revista Margen $\mathrm{N}^{\circ} 26$.

López, E. (2010). Ficha de cátedra de Trabajo Social I. Buenos Aires: FTS-UNLP.

López, E. (2013). Informe del Programa Buenos Aires Hogar. Buenos Aires: FTSUNLP.

Manes, R. (2012). La Política Habitacional en la Provincia de Bs. As. Tensiones en la efectivización del derecho a la Vivienda. Trabajo Final de la Especialización en Políticas Sociales. Buenos Aires. FTS-UNLP.

Ozlak, O. (1983). Los sectores populares y el derecho al espacio urbano. Buenos Aires: Revista Punto de vista. FSC. UBA.

Pelli, V. (1994). Autoconstrucción: El Camino hacia la Gestión Participativa y Concertada del Hábitat. Resistencia.

Perkins, N. y otras (2007). Evaluación de la Aplicación de los programas Plan Federal Construcción Nueva, Mejor Vivir y Subprogramas de Urbanización de Villas y Asentamientos Precarios. Operatoria llave en mano. Buenos Aires: I.V.B.A.

Pirez, P. (1994). Buenos Aires Metropolitana. Política y Gestión de la Ciudad. Buenos Aires: Centro Editor de América Latina.

Reese, E. (2012). Disertación sobre Hábitat Popular y Políticas Públicas. Buenos Aires: FTS-UNLP.

Sojo, C. (2002). La noción de ciudadanía en el debate Latinoamericano. Revista de la Cepal N०76. 
Torres, H. (1993). El Mapa Social de Bs. As. (1940-1990). Buenos Aires: Dirección de Investigaciones- Secretaría de Investigación y Posgrado. FADU. UBA

Zambrini, E. (2010). Políticas Sociales y Estructura Social Argentina. Carrera de Especialización en Políticas Sociales. Buenos Aires: FTS. UNLP.

Zambrini, E. y Gabrinetti, M. (2011). Políticas Sociales en Argentina de la Sociedad de Beneficencia a la Asignación Universal por hijo. Aportes para el análisis desde una perspectiva histórica. Buenos Aires: Revista Escenarios $\mathrm{N}^{\circ} 16$.

\section{Páginas de Internet Consultadas:}

Aboy, R. La Vivienda Social en Buenos Aires en la Segunda Posguerra. Scripta Nova Revista Electrónica de Geografía ay Ciencias Sociales de la Universidad de Barcelona. Recuperado de http://www.ub.edu/geocrit/nova.htm

Aparicio, S. (2010). La ciudad viva. Recuperado de http://www.laciudadviva.org

Declaración Universal de los Derechos Humanos. Recuperado de http://www.un.org/es/universal-declaration-human-rights

Harvey, D. (2008). El derecho a la ciudad. Recuperado de http://es.scribd.com/doc/16303284/Harvey-David-El-derecho-a-la-ciudad-NLR-n-53$\underline{2008}$

Instituto Nacional de Estadísticas y Censos de la República Argentina. Recuperado de http://www.indec.mecon.ar

Instituto de la Vivienda de la Provincia de Bs.As. Recuperado de http://vivienda.mosp.gba.gov.ar

Ley N $N^{0}$ 24430. Constitución Nacional de la República Argentina. Boletín Oficial de la República Argentina, 3 de enero de 1995. Recuperado de http://servicios.infoleg.gob.ar/infolegInternet/anexos/0-4999/804/norma.htm.

Ley $N^{0}$ 22740. Constitución de la Provincia de Buenos Aires. Boletín Oficial de la República Argentina, 13 de septiembre de 1994. Recuperado de http://www.infoleg.gob.ar/?page_id=173.

Mangada, E. (2008). Ciudad Compacta-Ciudad Dispersa. Revista Iberoamericana de Sostenibilidad.Recuperadodehttp://www.otromundoesposible.net/seccioneshistoricas/mi radas-urbanas/ciudad-compacta-ciudad-dispersa 
Mathivet, Ch. (2009). El derecho a la ciudad: claves para entender la propuesta de crear. Otra ciudad posible. Recuperado de http://base.d-p-h.info/es/fiches/dph/fichedph-8034.html

Molteni, J. y Galcerán, V. (2011). Las obras públicas en la Provincia de Bs As durante el Gobierno de Domingo Mercante (1946-1952), en $2^{\circ}$ Congreso de la Red de Estudios sobre el Peronismo. Recuperado de http://redesperonismo.com.ar

Pacto Internacional de Derechos Sociales, Económicos y Culturales. Recuperado de http://www.ohchr.org/SP/ProfessionalInterest/Pages/CESCR.aspx

Observación General N4 del Comité de Derechos Sociales, Económicos y Culturales. Recuperadodehttps://confdts1.unog.ch/1\%20SPA/Tradutek/Derechos_hum_Base/CESC R/00_1_obs_grales_Cte\%20Dchos\%20Ec\%20Soc\%20Cult.html 
